New Mexico Bureau of Mines \& Mineral Resources

A DIVISION OF

NEW MEXICO INSTITUTE OF MINING \& TECHNOLOGY

\title{
Geology and geothermal waters of Lightning Dock region, Animas Valley and Pyramid Mountains, Hidalgo County, New Mexico
}

\author{
by Wolfgang E. Elston, Edmond G. Deal, and Mark J. Logsdon
}




\section{DISCLAIMER}

This report was prepared as an account of work sponsored by an agency of the United States Government. Neither the United States Government nor any agency Thereof, nor any of their employees, makes any warranty, express or implied, or assumes any legal liability or responsibility for the accuracy, completeness, or usefulness of any information, apparatus, product, or process disclosed, or represents that its use would not infringe privately owned rights. Reference herein to any specific commercial product, process, or service by trade name, trademark, manufacturer, or otherwise does not necessarily constitute or imply its endorsement, recommendation, or favoring by the United States Government or any agency thereof. The views and opinions of authors expressed herein do not necessarily state or reflect those of the United States Government or any agency thereof. 


\section{DISCLAIMER}

Portions of this document may be illegible in electronic image products. Images are produced from the best available original document. 
NEW MEXICO INSTITUTE OF MINING \& TECHNOLOGY

Charles R. Holmes, Acting President

NEW MEXICO BUREAU OF MINES \& MINERAL RESOURCES

Frank E. Kơrriowski, Director

George S. Austin. Deputy Director

\section{BOARD OF REGENTS}

Ex Officio

Toney Anaya, Governor of New Mexico

Leonard DeLayo, Superintendent of Public Instruction

Appointed

Steve Torres, President, 1967-1985, Socorro

Dave Rice, Secretary-Treasurer, 1978-1983, Carlsbad

William G. Abbott, 1961-1985, Hobbs

Judy Floyd, 1977-1987, Las Cruces

Owen Lopez, 1977-1983, Santa Fe

\section{BUREAU STAFF}

Full Time

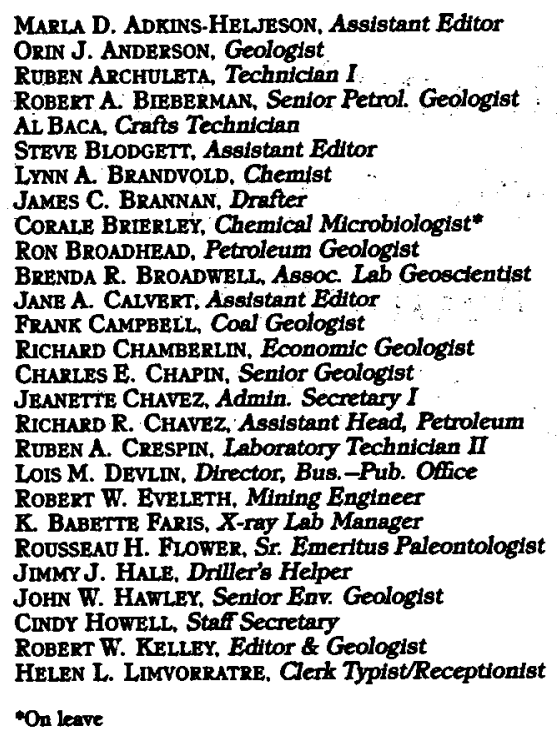

ARLEEN LINDSEY, Staff Secretary DAvid W. LoVE. Environmental Geologist Wess Mauldin, Driller

VIRGinu MCLEMore. Geologist

LYNNE MCNEIL. Staff Secretary

Norma J. Meris, Department Secretary David Menzie, Geologist

TeResa MUELler. Drafter

Robert M. NorTH, Mineralogist

KeITH O'Brien, Hydrologist

JoANne C. OsBurn, Coal Geologist .

GLeNN R: OsBuRN, Volcanologist

Barbara R. POPP, Lab Blotechnologist

MARShall A. REITER, Senior Geophysictst

JACQUES R. RENaULT, Senior Geologist

JAMES M. Robertson. Mining Gieologist

Gretchen H. Rorbal, Coal Geologist .

ROBERT SANFORD, Laboratory Assistant

DEBORAy A. SHAw, Editorial Techniclan

WrLliam J. STONE, Hydrogeologist

SAmuel Thompson III, Senior Petrol. Geologist

JUDY M. VAIZA, Executive Secretary

Debra VetTerman, Drafter

Robert H. Weber. Senior Geologist

Donald Wolberg. Vertebrate Paleontologist

Russell WoOd Draftsman

Michaet W. WOOLDRIDGE. Chief Sct. Ilustrator

Part Time

Christina L. Balk, Geologist

howard B. Nickelson, Coal Geologist

Beverty OHLnNe. Acting Director, Info. Services Thomas E. Zimmerman. Chief Security Officer

Graduate Students

Brian Arkell

DanNy Bobrow

JAMES T. BOYLE

LEE BROUILLARD

Steven M. Cather

Gerry W. Clarkson

DAvid R. Guninger

TERRY JENSEN

Dodglas L. Heath

ADRIAN HUNT

INGRID KLICH

IONE LNDIEY
Richard P. Loznsxy

Patricu L. PerRy

STEVEN ROSEN

JOHN M. WAKEFIELD

MARY LYNNE YATES

Plus about 50 undergraduate assistants

First Printing, 1983

Published by Authority of State of New Mexico, NMSA 1953 Sec. 63-14

Printed by University of New Mexico Printing Plant, April 1983

Available from New Mexico Bureau of Mines \& Mineral Resources, Socorro, NM 87801 
This circular consists of three chapters. The lead chapter on Geology, by E. G. Deal and W. E. Elston, describes the geology of the Lightning Dock Known Geothermal Resources Area (KGRA) and nearby parts of the Pyramid Mountains and Animas Valley, Hidalgo County, New Mexico (geologic map in back pocket; fig. 1). The geologic mapping done during the summers of 1975 and 1976 and covering four 71/2-min quadrangles (Pyramid Peak, Swallow Fork Peak, Table Top Mountain, and South Pyramid Peak) delineates aspects of regional geology that bear on the interpretation of the Lightning Dock geothermal anomaly. More detailed reports on regional geology have been published elsewhere (Deal and others, 1978; Elston and others, 1979).

The chapter on Geochemistry, by M. J. Logsdon, summarizes an M.S. thesis on the thermal and cold waters of part of the Animas Valley completed by the author at the University of New Mexico during 19781980 (Logsdon, 1981). The thesis should be consulted for details of procedures, including computer programs, mineral-stability diagrams, and the analytical procedures for determining the isotopes of oxygen and hydrogen.

The closing chapter on Conclusions concerning geothermal resources, by all three authors, summarizes the features of the geothermal system known or inferred at present.

This project was supported by U.S. Geological Survey Geothermal Program grants 14-08-001-G-255, -348 , and -630 and New Mexico Energy and Minerals Department grants 75-109, 75-117, 76-264, 78-2123, and 68-R2102. In the report's final stages, additional support came from National Science Foundation grants EAR 77-24501 and EAR-80-07836. The main purpose was assessment of geothermal potential of the Lightning Dock KGRA; a secondary purpose was delineation of volcanic centers that would be detrimental to oil and gas accumulation. The geothermal aspects of our study were part of a larger project by eight co-investigators, seven from the University of New Mexico and one from New Mexico State University, that covered much of the Rio Grande valley and Basin and Range regions of New Mexico. Results have been summarized by Callender (1981). Our work on the Lightning Dock KGRA was done in cooperation with geophysical surveys by $G$. $R$. Jiracek and associates (University of New Mexico); the results have been summarized elsewhere (Jiracek and Smith, 1976; Smith, 1978; Jiracek, in Callender, 1981). In general, geological and geophysical interpretations are compatible. Water samples for chapter II of this cir-

cular were kindly furnished by C. A. Swanberg (New Mexico State University), who had collected them as part of a regional geochemical study to determine reservoir base temperatures (Swanberg, 1978).

Major-element chemical analyses of volcanic rocks were made at the University of New Mexico by Gayle Lux, supervised by John Husler, using atomic-absorption spectrophotometry and wet-chemical techniques. Unless attributed to other sources, the K-Ar dates cited in this circular were determined by P. E. Damon and Muhammad Shafiqullah (University of Arizona) under NSF grant EAR 76-02590. Sample localities and analytical data were listed by Deal and others (1978). All dates conform to the 1976 IUGS standards for decay and abundance of ${ }^{40} \mathrm{~K}$ (Dalrymple, 1979).

ACKNOWLEDGMENTS-Special thanks are due to G. P. Landis (formerly University of New Mexico, now U.S. Geological Survey), who instigated and supervised Logsdon's geochemical study (chapter II of this circular), determined the isotopic composition of hydrogen of water from the Animas Valley, and also supervised the studies of fluid inclusions in fluorite crystals by $\mathbf{E}$. E. Erb (then University of New Mexico, now Chevron Resources) and T. J. Bornhorst (then University of New Mexico, now Michigan Technological University).

H. D. Holland (Harvard University), R. O. Fournier (U.S. Geological Survey), and C. J. Yapp (University of New Mexico) gave valuable advice on the interpretation of geochemical data from ground-water samples. S. G. Wells (University of New Mexico) wrote the section of this circular dealing with Quaternary deposits. We benefited greatly from discussions with C. W. Thorman and Harald Drewes (U.S. Geological Survey), who mapped the geology of a large part of northern Hidalgo County, including the two $71 / 2-$ min quadrangles immediately north of the area covered by this circular (Thorman and Drewes, 1978). The geologic map was drafted by Bernice Swenson and Judith Salas, University of New Mexico.

\begin{tabular}{|c|c|}
\hline \multirow{2}{*}{$\begin{array}{l}\text { Albuquerque and Socorro, } \\
\text { New Mexico, } \\
\text { Tucson, Arizona, } \\
\text { September } 1981\end{array}$} & $\begin{array}{r}\text { Wolfgang } E \text {. Elston, } \\
\text { Professor of Geology, } \\
\text { University of New Mexico }\end{array}$ \\
\hline & $\begin{array}{r}\text { Edmond G. Deal, Geologist, } \\
\text { Duval Corporation }\end{array}$ \\
\hline & $\begin{array}{r}\text { Mark J. Logsdon, } \\
\text { Industrial Minerals Geologist } \\
\text { New Mexico Bureau of Mines } \\
\text { \& Mineral Resources }\end{array}$ \\
\hline
\end{tabular}

Albuquerque and Socorro, New Mexico Tucson, Arizona, September 1981

\author{
Edmond G. Deal, Geologist, \\ Duval Corporation \\ \& Mineral Resources
}




\title{
Contents
}

\author{
ABSTRACT 7 \\ INTRODUCTION 7 \\ GEOLOGY 9 \\ STRATIGRAPHY 9 \\ Pre-cauldron rocks 9 \\ Rocks of Muir cauldron, Pyramid Mountains volcanic \\ complex 10 \\ Post-cauldron rocks 14 \\ Rocks of Animas Valley 16 \\ Regional correlation 17 \\ INTRUSIVE ROCKS 17 \\ GEOLOGIC STRUCTURE 17 \\ Pre-Oligocene structures 17 \\ Oligocene structures 17 \\ Post-Oligocene structures 21 \\ Other possible subsurface structures of \\ Animas Valley 21 \\ REGIONAL DISTRIBUTION OF BASALT YOUNGER THAN \\ 7 M.Y. 21 \\ Mineralization 21 \\ GEOLOGICAL AND GEOPHYSICAL CHARACTERISTICS OF \\ LIGHTNING DOCK KGRA 22 \\ Evidence against post-Oligocene rhyolite 23 \\ Age of hydrothermal alteration 23 \\ Hydrothermal veins and extinct hot springs 23 \\ Geophysical evidence for structural control 24 \\ Seismicity and heat flow 25 \\ CURRENT DEVELOPMENT OF GEOTHERMAL \\ RESOURCES 26 \\ GEOCHEMISTRY 26 \\ WATER CHEMISTRY 26 \\ Chemical composition 26 \\ Isotopic composition 26 \\ Estimates of reservoir temperatures 31 \\ Water-mineral interactions $\mathbf{3 1}$ \\ Structural control and flow of thermal waters $\mathbf{3 3}$ \\ Mixing model 34 \\ GEOTHERMAL RESERVOIR 35 \\ Physicochemical environment 35 \\ Calculated alteration phases 37 \\ Geometry and hydrodynamics of geothermal system $\mathbf{3 8}$ \\ CONCLUSIONS ON GEOCHEMISTRY 39 \\ CONCLUSIONS CONCERNING GEOTHERMAL \\ RESOURCES 41 \\ PROPOSED GEOTHERMAL SYSTEM 41 \\ VOLUME OF GEOTHERMAL RESERVOIR 41 \\ FUTURE PROSPECTS 41 \\ REGIONAL CONSIDERATIONS \\ 41

\section{REFERENCES 43} \\ POCKET inside back cover \\ GEOLOGIC MAP \\ TABLE 2-CHEMICAL DATA
}




\section{Tables}

1-Chemical analyses of volcanic rocks from Pyramid Mountains 10

2-Chemical data pocket

3-Comparison of calculated reservoir temperatures 28

4-Multiple linear regression-correlation coefficients 32

5-Minerals calculated by WATEQF to be in equilibrium with waters of lower Animas Valley 33

6-Mixing estimates and calculated reservoir chemistry 36

7-Physicochemical parameters 36

\section{Figures}

1-Location of Lightning Dock KGRA vi

2-Localities in Animas Valley and Pyramid Mountains 8

3-Distribution of rhyolite of Jose Placencia Canyon and tuff of Woodhaul Canyon 11

4-Distribution of tuff of Graham Well, latite of Uhl Well, and rhyolite of Pyramid Peak 12

5-Distribution of Rimrock Mountain Group 14

6-Tectonic map of southern Pyramid Mountains 18

7-Structural elements of Muir cauldron 20

8-Distribution of Pliocene-Pleistocene basalt and lowtemperature manganese and fluorspar veins $\mathbf{2 2}$

9-Ground-water temperatures 24

10-Temperatures 1 and $2 \mathrm{~m}$ below land surface 25

11-Locations of P-series and LD-series water samples 27

12-Locations of P-series and An-series water samples 27

13-Trilinear plot of water samples from Animas Valley 27

14- $\mathrm{Ca}-\mathrm{Mg}-\mathrm{Na}+\mathrm{K}$ and $\mathrm{HCO}_{3}-\mathrm{Cl}-\mathrm{SO}$, plots 29

$15-\delta D$ and $\delta^{18} O$ values for P-series waters 29

16 -Isopleths for $\delta^{\prime \prime} O$ values of P-series waters 31

17-Isopleths for best-estimate shallow reservoir temperatures 31

18-Isopleths for boron/calcium molar ratios 34

19-Isopleths for boron/sodium molar ratios 34

20-Isopleths for sulfate/fluoride molar ratios 34

21-Plot of dissolved silica versus enthalpy 35

22-Plots of $\left(\log a_{K} / \log a_{N^{+}}\right)$and $\left(\log a_{N_{2}} / / \log a_{H^{+}}\right)$ versus $\log \mathrm{a}_{\mathrm{H}_{4} \mathrm{SiO}_{4} \quad 37}$

23-Composition of low-temperature water samples 37

24-Compositions of hot-well samples and calculated geothermal reservoir waters for system $\mathrm{HCl}-\mathrm{H}_{2} \mathrm{O}-\mathrm{Al}_{2} \mathrm{O}_{3}$ $\mathrm{K}_{2} \mathrm{O}-\mathrm{Na}_{2} \mathrm{O}-\mathrm{SiO}_{2} \quad 37$

25-Compositions of hot-well samples and geothermal reservoir waters for system $\mathrm{HCl}-\mathrm{H}_{2} \mathrm{O}-\mathrm{Al}_{2} \mathrm{O}_{3}-\mathrm{MgO}-\mathrm{Na}_{2} \mathrm{O}$ $\mathrm{SiO}_{2} 38$

26-Schematic block diagram of geothermal system in lower Animas Valley 40 


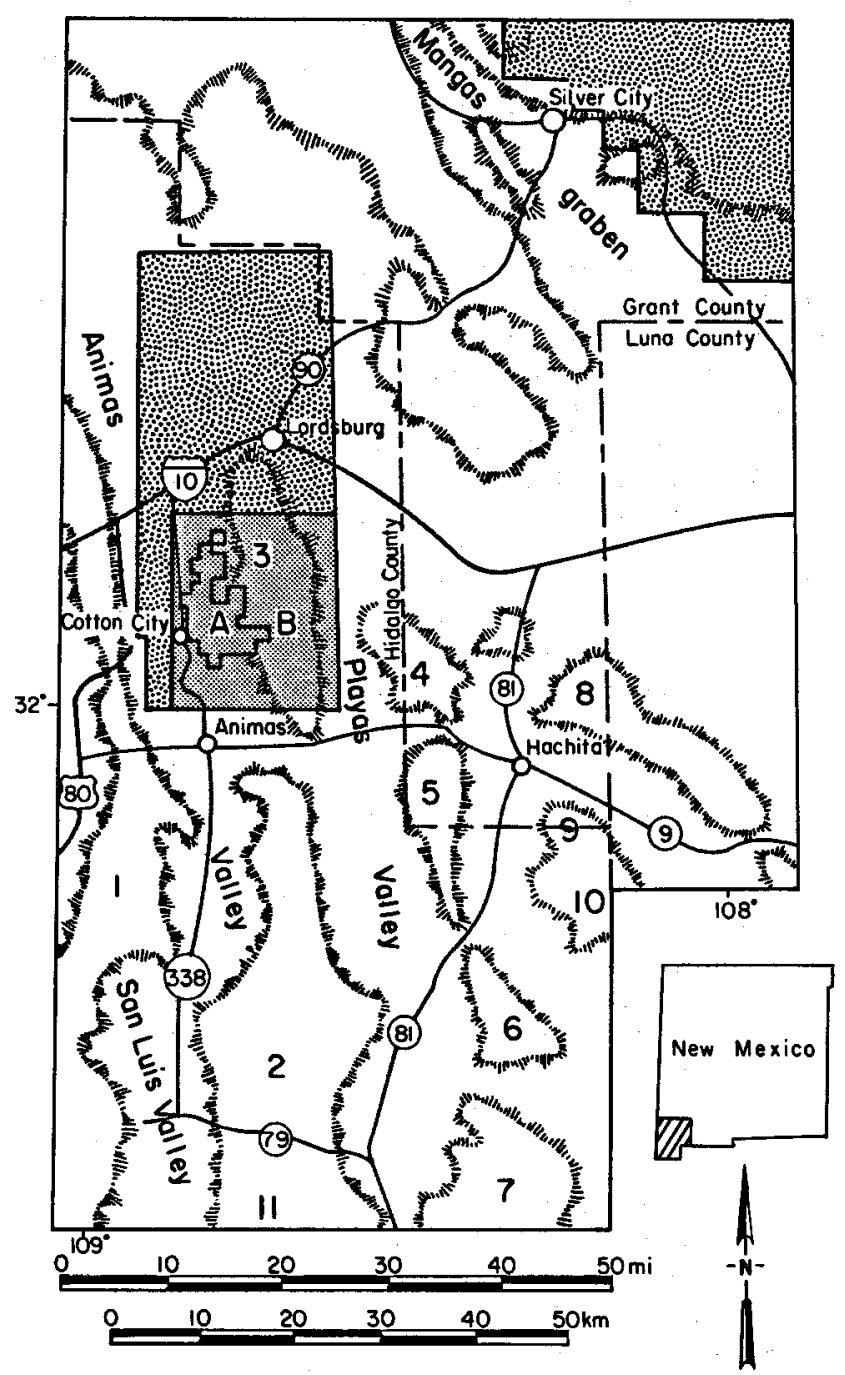

FIGURE 1-LOCATION OF LIGHINING DOCK KGRA; A) mapped area (coarsely stippled) and B) other "areas classified as being valuable prospectively for geothermal steam and associated geothermal resources" (finely stippled; Grim and others, 1977). 1-Peloncillo Mountains, 2-Animas Mountains, 3--Pyramid Mountains, 4 -Coyote Hills, 5-Little Hatchet Mountains, 6-Big Hatchet Mountains, 7-Alamo Hueco and Dog Mountains, 8-Cedar Mountains, 9-Apache Hills, and 10- Sierra Rica. 


\begin{abstract}
This circular covers the geology of the Pyramid Peak, Swallow Fork Peak, Table Top Mountain, and South Pyramid Peak 71/2-min quadrangles, which include the Lightning Dock KGRA. Hot wells $\left(70-115.5^{\circ} \mathrm{C}\right)$ seem to be structurally controlled by intersections of the ring-fracture zone of an Oligocene ash-flow tuff cauldron (Muir cauldron), a Miocene-to-Holocene north-trending basin-and-range fault (Animas Valley fault), and a northeast-trending lineament that appears to control anomalously heated underground waters and Pliocene-Pleistocene basalt cones in the San Bernardino, San Simon, and Animas Valleys. The Muir cauldron, approximately $20 \mathrm{~km}$ in diameter, collapsed in two stages, each associated with the eruption of a rhyolite ash-flow-tuff sheet and of ringfracture domes. Most of the hydrothermal alteration of the Lightning Dock KGRA is related to the first stage of eruption and collapse, not to the modern geothermal system. Contrary to previous reports, no silicic volcanic rocks younger than basin-and-range faulting are known; unconformities beneath rhyolite ring-fracture domes are caused by Oligocene caldera collapse, not by basin-and-range faulting. The Animas Valley is the site of widespread post-20 m.y. travertine deposits and near-surface veins of calcite, fluorite, and/or psilomelane, controlled by north- or northwest-trending basin-and-range faults. The fluoride-bearing waters of the Lightning Dock KGRA may be a late stage of this hydrothermal activity. Distribution of Pliocene-Pleistocene basalt suggests that deepseated basalt near the solidus may be the ultimate heat source.
\end{abstract}

\title{
Introduction
}

In 1948 , boiling water at $115.5^{\circ} \mathrm{C}\left(240^{\circ} \mathrm{F}\right)$ and a rock described as hot rhyolite were encountered at $26.5 \mathrm{~m}$ (87 $\mathrm{ft}$ ) in a water well being drilled in the Animas Valley, in NE $1 / 4$ sec. 7, T. 25 S., R. 19 W., Hidalgo County, New Mexico (Kintzinger, 1956). Since then, several more wells have been drilled. Their locations, shown on the U.S. Geological Survey Swallow Fork Peak 71/2-min quadrangle, are in the southwest corner of New Mexico, approximately $25 \mathrm{~km}$ (15 mi) southwest of Lordsburg. The nearest settlement is Cotton City, about $7.5 \mathrm{~km} \mathrm{(4.5}$ $\mathrm{mi})$ to the southwest. The well site is directly behind the house of the present owner, Thomas McCants of Cotton City. It can be reached by a graded road from $\mathrm{NM}-338,4.5 \mathrm{~km}(2.7 \mathrm{mi})$ to the west (fig. 1).

The Animas Valley is typical of the Basin and Range province. Its interior drainage leads to two playa lakes, remnants of Pleistocene Lake Animas which once was

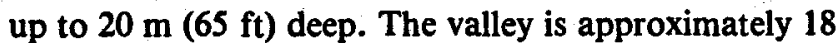
$\mathrm{km}(12 \mathrm{mi})$ wide; the hot wells are $5 \mathrm{~km}(3 \mathrm{mi})$ from its eastern edge. To the west, the valley is bordered by the Peloncillo Mountains and to the east by the Pyramid and Animas Mountains. Compared to other ranges in the region, the Pyramid Mountains are low and deeply eroded; their highest point, Pyramid Peak, elevation $1,830 \mathrm{~m}(6,002 \mathrm{ft})$, stands approximately $566 \mathrm{~m}(1,857$ $\mathrm{ft}$ ) above the floor of the nearest playa (fig. 2). Annual precipitation at Lordsburg is about $240 \mathrm{~mm}$ (9.5 inches) and natural vegetation is sparse.

Since 1950, much of the Animas Valley has been irrigated for growing cotton, sorghum, pecans, and other crops. Geothermal water and steam are being used for heating greenhouses. The nearest town is Lordsburg; the nearest industrial plant is the Phelps Dodge Cor- poration Hidalgo Smelter at Playas, New Mexico, approximately $40 \mathrm{~km}(25 \mathrm{mi})$ to the southeast.

PREVIOUS WORK-Previous publications on the geology of the Playas Valley include hydrologic reports by Schwennensen (1918), Spiegel (1957), Reeder (1957), and Landsford and others (1981). A geomorphic study of the valley north of the hot wells was made by Fleischhauer (1978). That study has been extended south, to cover the hot-well field, by Stephen G. Wells, University of New Mexico, as part of the present study.

The geology of the part of the Peloncillo Mountains directly west of the hot wells was covered by Quaide (1953), Gillerman (1958), Armstrong and others (1978), and Drewes and Thorman (1980a, b). The geology of the Pyramid Mountains to the east was covered by Flege (1959); the present report is a complete revision of Flege's work. The Lordsburg mining district, which adjoins our map area to the north, was mapped by Lasky (1938), Flege (1959), Elston (1963), Clark (1970), and Thorman and Drewes (1978). The Cenozoic volcanic geology of Hidalgo County was summarized by Deal and others (1978).

The geothermal anomaly was first described by Kintzinger (1956) and mentioned later by Summers (1965a, b, c, 1970, 1972), Summers and others (1969), and Dellechaie (1977). Renner and others (1975) identified it as one of only two known hot-water convection systems in New Mexico in which indicated subsurface temperatures exceed $115^{\circ} \mathrm{C}\left(300^{\circ} \mathrm{F}\right.$; the Valles caldera in the Jemez Mountains is the other). Landsford and others (1981) appraised the economic potential of the Lightning Dock KGRA for greenhouses and for precooking beef. 


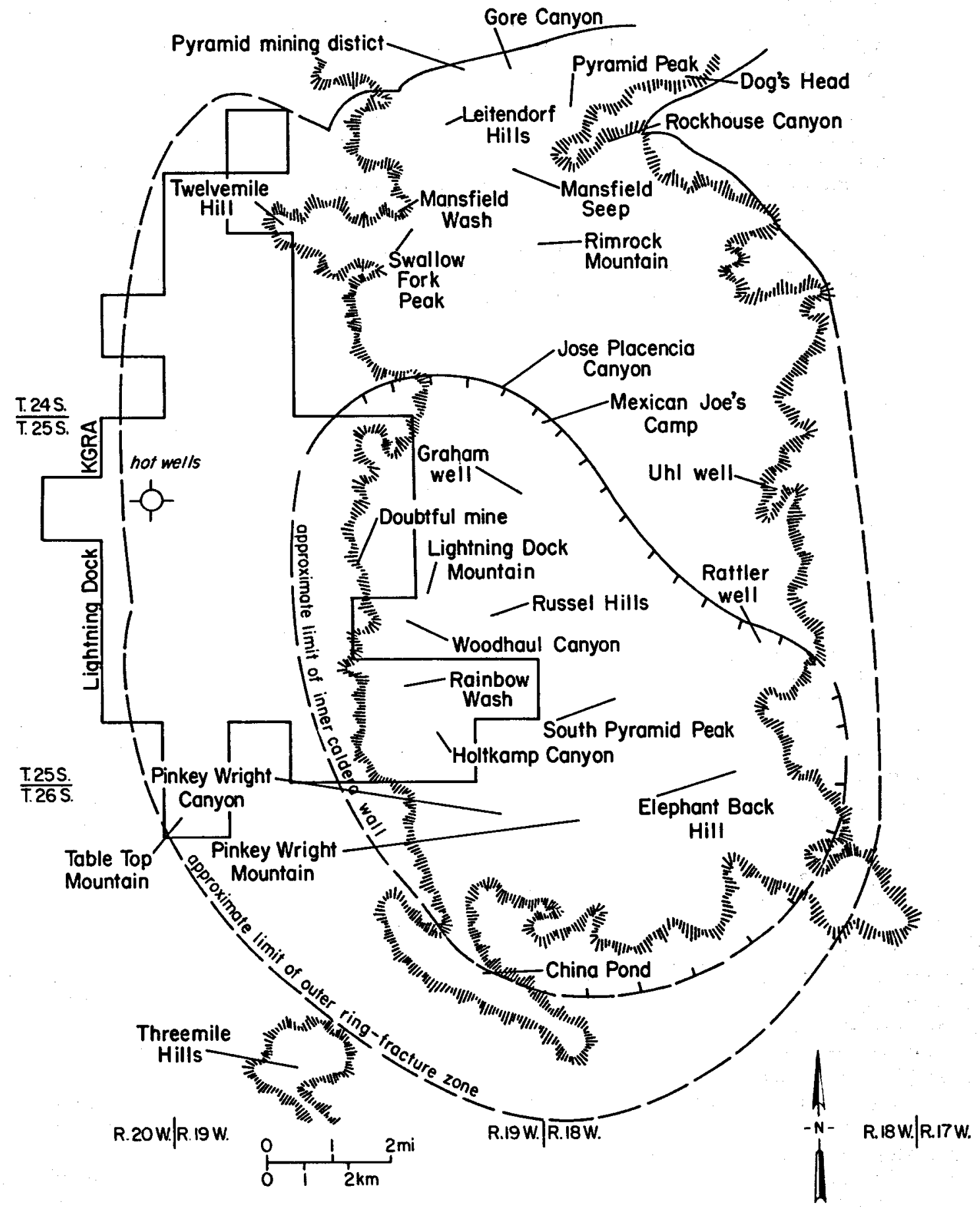

FIGURE 2-LOCALTIES IN ANIMAS VALLeY and PYramid Mountans MENTIONED IN TEXT; heavy line outlines Lightning Dock KGRA. 


\section{Geology}

Work over the last two decades has shown that midTertiary geologic events in southwestern New Mexico were dominated by volcanism, especially by the eruption of voluminous ash-flow tuff (ignimbrites) from enormous calderas (Elston, 1978; Deal and others, 1978). These have now been deeply eroded, so that few remnants of caldera topography remain. Instead, deeply eroded cauldron structures are exposed. The term caldera, as defined by Williams (1941), is essentially topographic, to describe a volcanic depression many times greater in diameter than any included vent or vents. The term cauldron, as defined by Smith and Bailey (1968), is essentially structural, to describe "all volcanic subsidence structures regardless of shape or size, or depth of erosion, or connection with surface volcanism."

The Pyramid Mountains are no exception to the prevalence of cauldrons. We have interpreted the southern two-thirds as a segment of an Oligocene ash-flow-tuff cauldron, elongated to the northwest. The name Muir cauldron, introduced by Deal and others (1978), is derived from the pioneer Muir Ranch. The Muir cauldron is too old to be considered a heat source for the Lightning Dock KGRA, but the modern geothermal anomaly seems partly to be structurally controlled by the intersection of its ring-fracture zone with the Animas Valley fault, a basin-and-range fault that was still active in Holocene time. Hydrothermal alteration is widespread in the Pyramid Mountain section of the Lightning Dock KGRA but is probably related to the Muir cauldron, not to the modern geothermal anomaly. Contrary to previous investigators, we found no evidence for post-Oligocene rhyolitic volcanism. We did find evidence for widespread fault-controlled hot-spring activity within the past 20 m.y.; the modern geothermal anomaly may be a relict. Quaternary basaltic volcanism is more widespread in the region than was previously supposed.

\section{Stratigraphy}

The stratigraphy of the southern part of the Pyramid Mountains is best defined in terms of the development of the Muir cauldron. Precauldron rocks consist of isolated exposures of Pennsylvanian(?) and Cretaceous sedimentary rocks, late Cretaceous and/or early Tertiary basalt and andesite, and Oligocene andesite. The felsic rocks of the cauldron have been included in the Oligocene Pyramid Mountains volcanic complex, which formed in two stages. A later group of Oligocene-early Miocene(?) post-cauldron ash-flow tuffs and basaltic flows has been designated as the Rimrock Mountain group. The ash-flow tuffs of the Rimrock Mountain group originated beyond the Pyramid Mountains, some from centers in the Animas Mountains to the south (Deal and others, 1978) and others from unknown sources. In general, the volcanic rocks of the Pyramid Mountains have calc-alkalic affinities. Rhyolite ashflow tuffs, lava flows, and breccias are the most abundant rock types.
Valley-fill sediments, deposited during basin-andrange faulting, are the youngest rocks of the region.

\section{Pre-cauldron rocks}

PALEOZOIC AND MESOZOIC SEDIMENTARY ROCKSIn many places, Paleozoic and Mesozoic sedimentary rocks occur as exotic blocks in volcanic rocks of the Pyramid Mountains volcanic complex. They appear in situ only in the southwest part of the map area-in the Threemile Hills and in isolated hills northwest of them. A hill in NW1/4 sec. 19, T. 26 S., R. 19 W. consists of fusulinid-bearing limestone, tentatively identified as part of the Horquilla formation (Pennsylvanian). A small patch of pelecypod-bearing limestone astride the Old Animas Road, in NW 1/4 sec. 28, T. 26 S., R. 19 W., is tentatively assigned to the U-Bar Formation (Lower Cretaceous). Small patches of quartz sandstone in the Threemile Hills, also in sec. 28, T. 26 S., R. 19 W., may be part of the Mojado Formation (Lower Cretaceous).

CRETACEOUS OR EARLY TERTIARY BASALT AND ANDESITE-Propylitized basaltic andesite and andesite form the bedrock of much of the Lordsburg mining district. Two members can be recognized, locally separated by up to $3 \mathrm{~m}$ ( $10 \mathrm{ft}$ ) of volcaniclastic sandstone and breccia. The aphanitic older member, named andesite of Shakespeare by Thorman and Drewes (1978), consists of felty andesine crystals, secondary calcite, and iron oxides that replace clinopyroxene and hornblende. The porphyritic younger member, named andesite of Gore Canyon by Thorman and Drewes (1978), has phenocrysts of andesine up to $3 \mathrm{~mm}$ ( 0.1 inches) long in a finegrained matrix of andesine, clinopyroxene, olivine, and hornblende. Both members include zones of epiclastic rocks. In the Gary quadrangle, the andesite of Shakespeare lies on Cretaceous sandstone (Thorman and Drewes, 1978), probably the Mojado Formation (Lower Cretaceous).

The chemical compositions of the aphanitic and porphyritic members are similar (table 1 , columns 1 and 2), and both have been pervasively propylitized. Their high contents of $\mathrm{H}_{2} \mathrm{O}$ and $\mathrm{CO}_{2}$ reflect the degree of alteration, which makes the rocks difficult to classify. The high contents also could account for an apparent reversal of radiometric ages. C. W. Naeser, cited by Marvin and others (1978) and by Thorman and Drewes (1978), determined zircon fission-track dates of $54 \pm 2.2 \mathrm{~m}$.y. for the andesite of Shakespeare and 67.3 $\pm 7.1 \mathrm{~m} . \mathrm{y}$ for the andesite of Gore Canyon. The apparent reversal of ages may have been caused by reheating of the andesite of Shakespeare. The dated samples were collected by C. H. Thorman in a mineralized area east of the outcrop of the Lordsburg granodiorite porphyry stock; buried extensions of the stock may be present beneath the sample sites. Biotite from the stock has yielded $\mathrm{K}-\mathrm{Ar}$ dates of $56.5 \pm 1.2 \mathrm{~m} . y$. (Deal and others, 1978) and $58.5 \pm 2.0 \mathrm{~m} . \mathrm{y}$. (Marvin and others, 1978).

ANDESITE OF HOLTKAMP CANYON-The andesite of Holtkamp Canyon forms the basement for the Pyramid Mountains volcanic complex throughout the southern 
TABLE 1-Chemical ANalyses (IN PERCENTS) OF volCanic rocks from Pyramid Mountans; analyst: Gayle Lux, University of New Mexico.

\begin{tabular}{|c|c|c|c|c|c|c|c|c|c|}
\hline Sample Number & 1 & 2 & 3 & 4 & 5 & 6 & 7 & B & 8 \\
\hline $\begin{array}{l}\mathrm{SiO}_{2} \\
\mathrm{Al}_{2} \mathrm{O}_{3} \\
\mathrm{Fe}_{2} \mathrm{O}_{3} \\
\mathrm{FeO} \\
\mathrm{MgO} \\
\mathrm{CaO} \\
\mathrm{Na}_{2} \mathrm{O} \\
\mathrm{K}_{2} \mathrm{O} \\
\mathrm{H}_{2} \mathrm{O}+\left(+\mathrm{CO}_{2}\right) \\
\mathrm{H}_{2} \mathrm{O}- \\
\mathrm{TiO}_{2} \\
\mathrm{P}_{2} \mathrm{O}_{3} \\
\mathrm{MnO} \\
\mathrm{SrO}\end{array}$ & $\begin{array}{l}51.78 \\
14.5 \\
7.11 \\
.42 \\
3.00 \\
7.05 \\
4.10 \\
1.98 \\
7.50 \\
.49 \\
1.15 \\
.61 \\
.111 \\
.031\end{array}$ & $\begin{array}{r}50.77 \\
14.25 \\
6.78 \\
.55 \\
2.94 \\
6.90 \\
4.12 \\
2.05 \\
7.56 \\
.59 \\
1.20 \\
.635 \\
.115 \\
.025\end{array}$ & $\begin{array}{c}58.96 \\
16.00 \\
3.21 \\
2.24 \\
1.80 \\
5.15 \\
3.72 \\
2.36 \\
3.96 \\
.415 \\
.90 \\
.225 \\
.072 \\
.044\end{array}$ & $\begin{array}{c}73.59 \\
12.75 \\
1.64 \\
.18 \\
.36 \\
.38 \\
3.70 \\
4.74 \\
1.20 \\
.67 \\
.28 \\
.065 \\
.011 \\
.0065\end{array}$ & $\begin{array}{c}68.87 \\
15.25 \\
2.73 \\
.24 \\
.47 \\
1.85 \\
4.25 \\
4.70 \\
.67 \\
.219 \\
.57 \\
.13 \\
.03 \\
.023\end{array}$ & $\begin{array}{c}64.40 \\
15.80 \\
3.24 \\
.52 \\
1.16 \\
2.20 \\
5.50 \\
3.96 \\
1.69 \\
.171 \\
.75 \\
.265 \\
.093 \\
.035\end{array}$ & $\begin{array}{c}72.59 \\
14.45 \\
1.41 \\
.16 \\
.18 \\
.70 \\
4.08 \\
5.10 \\
.71 \\
.142 \\
.30 \\
.047 \\
.08 \\
.007\end{array}$ & $\begin{array}{r}66.97 \\
14.80 \\
2.73 \\
.33 \\
.68 \\
1.48 \\
3.49 \\
6.49 \\
.73 \\
.147 \\
.50 \\
.132 \\
.076 \\
.021\end{array}$ & $\begin{array}{l}59.66 \\
16.38 \\
3.65 \\
2.92 \\
3.61 \\
5.15 \\
3.93 \\
2.62 \\
0.70 \\
.365 \\
.96 \\
.255 \\
.086 \\
.052\end{array}$ \\
\hline TOTAL & 99.83 & 98.49 & 99.06 & 99.57 & 100.00 & 99.78 & 99.96 & 98.58 & 100.34 \\
\hline
\end{tabular}

1) W76-79, Cretaceous or early Tertiary basalt, aphanitic member (andesite of Shakespeare); Pyramid subdistrict of Lordsburg mining district, about $150 \mathrm{~m}$ (480 $\mathrm{ft}$ ) southwest of Susie mine, NW1/4 SW1/4 sec. 1, T. 24 S., A. 19 W.

2) W76-24, Cretaceous or early Tertiary basalt, porphyritic member (andesite of Gore Canyon); Gore Canyon, west of Pyramid Peak, NW1/4 NW1/4 sec. 7, T. 24 S., R. 18 W.

3) W76-36, andesite of Holtkamp Canyon; unnamed side canyon from Holtkamp Canyon about $1.2 \mathrm{~km}(0.7 \mathrm{ml})$ west-northwest from Rainbow well, NE1/4 SW1/4 NW $1 / 4$ sec. 29, T. 25 S., R. 18 W.

4) W76-35, tuff of Woodhaul Canyon; peak on eastern shoulder of south Pyramid Peak, SW1/4 NW1/4 SW1/4 sec. 28, T. 25 S., R. 18 W.

5) W76-89, tuff of Woodhaul Canyon, biotite-rich zone in upper part of unit; drainage, approximately $300 \mathrm{~m}(1,000 \mathrm{ft})$ northeast of Rattler well, NE1/4 SW1/4 sec. 23 , T. 25 S., R. 18 W.

6) W76-31, tuff of Graham Well; knob of 4,820 ft elevation, approximately $300 \mathrm{~m}(1,000 \mathrm{ft})$ west-southwest of windmill at Mexican Joe's Camp, Jose Placencia Can yon, NE1/4 NW1/4 sec. 6, T. 25 S., R. 18 W.

7) W76-27, rhyolite of Pyramid Peak; water tank of KIpp (Muir) Ranch, on south boundary of Lordsburg quadrangle, SW/4 NE $1 / 4$ sec. 3, T. 24 S., R. 18 W.

8) W76-28, Aimrock Mountain group, tuff 2, approximately $8 \mathrm{~m}$ (26 ft) above base; hill, 4,800 ft elevation, approximately $300 \mathrm{~m}$ ( $1,000 \mathrm{ft}$ ) south-southeast of North Linn tank, just west of center, sec. 28, T. 24 S., R. 18 W.

9) W76-30, Aimrock Mountain group, basaltic andesite 1; NE1/4 NE1/4 SW1/4 sec. 28, T. 24 S., R. 18 W. High SiOz content may reflect small amount of secondary opal.'

end of the Pyramid Mountains. It consists of altered tuff beds and porphyritic flows, usually brown, gray, or purple, with phenocrysts of plagioclase and small crystals of augite. The base is covered; however, about 300 $m(1,000 \mathrm{ft})$ of andesite is exposed. The name is derived from exposures in Holtkamp Canyon, in secs. 20 and 30 , T. 25 S., R. 18 W. Similar andesite occurs at the base of the mid-Teritary volcanic section throughout most of southwest New Mexico and is usually about 38-39 m.y. old (Elston and others, 1976). A date of $33.1 \pm 0.7$ m.y., determined for the andesite of Holtkamp Canyon, is younger than the date of some stratigraphically higher rocks. This 33.1-m.y. date may be the age of heating and alteration associated with the Muir cauldron rather than the primary age of the andesite.

No contact has yet been found between the andesite of Holtkamp Canyon and the Cretaceous or early Tertiary basalt. The units seem to differ chemically. The aphanitic and porphyritic members of the Cretaceous or early Tertiary basalt both contain approximately $51 \%$ $\mathrm{SiO}_{2}$ and $7.5 \% \mathrm{H}_{2} \mathrm{O}^{+}$(table 1 , columns 1 and 2); the andesite of Holtkamp Canyon contains approximately $59 \% \mathrm{SiO}_{2}$ and $4 \% \mathrm{H}_{2} \mathrm{O}^{+}$(table 1 , column 3 ). On the geologic map (back pocket), a divide between the two units was arbitrarily placed at the Mansfield-Rockhouse fault zone; andesite south of this zone was mapped as andesite of Holtkamp Canyon.

\section{Rocks of Muir cauldron- Pyramid Mountains volcanic complex}

All rocks associated with the Muir cauldron have been placed in the Pyramid Mountains volcanic complex. Their phenocrysts are characterized by the presence of plagioclase and ferromagnesian minerals (mainly biotite) and the scarcity or absence of quartz and sanidine. The complex formed in two stages, separated by an interval of caldera collapse and alteration. First-stage eruptions of the Muir cauldron began with rhyolite lavas and small amounts of tuff, the rhyolite of Jose Placencia Canyon. The eruptions culminated with the eruption of a rhyolite ash-flow tuff, the tuff of Woodhaul Canyon (fig. 3). Both units are pervasively altered. Caldera collapse, during eruption of the rhyolite of Woodhaul Canyon, was accompanied by widespread slumping of the caldera walls and formation of megabreccia, followed by a period of hydrothermal alteration, which in turn was followed by renewed eruptions. This second stage of eruptions began with eruption of an ash-flow tuff, the tuff of Graham Well. The rather limited outcrop area of the tuff of Graham Well is surrounded by two belts of felsic flows, domes, associated tuffs, and andesite flows. The earlier and inner belt consists of rhyolite of Pyramid Peak and associated tuffs. Latite of Uhl Well and the rhyolite of Pyramid Peak are interpreted as successive outer bands of ringfracture domes of the Muir cauldron; the associated tuffs, flows, and lake beds are interpreted as moat and flank deposits (fig. 4).

Rhyolite of Jose Placencia Canyon-The thyolite of Jose Placencia Canyon consists mainly of precollapse domes and flows of crystal-poor flow-banded rhyolite. Phenocrysts are mainly oligoclase-andesine, sparse biotite, sporadic quartz, and rare sanidine; total phenocryst content is usually less than $5 \%$. The flows and domes form a broad northwest-trending outcrop band from sec. 16, T. 25 S., R. 18 W. to sec. 15, T. 24 S., R. $19 \mathrm{~W}$. The outcrop band is interpreted as a segment of the incipient ring-fracture zone of the Muir cauldron, preserved in a northwest-trending graben. 


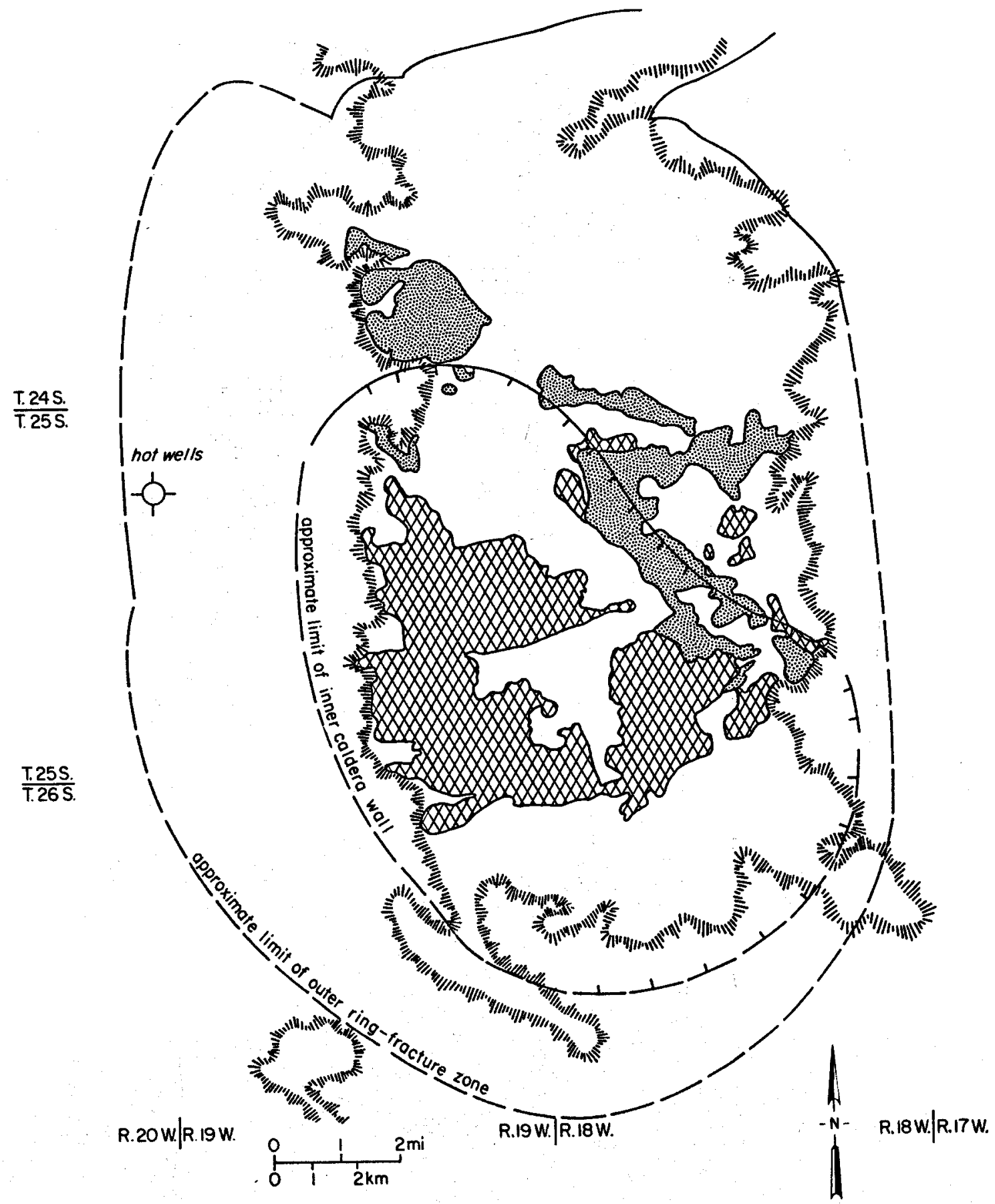

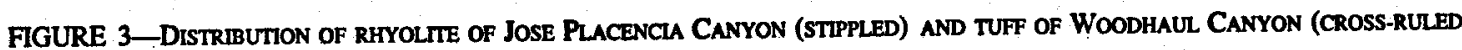
PATTERN).

The type locality is in Jose Placencia Canyon in SE $1 / 4$ sec. 21, T. 24 S., R. 18 W.

At the southeast end of the outcrop belt, in and around sec. 22, T. 25 S., R. 18 W., rhyolite of Jose Placencia Canyon intrudes rhyodacite flows that contain $5-7 \%$ biotite but are otherwise similar to the rhyolite intrusions. The biotite-rich flows have been mapped as the rhyodacite member of the rhyolite of Jose Placencia Canyon. In sec. 10, T. 25 S., R. 18 W., and secs. 2 and 11, T. 24 S., R. 19 W., a poorly to densely welded ash-flow tuff lies beneath the rhyolite of Jose Placencia Canyon and has been mapped as a tuff member. This ash-flow tuff differs from the tuff of Woodhaul Canyon only in stratigraphic position. Dikes and possible flows of crystal-rich (24-45\% oligoclase and sparse biotite) porphyritic rhyolite have been mapped as a separate member in secs. 11 and 13, T. 24 S., R. 19 W., west of the Leitendorf Hills. This member has only scattered outcrops of uncertain stratigraphic position but seems to be a source of abundant clasts in the tuff members of a later unit, the rhyolite of Pyramid Peak.

TUFF OF WOODHAUL CANYON-The tuff of Woodhaul Canyon is the main fill of the Muir cauldron. This 


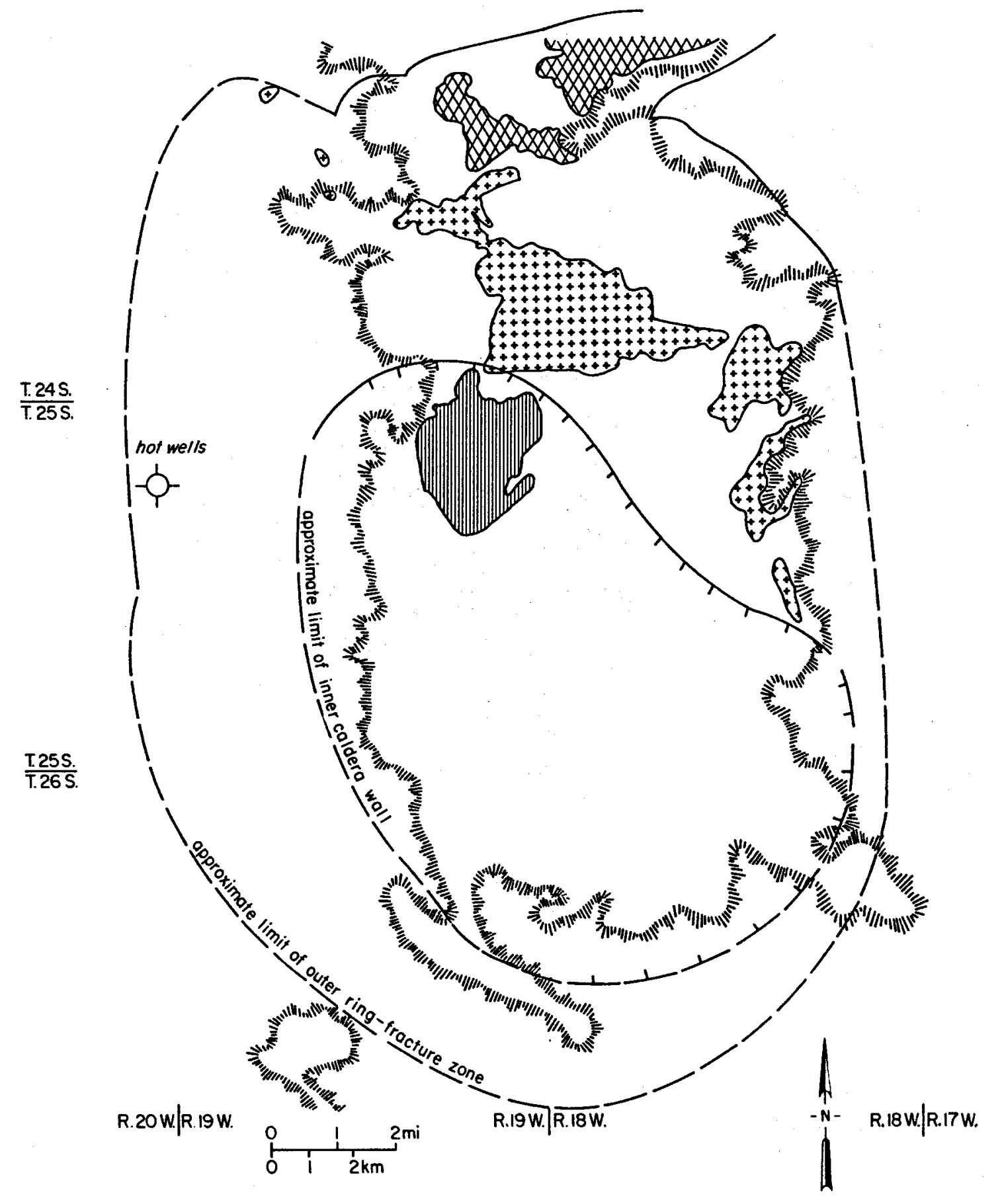

FIGURE 4-DISTRIBUTON OF TUFF OF GRAHAM WELL (CLOSELY RULED LINES), LATTTE OF UHL WELL (CROSSES), AND FLOW MEMBER OF RHYOLITE OF PYRAMID PEAK (CROSS hatChED).

tuff is a nonwelded to densely welded, crystal-poor, ashflow tuff, generally light gray to dark brown, locally with black vitrophyre at the base. Phenocrysts of oligoclase-andesine, sparse biotite, and minor sanidine make up 5-10\% of the rock. The content of pumice lapilli is variable, but inclusions of andesite and rhyolite, to $1 \mathrm{~cm}$, are abundant. Several cooling units are present and appear to be crudely zoned. They seem to become enriched in crystals and more mafic toward the top, especially if the tuff of Graham Well is included as an upper member (table 1, columns 4, 5, and 6). The welded parts of the tuff tend to be closely jointed.
The maximum exposed thickness of the tuff of Woodhaul Canyon, approximately $425 \mathrm{~m}(1,400 \mathrm{ft})$, is around South Pyramid Peak. The top of the unit has been eroded off. The tuff is named for Woodhaul Canyon, located on the south side of Lightning Dock Mountain (sec. 23, T. 25 S., R. 19 W.). A K-Ar age of about $36.8 \pm 0.8 \mathrm{~m}$.y. was reported by $P$. E. Damon and $M$. Shafiqullah (Deal and others, 1978).

North of Rainbow Wash, the tuff of Woodhaul Canyon tends to be altered and full of lithic inclusions, some of them many meters wide. Blocks of andesite of Holtkamp Canyon are abundant in the Russell Hills (secs. 18 
3 and 19, T. 25 S., R. 18 W. and sec. 24, T. 25 S., R. 19 W.) and on the south side of Lightning Dock Mountain (N1/2 sec. 23, T. 25 S., R. 19 W.). Fluidal textures, resembling flow bands, appear near the base of the unit in secs. 18 and 19, T. $25 \mathrm{~S}$., R. $18 \mathrm{~W}$. These textures seem to have formed as a result of compaction and of flow from steep slopes. The slopes are interpreted as part of the caldera wall, formed by andesite of Holtkamp Canyon. Blocks of andesite many meters long were engulfed by the tuff of Woodhaul Canyon, forming a caldera-collapse megabreccia in the sense of Lipman (1976). In a number of places, the megabreccia member of the tuff of Woodhaul Canyon was mapped separately.

At the head of Jose Placencia Canyon (secs. 4, 5, and 6, T. 24 S., R. 18 W.) the megabreccia member contains blocks of Paleozoic limestone (mainly from the Horquilla formation [Pennsylvanian]; Needham, 1937, identified Triticites sp.) up to $50 \mathrm{~m}(160 \mathrm{ft})$ long and smaller boulders (to $1 \mathrm{~m} ; 3 \mathrm{ft}$ ) of andesite of Holtkamp Canyon and Precambrian granite. At the foot of the southern end of Lightning Dock Mountain, the megabreccia member includes blocks of conglomerate (clasts of andesite, Precambrian granite, and Paleozoic limestone), freshwater limestone, andesite breccia, and andesite flow rock. Higher on the west and south faces of Lightning Dock Mountain, blocks of andesite of Holtkamp Canyon, up to $30 \mathrm{~m}$ (100 ft) long, occur in megabreccia lenses several kilometers long.

Crystal-poor rhyolite flows and dikes, younger than the main ash-flow tuff, were mapped as a separate member on the top of Lightning Dock Mountain and in Woodhaul Canyon.

TUFF OF GRAHAM WELL-The tuff of Graham Well is a quartz-latite ash-flow tuff. The $\mathrm{SiO}_{2}$ content is low for an ash-flow tuff $(64.4 \%)$, possibly because inclusions of andesite and basalt could not be entirely removed before chemical analysis. It can be distinguished from the tuff of Woodhaul Canyon by the greater abundance of phenocrysts of oligoclase-andesite and biotite and by the presence of hornblende. Sanidine and quartz are present in some samples. The groundmass is heavily stained with hematite. The type locality is directly northwest of Graham Well, in NW $1 / 4$ and SW $1 / 4$ sec. 7, T. 25 S., R. $18 \mathrm{~W}$. At this location the base of the unit has abundant inclusions of andesite of Holtkamp Canyon, up to $50 \mathrm{~cm}$ (20 inches) in diameter.

The tuff of Graham Well could be considered a relatively mafic upper member of the tuff of Woodhaul Canyon. The relationship between the two units is complicated. The initial collapse of the Muir cauldron and at least some hydrothermal alteration occurred during or after eruption of the tuff of Woodhaul Canyon and prior to eruption of the tuff of Graham Well, but the duration of these events need not have been great. The irregular wall of the caldera that confined almost all of the tuff of Woodhaul Canyon seems to have been enlarged by massive slumping during eruption of the tuff of Graham Well. For example, around Goat Mountain and Mexican Hat, in secs. 11, 12, and 13, T. 25 S., R. 19 W., the tuff of Graham Well crops out as arcuate slices approximately $3 \mathrm{~km}(2 \mathrm{mi})$ long with intervening slices of andesite that seem to be megabreccia blocks of andesite of Holtkamp Canyon. As andesite slices slid in- to the caldera, their upper surfaces disintegrated and the resulting fragments were intermingled with a matrix of tuff of Graham Well. The entire mass is best interpreted as the eroded stumps of toreva blocks formed by a second stage of collapse of the Muir caldera. Because of slumping and a highly irregular lower contact with in situ andesite of Holtkamp Canyon, the thickness of the tuff of Graham Well is difficult to measure. Only an erosional remnant, less than $100 \mathrm{~m}(300 \mathrm{ft})$ thick, now remains. Possibly, some tuff of Graham Well was mapped as tuff of Woodhaul Canyon; the units would be difficult to distinguish in places where they are conformable and unaltered.

ANDESITE OF MANSFIELD SEEP-Andesite of Mansfield Seep is a local unit that crops out west of Rimrock Mountain and west of the Leitendorf Hills. Its maximum thickness is approximately $30 \mathrm{~m}(100 \mathrm{ft})$. The type locality is in NW $1 / 4$ sec. 18, T. 24 S., R. 18 W. The unit consists of dark gray or brown lava flows, with rodlike hornblende and augite phenocrysts up to $5 \mathrm{~mm}(0.2$ inches) long and about $10 \%$ plagioclase phenocrysts up to $1 \mathrm{~mm}$ (0.04 inches) long. In a few specimens, sparse flakes of biotite are the only phenocrysts.

LATITE OF UHL WELL-The latite of Uhl Well consists of dark red-brown lava flows and dikes. Andesine phenocrysts make up 15 to $20 \%$ of the rock. The earliest flows contain augite and hornblende phenocrysts in a microcrystalline matrix; the later flows have brassy biotite flakes in a cryptocrystalline matrix. Maximum total thickness is over $200 \mathrm{~m}$ (650 ft). The type locality is in W $1 / 2$ sec. $11, T .25$ S., R. 18 W., and the $\mathrm{K}$-Ar age is $36.6 \pm 0.8 \mathrm{~m} . \mathrm{y}$.

The latite of Uhl Well crops out in a broad, slightly arcuate northwest-trending outcrop belt diagonally across the Pyramid Mountains from SW $1 / 4$ sec. 24, T. 25 S., R. 18 W. to sec. 14, T. 25 S., R. 19 W. It is concentric with, and outside, the main belt of rhyolite of Jose Placencia Canyon. The latite of Uhl Well is interpreted as domes and flows that erupted from a ringfracture zone of the Muir cauldron after its final collapse. North-trending dikes of latite of Uhl Well crop out in a belt about $3.5 \mathrm{~km}(2 \mathrm{mi})$ wide, from Jose Placencia Canyon northward to Mansfield Wash.

RHYOLITE OF PYRAMID PEAK - The rhyolite of Pyramid Peak consists of a lower tuff member, a flow member, and an upper tuff member. The lower tuff member consists of up to $80 \mathrm{~m}(260 \mathrm{ft})$ of sandstone and conglomerate with clasts of all earlier units, pumice flows, and minor ash flows. Directly south and west of Dogs Head, in S $1 / 2$ sec. 4, T. 24 S., R. 18 W., up to $30 \mathrm{~m}(100$ $\mathrm{ft})$ of thinly laminated lake beds occur below $50 \mathrm{~m}$ (160 $\mathrm{ft}$ ) of bedded pumiceous tuff and were mapped separately. The lake beds include layers of chert and freshwater limestone. Sandstone, rhyolite breccia, and ashflow tuff younger than the flow member crop out on the northeast flank of the Leitendorf Hills and in the Lordsburg quadrangle, north of Pyramid Peak.

The flow member, up to $300 \mathrm{~m}$ thick, consists of sparsely porphyritic rhyolite with $2 \%$ phenocrysts of oligocene-andesine and black biotite. In the Leitendorf Hills much of the rock is glassy and has been prospected for perlite.

The entire unit is named for Pyramid Peak, in NW1/4 sec. 8, T. 24 S., R. 18 W. The rhyolite of Pyramid Peak 
crops out north of the belt of latite of Uhl Well. The pyroclastic and sedimentary beds of the tuff members are interpreted as moat and flank deposits of the Muir cauldron; the flow member is interpreted as deposits erupted in the outer ring-fracture zone.

\section{Post-cauldron rocks}

RIMROCK MOUNTAIN GROUP-Rocks of the Rimrock Mountain group consist of eight rhyolite or quartz-latite ash-flow-tuff units interlayered with three basaltic andesite flow units and with sandstone and conglomer- ate beds. The maximum cumulative thickness is approx- imately $1,000 \mathrm{~m}(3,300 \mathrm{ft})$ but individual units thicken and thin in different places, so that the actual thickness in any one place is always much less. At Rimrock Mountain, the type locality (sec. 19, T. 24 S., R. 18 W.), the thickness is approximately $300 \mathrm{~m}(1,000 \mathrm{ft})$.

The Rimrock Mountain group occurs in four isolated areas (fig. 5): 1) Northern part of the mapped area, in a northeast-dipping block that runs southeast from Rimrock Mountain. The unit lies unconformably on latite of Uhl Well in most of this block. The north side of the block is separated from rhyolite of Pyramid Peak by the

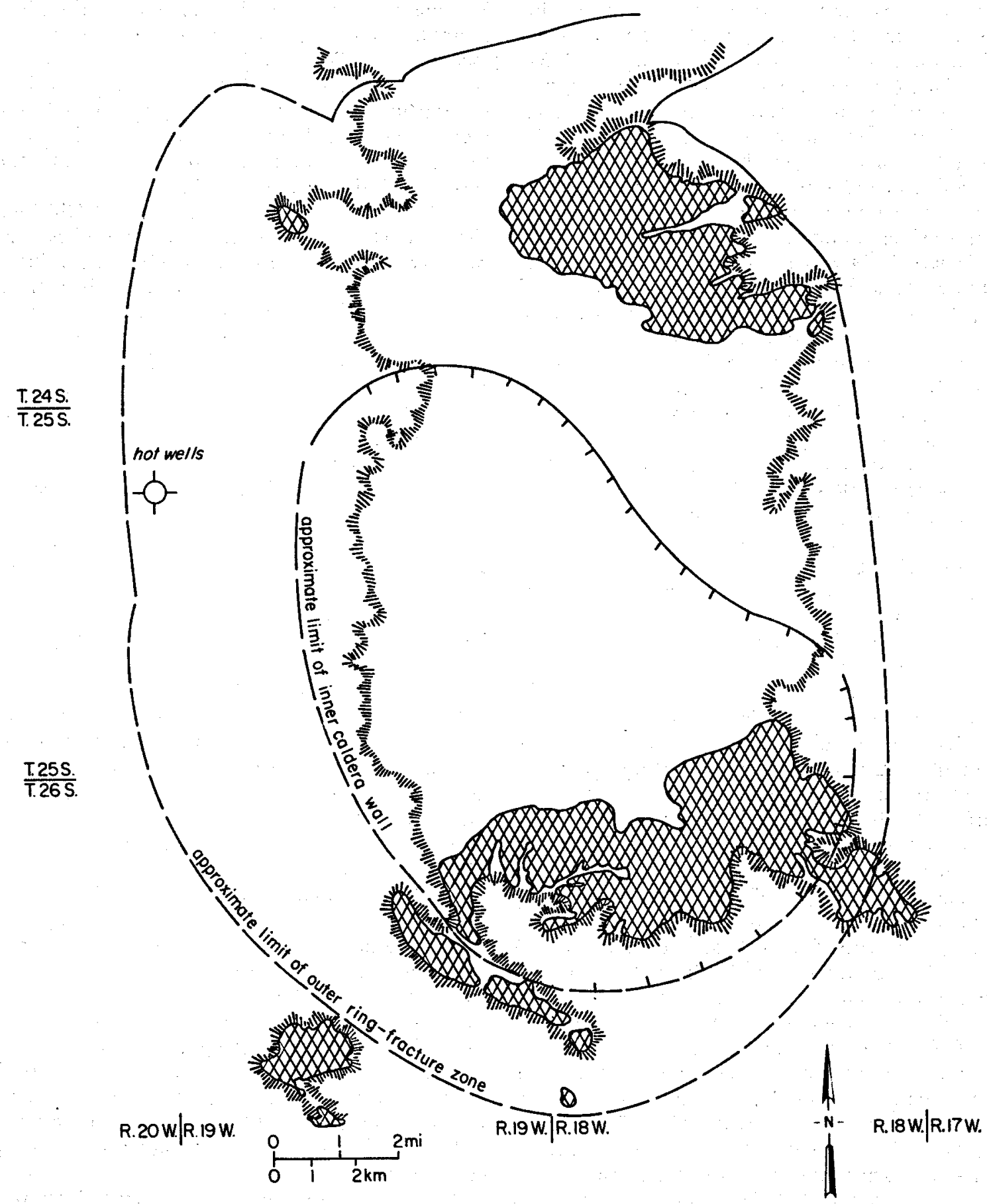

FIGURE 5-DISTRIBUTION OF RIMROCK MOUNTAIN GROUP (CROSS-RUIED PATTERN). 
Rockhouse-Mansfield fault zone. 2) Southern end of the Pyramid Mountains. The Rimrock Mountain group in this area has been broken by faults into a mosaic of blocks. The blocks dip in different directions, except on the southwestern edge of the Pyramid Mountains. There, the rocks dip uniformly to the southwest, opposite in direction to the northern belt. The southern belt is separated from andesite of Holtkamp Canyon and tuff of Woodhaul Canyon by the Pinkey Wright-Elephant Back fault zone; the base of the Rimrock Mountain group is not exposed. 3) Threemile Hills (on the Old Animas Road, 3 mi north of Animas), an isolated group of hills southwest of the main range of the Pyramid Mountains. Here, a thin basal andesite (possibly correlative with the andesite of Holtkamp Canyon) rests on Cretaceous sandstone (Mojado? Formation) and is overlain by ash-flow-tuff beds and interlayed andesite and sandstone of the Rimrock Mountain group. Details of correlation with the Rimrock Mountain group elsewhere in the Pyramid Mountains are uncertain. The Pyramid Mountains volcanic complex is absent. 4) Around Twelvemile Hill (SE $1 / 4$ sec. 16, T. 24 S., R. 19 W.), one of a low group of small hills off the west flank of the Pyramid Mountains. The rocks dip steeply; no top or bottom is exposed.

The same units of the Rimrock Mountain group can be recognized in all outcrop areas except, possibly, the Threemile Hills. The Rimrock Mountain group probably once covered most or all of the Pyramid Mountains; the Muir cauldron seems to have had low relief at the time the rocks of the Rimrock Mountain group were erupted. Perhaps a period of beveling occurred between the end of activity of the Muir cauldron and its burial by the Rimrock Mountain group. Alternatively, burial could have occurred after cauldron collapse but prior to resurgence. By either interpretation, the downfaulted blocks in which rocks of the Rimrock Mountain group have been preserved on the southern end of the map areas are interpreted as segments of the cauldron moat. The northern block is preserved between the inner and outer ring-fracture zones of the cauldron. The Threemile Hills appear to be outside the outer ring-fracture zone of the cauldron. Rocks related to the cauldron are absent in the Threemile Hills; rocks of the Rimrock Mountain group were deposited on precauldron andesite and sedimentary rocks.

In general, felsic tuffs of the Rimrock Mountain group contain sanidine and quartz phenocrysts (only tuff 2 does not); in contrast to tuffs of the Pyramid Mountains volcanic complex, which have plagioclase phenocrysts but little or no sanidine or quartz.

The following units have been mapped within the Rimrock Mountain group:

TUFF 1-Ash-flow tuff; phenocrysts of sparse (approximately 5\%) sanidine, minor quartz, trace plagioclase and biotite; abundant pumice. Welding poor to

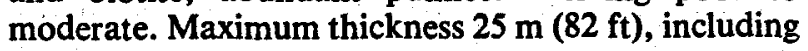
$14 \mathrm{~m}(46 \mathrm{ft})$ of basal sediments.

TUFF 2-Several ash-flow-tuff cooling units; phenocrysts are moderately abundant (approximately $25 \%$ ), mainly plagioclase, $3-5 \%$ biotite, minor hornblende, trace (xenocrysts?) sanidine, clinopyroxene. Xenoliths of rhyolite and andesite. Welding variable but generally strong, locally to vitrophyre. Hand samples are gray to red brown with reddish pumice streaks. Thickness 30-120 m (100-390 ft). A K-Ar age of about 35.9 m.y. \pm 0.8 m.y. was reported by P.E. Damon and M. Shafiqullah (Deal and others, 1978).

BASALTIC ANDESITE 1-Dark, aphanitic, scoriaceous to dense, microporphyritic, with calcic andesine and magnetite groundmass, approximately $10 \%$ augite microphenocrysts; altered olivine is present in one flow. Abundant secondary opal and chalcedony. Maximum thickness, over $150 \mathrm{~m}$ (490 ft), near probable vent in secs. 21,22 , and 27, T. 24 S., R. 18 W. In Threemile Hills, porphyritic andesine-pyroxenebiotite andesite above a sandstone zone occupies approximately the same stratigraphic horizon.

TUFF 3-Ash-flow tuff, phenocrysts generally less than $1 \mathrm{~mm}$ (0.04 inches), amount variable ( $15 \%$ at base, $5 \%$ at top), quartz, sanidine, calcic oligoclase, minor biotite, trace hornblende; oligoclase/sanidine ratio increases upward. Pumiceous light gray, welding (locally to vitrophyre), and thickness (to $150 \mathrm{~m} ; 490$ $\mathrm{ft}$ ) are greatest in southern Pyramid Mountains. Maximum thickness includes $10-15 \mathrm{~m} \mathrm{(33-49} \mathrm{ft}$ ) basal sediments. Poorly welded on Rimrock Mountain.

TUFF 4-Ash-flow tuff, phenocrysts moderately abundant $(25-30 \%)$, about half plagioclase, the rest quartz, sanidine, minor brassy biotite, trace hornblende or clinopyroxene, seriate to $5 \mathrm{~mm}$ ( 0.2 inches). Dark brown, highly welded; abundant pumice fragments usually $1 \mathrm{~cm}$ (0.4 inches) long, locally to $50 \mathrm{~cm}$ (20 inches). Rock forms prominent ledge, up to $60 \mathrm{~m}$ (200 ft) thick, on Rimrock Mountain, 15-25 m (49$82 \mathrm{ft}$ ) in southern end of range.

TUFF 5-Ash-flow tuff, phenocrysts of sparse (2-5\%) sanidine, variable plagioclase, rare quart $z$ and biotite; basaltic andesite xenoliths. Groundmass is chalky and pink in hand specimen; glass shards can be resolved

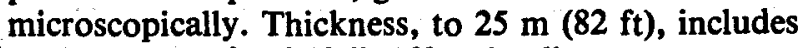

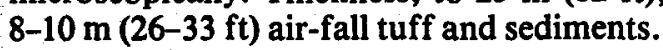

TUFF 6-Ash-flow tuff, prominent marker, phenocrysts of abundant (40-50\%) oligoclase, sanidine, quartz, biotite, up to $1 \%$ hornblende, trace sphene. The unit consists of several highly welded cooling units, locally interlayered with thin air-fall tuff beds and overlain by sediments. Thickness is $45-75+m$ (148-246 ft). May correlate with uppermost part of Gillespie Tuff of Animas Mountains (Zeller and Alper, 1965). K-Ar sanidine age of $34.2 \pm 0.6$ m.y. was reported by P. E. Damon (Deal and others, 1978).

BASALTIC ANDESITE 2-Aphanitic, dark gray to black, platy fractures on outcrops, trachytic matrix of plagioclase, magnetite, augite. Patchy distribution, thickness to $30 \mathrm{~m}$ (100 ft).

CONGLOMERATE AND SANDSTONE-Mainly boulder conglomerate, boulders (of all units through tuff 6)

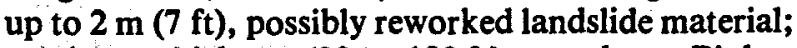
maximum thickness $(30 \mathrm{~m} ; 100 \mathrm{ft}$ ) on and near Pinkey Wright Mountain (S1/4 sec. 6, T. 26 S., R. 18 W.).

TUFF 7-Ash-flow tuff, phenocrysts sparse to moderately abundant (10-15\%, more crystal rich at base), chatoyant sanidine (moonstone), quartz, sparse copper-colored biotite, trace augite and hornblende. Matrix consists of shards and gray-brown pumice lapilli. Vitrophyre occurs locally at the base of the tuff. Maximum thickness, $250 \mathrm{~m}(820 \mathrm{ft}$ ) in SE $1 / 4 \mathrm{sec}$. 


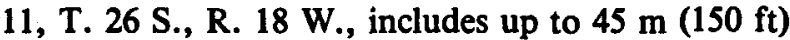
pumiceous sandstone at the base and 30-45 $\mathrm{m}$ (98-150 $\mathrm{ft}$ ) at the top.

BASALTIC ANDESITE 3-Porphyritic basaltic andesite or andesite, dense, dark brown, about $25 \%$ phenocrysts of andesine and augite, commonly glomeroporphyritic; occurs as small erosional remnants of lava flows and as a small plug(?) just south of China Pond (sec. 24, T. 26 S., R. 19 W.). Locally, the same stratigraphic interval may be occupied by sandstone with basaltic andesite boulders.

TUFF 8-Ash-flow tuff, phenocrysts moderately abundant (25-35\%), sanidine (moonstone), quartz, minor oligoclase, trace biotite. Pumice content is low, the rock is nonwelded to densely welded; its maximum thickness is over $90 \mathrm{~m}(300 \mathrm{ft})$.

Throughout southwestern New Mexico, ash-flow tuffs from a single center tend to show progressive increases in size and number of phenocrysts and progressive changes in mineral content. If this were true here, the Rimrock Mountain group probably came from at least three unrelated centers. Tuffs 1 and 3 may have come from one source, tuffs 2,4 , and 6 from another, and "moonstone" tuffs 5, 7, and 8 from a third.

\section{Rocks of Animas Valley}

Pre-Tertiary AND Tertiary Rocks-Within the Animas Valley, northwest of the Threemile Hills, a group of low hills is made up of fusulinid-bearing Pennsylvanian(?) limestone and of Tertiary rhyolite that cannot be correlated with any unit of the Pyramid Mountains. The presence of quartz and sanidine in the rhyolites suggests affinity with the Rimrock Mountain group. The absence of rocks of the Pyramid Mountains volcanic complex and the presence of Paleozoic rocks suggest that these hills are outside the Muir cauldron. Farther north, the rocks of Table Top Mountain and the rocks encountered by drilling into the geothermal anomaly at the McCants home are tentatively interpreted as consolidated early Miocene(?) valley fill.

Each hill in the Animas Valley has distinct rock types. In sec. 25, T. $26 \mathrm{~S}$., $R .19 \mathrm{~W}$. is a hill consisting of a succession of rhyolite ash-flow-tuff cooling units and a zone of bedded pumiceous tuff. Welding of the ash-flow tuffs varies from poor to intense; vitrophyre occurs above the bedded tuff zone. Phenocrysts (approximately 15\%) consist of quartz, sanidine (moonstone), and plagioclase. Sparse biotite occurs only in the lowest exposed cooling unit; higher units contain sphene, clinopyroxene, and/or hornblende. Compressed pumice lenses are conspicuous. The general aspect is that of higher members of the Rimrock Mountain group (tuffs 7 and 8), but no exact correlation is possible and the unit has not yet been identified in the Peloncillo Mountains. A hill in secs. 12 and 13, T. 26 S., R. $18 \mathrm{~W}$. is a dome of flow-banded rhyolite. Sparse (approximately 2\%) phenocrysts are of plagioclase, quartz, and sanidine.

Table Top Mountain, in SW1/4 sec. 6, T. 26 S., R. 19 W., consists of two clastic units. At the base, approximately $25 \mathrm{~m}(82 \mathrm{ft})$ of polymictic poorly bedded mudflows(?) are exposed, with boulders to $15 \mathrm{~cm}$ (6 inches) of basalt, andesite, and a variety of rhyolites in a sandy matrix. The resistant cap consists of approximately 50 $m(160 \mathrm{ft})$ of well-cemented and well-bedded breccia, with angular and slabby clasts which are generally less than $3 \mathrm{~cm}$ (1 inch) wide and are rarely up to $25 \mathrm{~cm}(10$ inches). The most abundant clasts are of crystal-poor rhyolite with phenocrysts of biotite. Biotite altered to magnetite and feldspar altered to clay minerals are the only identifiable phenocrysts. Quartz and potassium feldspar occur in the matrix of the breccia but not as primary phenocrysts in the clasts. Because of the absence of quartz and sanidine phenocrysts, these clasts are tentatively classified with the Pyramid Mountains volcanic complex. A small fraction of the clasts consists of quartz-bearing ash-flow tuff, flow-banded rhyolite, and andesite. The beds are regular and $2-25 \mathrm{~cm}$ (1-10 inches) thick. The rock could have formed from sheet wash during a long succession of torrential storms; each layer would correspond to one downpour. The rocks are strongly cemented and were tilted and uplifted above the valley floor, which suggests that they are older than the main stage of basin-and-range faulting. They could be old valley fill, corresponding to the early Miocene basal part of the Gila Conglomerate. Alternatively, they could be late-stage moat fill of the Muir cauldron. The other two rhyolite hills in the vicinity of Table Top Mountain lie outside the ring-fracture zone.

The cuttings from the McCants wells appear to be lithic tuff. The lithic clasts are of gray rhyolite with phenocrysts of sericitized plagioclase and a ferromagnesian mineral (biotite?) altered to opaque iron oxides and a groundmass of altered glass and plagioclase. Neither quartz nor sanidine occur as phenocrysts. Sanidine is present in the altered groundmass, quartz in fine mosaics in the groundmass and in lenses that may have formed from recrystallized pumice or from the fillings of vapor-phase cavities. By general aspect (phenocrysts of plagioclase but not of quartz or sanidine), the clasts belong to the older rhyolites of the region, such as the Pyramid Mountains volcanic complex.

The well-cemented matrix to these clasts is stained brown and consists of clay (probably altered glass without identifiable shards) and abundant, angular, $0.5-\mathrm{mm}$ (0.02-inch) fragments of quartz, sanidine, altered plagioclase, and biotite. Elongated crystal fragments and wispy altered pumice(?) fragments are crudely aligned; otherwise no evidence of fluidal texture or sedimentary laminae exists. Neither the matrix nor the clasts of these cuttings can be assigned to any known stratigraphic unit in the Pyramid Mountains. The entire rock could be consolidated early Miocene(?) valley fill, similar to the cap of Table Top Mountain. In both the well cuttings and in the cap of Table Top Mountain, quartz and sanidine are abundant in the matrix but not in the clasts.

EARLY FANGLOMERATE-Coarse fanglomerate is locally exposed in the valley that divides the Pyramid Mountains from the Animas Mountains to the south. This fanglomerate consists of boulders up to $50 \mathrm{~cm} \mathrm{(20}$ inches) of moonstone-bearing rhyolite ash-flow tuff, basaltic andesite, and crystal-poor, sanidine-bearing, flow-banded rhyolite. The matrix is tuffaceous sand and gravel. The thickness and age of the deposit are unknown. 
QUATERNARY DEPOSITS, BY STEPHEN G. WELLS, UNIVERSITY OF NEW MEXICO-Quaternary surficial materials of the Animas Valley have been divided into piedmont and valley-floor deposits. Piedmont deposits consist of coalescing Holocene and Pleistocene alluvial fans and pediment deposits. In addition, modern or active wash sediment, which originated within the interior of the Pyramid Mountains and was deposited on the piedmont surface, is included. Since the rhyolite chips recovered from the McCants hot wells are apparently derived from consolidated rock rather than from loose boulders, the piedmont deposits near the wells can be no more than approximately $25 \mathrm{~m}(82 \mathrm{ft})$ thick. In the southwest part of the mapped area, inselbergs rise through the piedmont deposits suggesting that here also the deposit thickness is not great.

Valley-floor deposits are composed of fluviodeltaic deposits associated with the ancient Lake Animas, as well as modern eolian deposits (coppice dunes and sand blankets) and active sheetwash deposits. The valleyfloor deposits are much thicker than the piedmont deposits, but the thickness of the former is unknown. Water wells do not penetrate them and the records of wildcat wells for oil and gas have not been released.

The Quaternary piedmont deposits have been displaced by the Animas Valley fault, probably during the late Pleistocene or early Holocene. Vertical of fset of old fan surfaces that have well-developed soil horizons occurs over a distance of $16 \mathrm{~km}(10 \mathrm{mi})$. The fault scarp is subparallel to the mountain front and is sinuous. Nearly

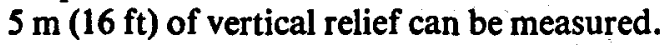

\section{Regional correlation}

The same general succession of volcanic-rock types, from andesite to plagioclase-biotite-quartz latite, sanidine-quartz-plagioclase-biotite rhyolite or quartz latite, and sanidine-quartz-biotite "moonstone" tuff has been found throughout southwest New Mexico, as has the interlayering of basaltic andesite with felsic rocks in the upper part of the section (Elston and others, 1976). This regional similarity does not imply exact stratigraphic correlation, but it does imply generally similar conditions of melting and crystallization of magmas.

The correlation of individual units is less certain. The widespread nature of the Gillespie Tuff was noted long ago by the late R. A. Zeller (Dane and Bachman, 1965). Tuff 6 , tentatively identified as the upper part of Gillespie Tuff, was also found in Coyote Hills, east of the Pyramid Mountains. A sample of Gillespie Tuff from the Animas Mountains yielded a biotite K-Ar age of $32.9 \pm 0.7$ m.y., and a sample of tuff 6 was dated at $34.2 \pm 0.6 \mathrm{~m} . \mathrm{y}$. A fission-track age of $36.1 \pm 3.2 \mathrm{~m} . \mathrm{y}$. was obtained from a sample from the Coyote Hills by C. W. Naeser (Marvin and others, 1978).

\section{Intrusive rocks}

Intrusive rocks consist of a composite stock north of Lightning. Dock Mountain (fig. 6) and numerous dikes, many of them more or less radial to Lightning Dock Mountain. Dikes were mapped with a separate designation only if they could not be identified as intrusive equivalents of a stratigraphic unit. No dikes are known to intrude the Rimrock Mountain group or younger rocks.

The composite stock crops out in secs. 10,11, 14, and 15, T. 25 S., R. 19 W. The stock consists of fine-grained diorite (andesine labradorite, magnetite, biotite, subcalcic? augite, hornblende, and secondary amphibole), monzonite porphyry (plagioclase phenocrysts to $3 \mathrm{~mm}$ ( 0.1 inches) in a matrix of felty feldspars, magnetite, and chloritized ferromagnesian minerals), and a rhyolitic phase that was not mapped separately. Dikes of monzonite porphyry radiate for at least $5 \mathrm{~km}(3 \mathrm{mi})$ from the outcrop area, suggesting that the stock is more extensive below the surface. The tuff of Woodhaul Canyon is the youngest unit intruded by the stock, which may have been emplaced during resurgence of the Muir cauldron. In the absence of radiometric dates, this relative timing of emplacement and resurgence has not been verified.

A hill in N1/2 sec. 11, T. 25 S., R. 19 W. consists of black andesite porphyry with approximately $20 \%$ phenocrysts (to $1.5 \mathrm{~mm} ; 0.06$ inches) of corroded and zoned plagioclase and less abundant augite in a finegrained matrix of plagioclase and magnetite. In some samples, augite is chloritized and subordinate to hornblende and biotite. The intrusion was emplaced in rocks as young as tuff of Graham Well, partly discordantly and partly concordantly. Its $\mathrm{K}$-Ar whole-rock age is $29.4 \pm 0.7 \mathrm{~m}$.y. The relationship of andesite porphyry to the nearby composite stock is unknown.

Other dike rocks include fine-grained white rhyolite younger than the main part of the tuff of Woodhaul Canyon, quartz-latite porphyry, and aphanitic andesite. Andesite dikes intrude rocks as young as the rhyolite of Pyramid Peak.

\section{Geologic structure Pre-Oligocene structures}

Pre-Oligocene structures are not exposed in the southern part of the Pyramid Mountains. Regionally, northwest-trending thrust faults, folds, strike-slip faults, and normal faults, probably of Laramide age, have been mapped in the Peloncillo, Animas, Little Hatchet, and Big Hatchet Mountains, Brockman Hills and in the Apache Hills and Sierra Rica. The northeast and west trends of veins in the Pyramid subdistrict are characteristic of late Laramide (late Paleocene to early Eocene) veins throughout this part of New Mexico.

\section{Oligocene structures}

DEVELOPMENT OF THE MUIR CAULDRON-Mid-Tertiary structures are dominated by the Muir cauldron, which seems to be an elongated structure with its long axis striking northwest, roughly parallel to the regional trend of pre-Tertiary basement structures. The caldera wall and ring-fracture zone have been preserved only on part of its northeast side. At least two scenarios could explain the structure of the cauldron. The steps of the first scenario are as follows:

1) Eruption of minor amounts of ash-flow tuff and of 


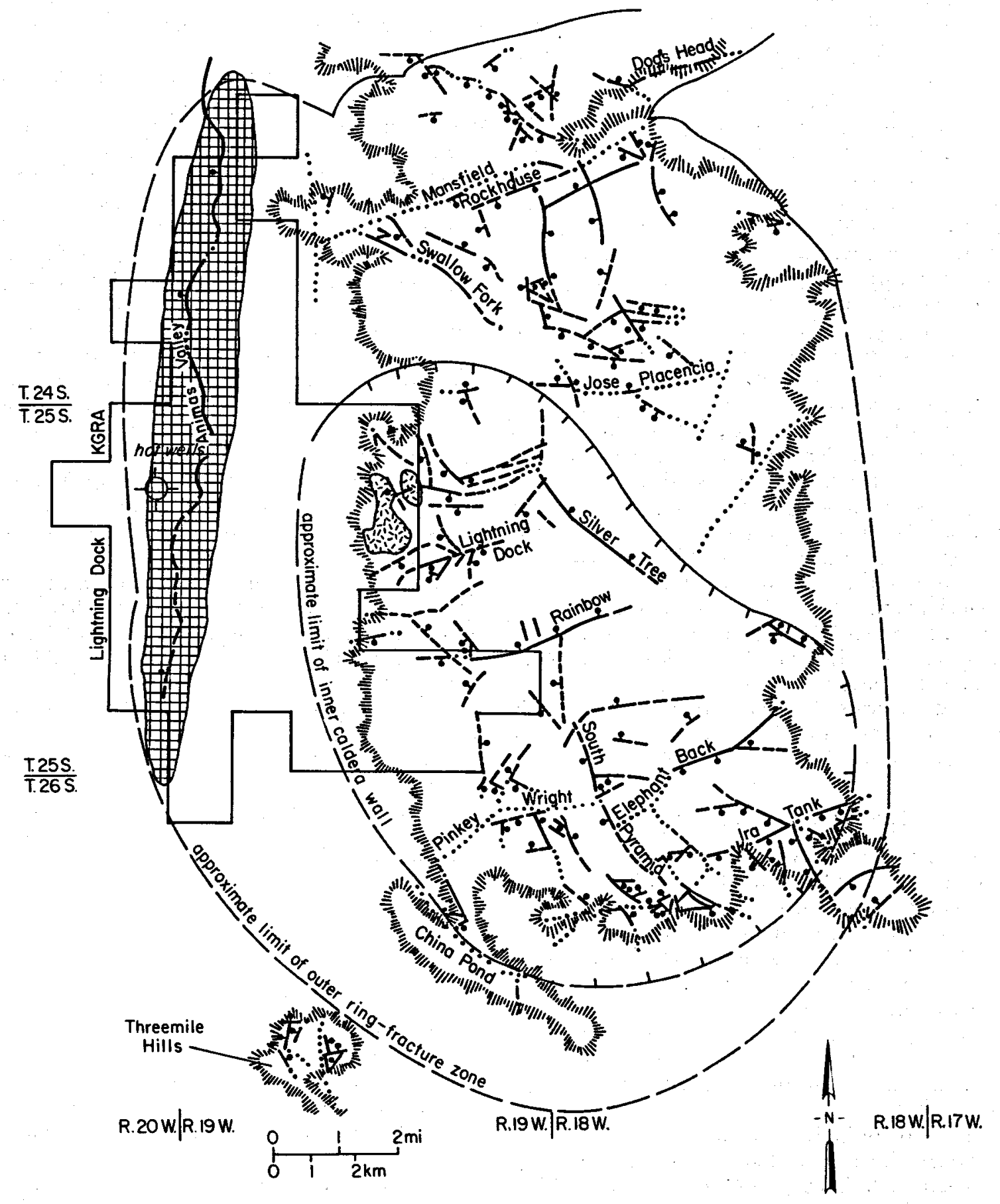

FIGURE 6-Tectonic maP Of southern PYRamid MountaINs. Cross-ruled pattern indicates intersection between Animas Valley fault and ring-fracture zone of Muir cauldron; intersection is considered most favorable for geothermal exploration. Pattern with short lines indicates composite stock.

early ring-fracture domes, the rhyolite of Jose Placencia Canyon (fig. 3).

2) Main-stage ash-flow-tuff eruptions (tuff of Woodhaul Canyon) and caldera collapse. Intense hydrothermal alteration.

3) Late-stage ash-flow-tuff eruptions (tuff of Graham Well) and widening of the caldera by continued collapse (fig. 4).

4) Intrusion of the composite stock, probably as part of a resurgent magma pulse. The timing of this event relative to stages 5-7 is unknown.
5) Eruption of the inner set of ring-fracture domes and flows (latite of Uhl Well).

6) Eruption of outer ring-fracture domes and flows and associated tuff deposits (rhyolite of Pyramid Peak); partial filling of moat by conglomerate and lake deposits.

7) Burial of the Muir cauldron by rocks of the Rimrock Mountain group (fig. 5). The tuff members originated in centers beyond the Pyramid Mountains; at least one basaltic andesite member (member 1) seems to have come from a vent in the ring-fracture zone. 
- 8) Basin-and-range faulting. The Muir cauldron was truncated to the east and west by north-trending normal faults, which border the Animas and Playas Valleys. Internally, faults related to caldera formation were reactivated. The entire cauldron was uplifted into a broad northwest-trending arch (fig. 6). The Rimrock Mountain group was broken by a mosaic of faults and stripped from the center of the cauldron. It is now preserved only in the moat and outside the inner cauldron walls.

By this scenario, the ring-fracture domes of stages 5 and 6 , as well as the intrusions of stage 4, could be interpreted as part of a resurgent magma pulse. By the second scenario, stage 4 is the only resurgent pulse and occurred after stage 7. According to this interpretation, the faults that break the Rimrock Mountain group into a mosaic were formed during resurgent doming, as their pattern suggests. Reactivation during stage 8 would then have played a lesser role. The second scenario requires that the source volcanoes of the Rimrock Mountain group were active before the Muir cauldron became extinct. Burial of the Muir cauldron by rocks of the Rimrock Mountain group occurred subsequent to collapse but prior to resurgence. Accurate radiometric dates may eventually decide between the two scenarios.

Compared with other well-studied cauldrons of southwestern New Mexico (for example, Mount Withington, Emory, or Bursum), the Muir cauldron is small, shallow, and highly complicated. Most of the complications arise from slumping of the cauldron walls and the accumulation of chaotic breccias on the cauldron floor. Possibly, intermittent ash-flow-tuff eruptions of relatively small volume rather than a single catastrophic eruption occurred. The structure of the Muir cauldron will be described in some detail, to document the interpretation that the hot wells of the Lightning Dock KGRA are partly controlled by its ring-fracture zone. The interpretation has a large element of uncertainty, because continuous exposures occur only in the Pyramid Mountains. Structures beneath the Animas and Playas Valleys must be extrapolated from exposures in isolated hills.

GEOMETRY OF THE MUIR CAULDRON-The Muir cauldron conforms to the pattern of cauldrons described by Smith and Bailey (1968), in that it consists of 1) an inner cauldron in which a thick fill of ash-flow tuff accumulated, bordered by a collapsed caldera wall, and 2) three zones of ring-fracture domes, flows, and moat deposits outside the caldera wall (fig. 7), one earlier and two younger than the main cauldron fill.

The inner cauldron has been warped into a broad northwest-trending arch. The outcrop of the composite stock and the chief area of alteration are west of the axis of the arch. The relative roles played in the formation of the arch by resurgent doming and by later basin-andrange faulting has not been determined. The general fault pattern within the inner cauldron (fig. 7) resembles that of the resurgent domes described by Smith and Bailey (1968).

The cauldron has been broken by an en echelon set of northwest-trending longitudinal faults (Swallow Fork, Silver Tree, South Pyramid, and China Pond) and by northeast-trending transverse faults (MansfieldRockhouse, Jose Placencia, Lightning Dock, Rainbow, and Pinkey Wright-Elephant Back; fig. 6). Many welldocumented cauldrons are cut by a longitudinal graben. The South Pyramid fault could be interpreted as the eastern margin of such a graben; a set of poorly defined faults approximately $3 \mathrm{~km}(2 \mathrm{mi})$ to the west may form its western margin.

Between the Rainbow and Pinkey Wright-Elephant Back fault zones, the structure of the inner cauldron is relatively simple. An outcrop belt of pre-caldera rocks (andesite of Holtkamp Canyon) marks the axis of the resurgent(?) arch; caldera fill (tuff of Woodhaul Canyon) dips gently away on either side. The caldera fill is over $425 \mathrm{~m}(1,400 \mathrm{ft})$ thick. The Holtkamp CanyonWoodhaul Canyon contact is the caldera floor. South of the Pinkey Wright-Elephant Back fault zone, rocks of the Muir cauldron are covered by rocks of the Rimrock Mountain group. The base of the Rimrock Mountain group is next exposed in the Threemile Hills, where rocks related to the Muir cauldron are absent. The south and southwest caldera wall must run between the Pinkey Wright-Elephant Back fault and the Threemile Hills. The inferred China Pond fault has approximately the right position; it also marks the border between complex structures in the southern end of the Pyramid Mountains and simpler structures of outlying hills.

North of the Rainbow fault, structures are much more complicated. The tuff of Woodhaul Canyon thins and increasingly takes on the aspect of a calderacollapse megabreccia, in the sense of Lipman (1976). The caldera apparently became enlarged toward the north by slumping, beginning during eruptions of the tuff of Woodhaul Canyon. The northern end of the caldera collapsed during eruption of the tuff of Graham Well; the tuff of Woodhaul Canyon is absent there. The scalloped outcrops of tuff of Graham Well are intercalated with slices of andesite of Holtkamp Canyon that seem to have slid off the northern segment of the caldera wall. The area north of the Jose Placencia fault zone seems to be outside the inner cauldron; neither the tuff of Woodhaul Canyon nor the tuff of Graham Well extend into it.

The three successive ring-fracture zones, marked by alignment of felsic domes, are shown in fig. 7. Zone I (rhyolite of Jose Placencia Canyon) formed before eruption of tuff of Woodhaul Canyon and caldera collapse; zone II (latite of Uhl Well) and zone III (rhyolite of Pyramid Peak) formed later. Zone I is overlapped slightly by the inner cauldron in the vicinity of Lightning Dock Mountain.

Only the northeast third of the ring-fracture zones is exposed; the rest is hidden under the Playas and Animas Valleys. In the oldest proposed cauldrons elsewhere in southwest New Mexico, ring-fracture domes and associated deposits developed on only one side. The Goodsight-Cedar Hills depression (Seager, 1973) and the Crosby Mountain depression (Bornhorst, 1976) are examples. Whether the Muir cauldron is another is not known.

Beyond the ring-fracture zone, rocks of the Muir cauldron (Pyramid Mountains volcanic complex) are absent. The ring-fracture zone extends only a short distance north of the mapped area. Its extent under the Playas Valley is unknown. In the Animas Valley, its outer limit must lie between the Threemile Hills and the 


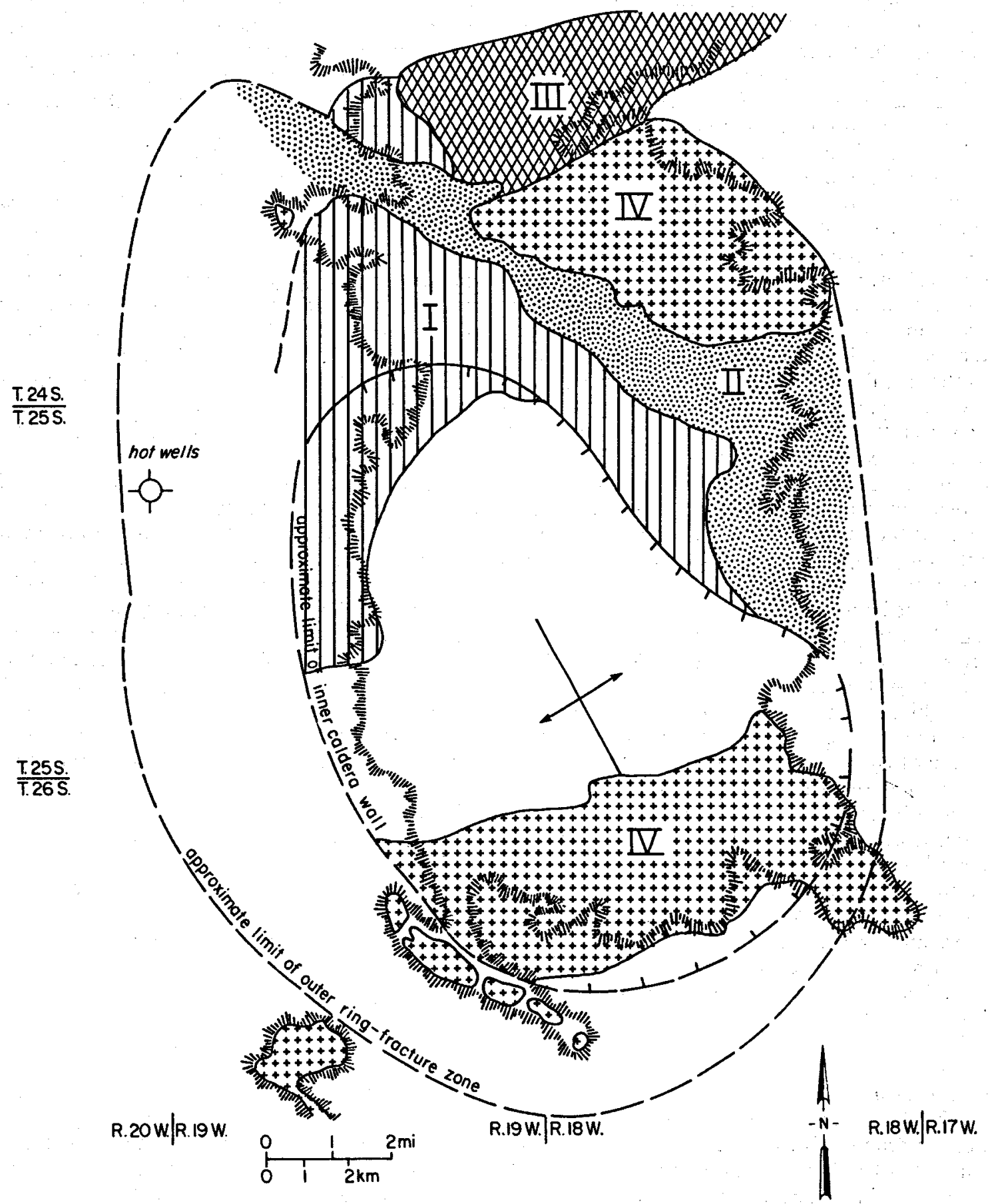

FIGURE 7-STRUCTURAL ELEMENTS OF MUIR CAULDRON; hachured line shows approximate limit of inner caldera fill (tuff of Woodhaul Canyon, tuff of Graham Well). Roman numerals denote successive zones of ring-fracture and moat development: I, (vertical lines) precollapse ring-fracture domes and flows of rhyolite of Jose Placencia Canyon; II, (stippled) postcollapse ring-fracture domes and flows of latite of Uhl Well; III, (cross hatched) postcollapse ring-fracture domes and flows of rhyolite of Pyramid Peak; IV, (crosses) ash-flow tuffs, sedimentary rocks, and mafic lava flows of post-cauldron Rimrock Mountain group, largely preserved in cauldron moat.

Pyramid Mountains, and between the small hills of unassigned rhyolite and Paleozoic limestone near Table Top Mountain and the Pyramid Mountains. Projected north, the outer limit of the ring-fracture zone continues toward the hot wells of the Lightning Dock KGRA.

AGE OF MUIR CAULDRON-The K-Ar dates reported by P. E. Damon and M. Shafiqullah (Deal and others, 1978) suggest that the Muir cauldron developed between
37 and 36 m.y. ago (early Oligocene), which places it among the oldest known cauldrons in New Mexico. The upper part of the tuff of Woodhaul Canyon, the main cauldron fill, was dated at $36.8 \pm 0.8 \mathrm{~m}$.y. The latite of Uhl Well, a ring-fracture rock, was dated at $36.6 \pm 0.8$ m.y. The ages of $35.8 \pm 0.8$ and $34.2 \pm 0.6 \mathrm{~m} . \mathrm{y}$. for tuffs 2 and 6 of the post-cauldron Rimrock Mountain group place a younger limit on the Muir cauldron. 


\section{Post-Oligocene structures}

Many faults of the Pyramid Mountains displace rocks of the Rimrock Mountain group; these faults were active after the formation of the Muir cauldron. This period of faulting cannot be dated locally, but elsewhere in southwest New Mexico, cauldron structures were reactivated by early stages of basin-and-range faulting. Where dated, basin-and-range faulting began about 21 m.y. ago and only minor movements occurred after 6 m.y. B.P. (Elston and others, 1973).

All rocks and structures of the Pyramid Mountains are truncated abruptly by north-trending faults on both sides of the range. Movement on these faults resulted in the present basin-and-range topography. On the east side of the Animas Valley, the Animas Valley fault, which cuts Quaternary piedmont deposits, has already been described. The hot waters of the Lightning Dock KGRA seem to be controlled by the intersection of this fault and the ring-fracture zone of the Lightning Dock KGRA. This and other Quaternary faults of the Animas Valley were described in more detail by Reeder (1957) and Gillerman (1958).

\section{Other possible subsurface structures of Animas Valley}

Elsewhere we have raised the question of whether a mid-Tertiary cauldron could be centered on the central Peloncillo Mountains between I-10 and US-80, west of the Lightning Dock KGRA (Deal and others, 1978). If so, its ring-fracture zone could pass through the geothermal anomaly. This question has not yet been resolved. Geologic maps of parts of the Peloncillo Mountains have been published by Drewes and Thorman $(1980 \mathrm{a}, \mathrm{b})$, but work on adjoining parts of the range by personnel of the U.S. Geological Survey, several graduate students, and ourselves is still incomplete.

\section{Regional distribution of basalt younger than $7 \mathrm{~m} . \mathrm{y}$.}

Because geothermal systems are commonly associated with active or recently active volcanism, we searched for evidence of Pliocene-Pleistocene volcanic activity in the vicinity of the Lightning Dock KGRA but failed to find any. However, evidence for minor but widespread post7-m.y. basaltic volcanism elsewhere in Hidalgo County (fig. 8) is growing.

In the San Luis Pass area at the southern end of the Animas Mountains (latitude $31^{\circ} 23^{\prime} 30^{\prime \prime}$. N., longitude $108^{\circ} 44^{\prime} 38^{\prime \prime}$ W.), a porphyritic basalt was dated at $6.8 \pm 0.2$ m.y. (Deal and others, 1978). In the northern Peloncillo Mountains (latitude $32^{\circ} 18^{\prime} 2^{\prime \prime}$ ' N., longitude $109^{\circ} 01^{\prime} 45^{\prime \prime} \mathrm{W}$.), small plugs and cinder cones mapped by Drewes and Thorman (1980a) were dated at $6.1 \pm 0.2 \mathrm{~m} . \mathrm{y}$. (Marvin and others, 1978). Dikes of similar lithology at the northern end of the Pyramid Mountains (SE $1 / 4$ SW $1 / 4$ sec. 9 and SW $1 / 4$ NW $1 / 4$ sec. 16, T. 23 S., R. 18 W.) were assumed to be of similar age by Thorman and Drewes (1978)

A basalt cone on the west side of the Animas Valley (latitude $31^{\circ} 57^{\prime} \mathrm{N}$., longitude $108^{\circ} 52^{\prime} \mathrm{W}$.) was the site of the young eruption closest to the Lightning Dock KGRA. The cone's rocks were dated at $0.14 \pm 0.02$ m.y. (Marvin and others, 1978). Lava from this cone flowed northward for approximately $19 \mathrm{~km}(12 \mathrm{mi})$; two samples collected along NM-9, west of Animas, yielded dates of $0.51 \pm 0.03$ m.y. (Deal and others, 1978) and $0.54 \pm 0.05$ m.y. (Lynch, 1978), respectively.

The U.S. Geological Survey geologic map of New Mexico (Dane and Bachman, 1965) shows a patch of Quaternary basalt off the western foot of the Peloncillo Mountains, in the San Simon Valley, just east of Rodeo, New Mexico. As far as we know, no description has ever been published. We examined this occurrence and found it to be an olivine-bearing basalt flow that issued from a spatter cone in NE $1 / 4$ sec. 32, T. $28 \mathrm{~S}$., R. $21 \mathrm{~W}$. The flow lies on young alluvial-fan deposits but is partly

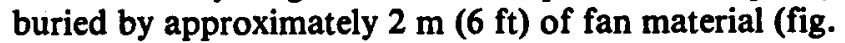
9). Four more basalt cinder cones and associated flows not shown by Dane and Bachman (1965) were found approximately $9 \mathrm{~km}(6 \mathrm{mi})$ farther south, in $W 1 / 2 \mathrm{sec}$. 30 , T. 29 S., R. 21 W. Their state of degradation suggests that they are Pleistocene, not Holocene. The rocks seem to be alkali basalt. These vents near Rodeo form a link between the Animas Valley flow and the large San Bernardino basalt field in the southeast corner of Arizona, for which Lynch (1978) reported ages between $3.3 \pm$ 0.12 and $0.27 \pm 0.05$ m.y. A northeast-trending line drawn from the southern end of the San Bernardino field to the Animas cone, via the Rodeo centers, is 75 $\mathrm{km}(45 \mathrm{mi})$ long. If projected another $30 \mathrm{~km}(18 \mathrm{mi})$ it would reach the hot wells of the Lightning Dock KGRA. In chapter II of this circular, geochemical evidence will be presented for a geothermal anomaly in the ground water of the Animas Valley, parallel to this line. In the area of the hot wells, magnetotelluric soundings have detected an electrically conductive body at a depth of $7 \mathrm{~km}(4 \mathrm{mi})$. Basaltic magma could be a possible interpretation of the anomaly, but other interpretations are possible (Jiracek, in Callender, 1981). At any rate, basaltic magma or basalt near the solidus should be considered as a possible ultimate heat source for the Lightning Dock KGRA.

\section{Mineralization}

Veins of several ages occur in the Pyramid Mountains. Northeast- and west-trending veins in secs. 1 and 2, T. 24 S., R. 19 W., are part of the Pyramid (or Leitendorf) subdistrict of the Lordsburg mining district, which has yielded between $\$ 550,000$ and $\$ 600,000$ in silver and copper (Elston, 1965). The veins were emplaced in the andesite of Shakespeare; the andesite of Gore Canyon is not known to be mineralized. Mineralization may be related to the Lordsburg granodiorite porphyry stock (Laramide).

A second period of mineralization seems to be associated with the formation of the Muir cauldron. Mineral production has been negligible. Pyritization is widespread in rhyolite of Jose Placencia Canyon and in tuff of Woodhaul Canyon, especially near their type localities. Veins carrying pyrite and traces of stibnite have been prospected in sec. 7, T. $25 \mathrm{~S}$., R. $18 \mathrm{~W}$. They were emplaced in andesite of Holtkamp Canyon and tuff of Woodhaul Canyon. In SE1/4 sec. 17, T. 25 S., R. 18 W., 


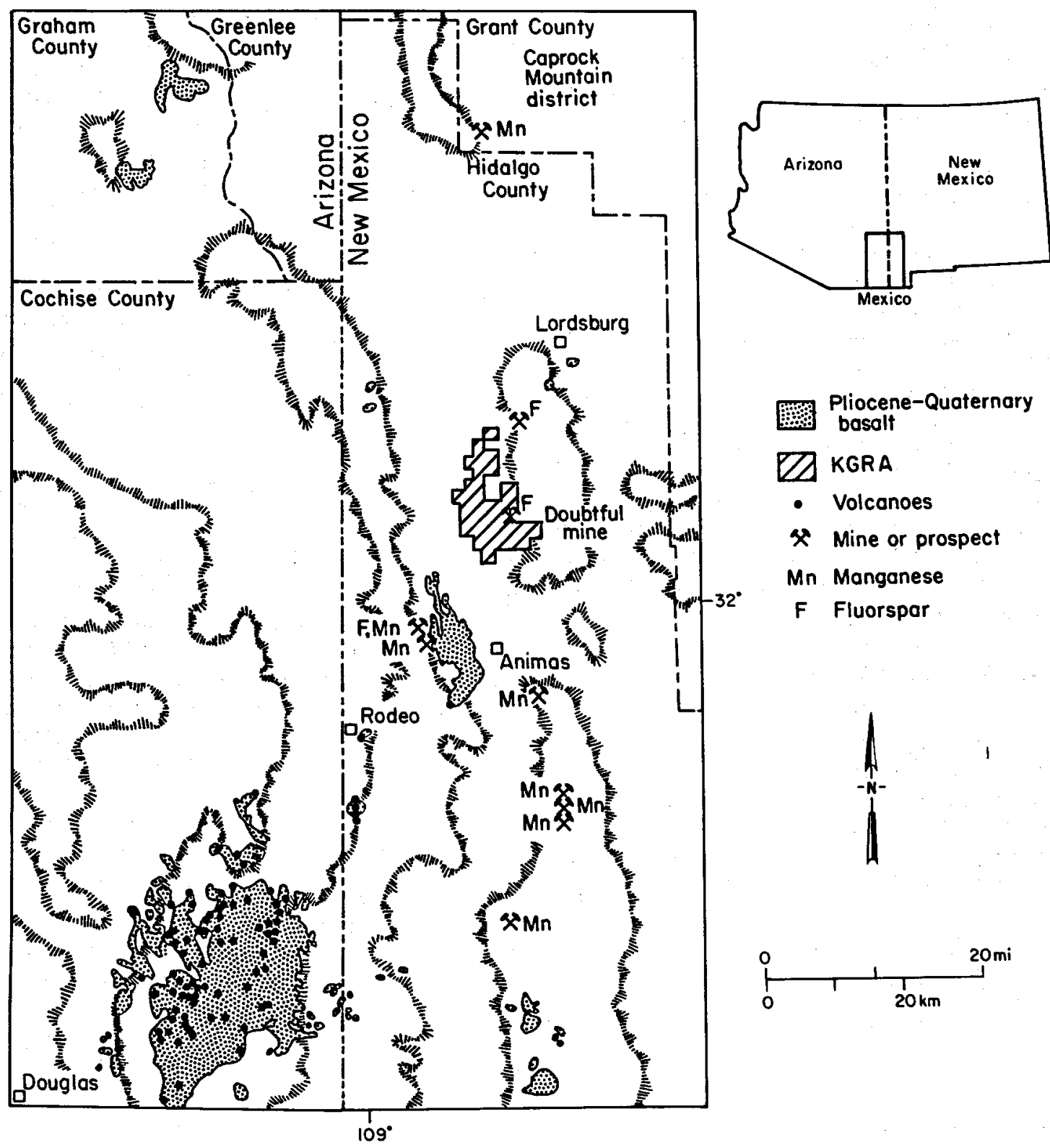

FIGURE 8-DistRIBUtion of PLIOCENE-PLEISTOCENE BASALT AND LOW-TEMPERATURE MANGANESE AND FLUORSPAR VEINS IN VICINITY OF LIGHTINING DOCK KGRA.

a northwest-trending vein has been prospected for copper and silver. The vein is controlled by a dike of rhyolite of Jose Placencia Canyon emplaced in andesite of Holtkamp Canyon. Copper stains occur at the margin of a northeast-trending rhyolite dike in SW1/4 sec. 2, T. 24 S., R. 19 W. Near the probable cauldron margin in $\mathrm{S}^{1} / 2$ sec. 23 , T. $25 \mathrm{~S}$., R. $18 \mathrm{~W}$., a northwest-trending fault controls a prominent quartz vein approximately $1.6 \mathrm{~km}$ (1.0 mi) long.

A third period of mineralization subsequent to, or concurrent with, later stages of basin-and-range faulting resulted in northwest- or north-trending veins carrying fluorite, psilomelane, black calcite, and white calcite (fig. 8). Within the mapped area they have been worked for fluorspar and are located in secs. 15 and 23, T. 25 S., R. 19 W., and in sec. 2, T. 24 S., R. 19 W. The Doubtful (or Animas) mine, at the foot of Lightning Dock Mountain in sec. 15, T. 25 S., R. 19 W., is the most important fluorspar property in the southwest corner of New Mexico (Rothrock and others, 1946). Past production has been small $(\$ 40,000-\$ 60,000)$, but General Chemical Corporation purchased the property after a drilling program. The mine is approximately 5 $\mathrm{km}(3 \mathrm{mi})$ east of the geothermal anomaly. Mineralization is probably Miocene or younger and may be related to the hydrothermal system that has been tapped in the Lightning Dock KGRA.

In the Leitendorf Hills, glassy zones in the rhyolite of Pyramid Peak have been prospected for perlite.

\section{Geological and geophysical characteristics of Lightning Dock KGRA}

Prior to our work, indications were that the Lightning Dock geothermal anomaly might be the surface expres- 
- sion of a major high-enthalpy (vapor-dominated) geothermal system associated with young rhyolitic volcanism. Unfortunately, these indications have not been confirmed.

Specifically, rhyolite breccia encountered in the discovery well might incorrectly have been interpreted to be part of an active or recently active dome. In the nearby Pyramid Mountains, Flege (1959) described rhyolite necks, flows, and breccias (his North Pyramid rhyolite flows and South Pyramid rhyolite breccia), which he interpreted as having erupted after basin-and-range faulting and tilting. The flows were said to have been funneled down present-day valleys. If true, this would make the flows late Pliocene or younger. The published literature suggested that Pliocene-Pleistocene rhyolites thus might not be confined to the Pyramid Mountains. The map of Ballmann (1960) showed Quaternary rhyolite and dacite domes and flows in the Knight Peak area, some $40 \mathrm{~km}$ (24 mi) northeast of the Pyramid Mountains. The U.S. Geological Survey map of New Mexico (Dane and Bachman, 1965) rendered these rocks by the symbol Qv, used elsewhere in the state only for the ringfracture domes of the Valles caldera.

Widespread hydrothermal alteration in the Pyramid Mountains, the Quaternary basalt cone approximately $30 \mathrm{~km}(18 \mathrm{mi})$ southwest of the hot wells, and Holocene fault scarps in valley fill could have been cited as further evidence for the geological conditions favoring a major geothermal system.

In contrast, the the results of the present study can be summarized as follows:

1) no evidence exists for post-Oligocene rhyolitic volcanism in the vicinity of the Lightning Dock KGRA;

2) hydrothermal alteration occurred in two stages:

a) during collapse of the Muir cauldron in Oligocene time, unrelated to the present thermal anomaly, and

b) during activity of Miocene or younger hot springs and shallow vein-forming hydrothermal fluids (fig. 8);

3) Miocene and younger shallow low-temperature veins and deposits from extinct hot springs are widespread throughout the Animas Valley. The Lightning Dock geothermal activity may be a relict of this activity;

4) the Animas Valley and adjacent basins of the Basin and Range province show some of the characteristics of rifts (high heat flow, high seismicity, basaltic volcanism). The ultimate heat source may be deepseated basalt near the solidus. The Lightning Dock KGRA lies on the projection of a northeast-trending line that connects basalt volcanoes of the Bernardino field, the Rodeo area, and the Animas Valley, all of them less than $1 \mathrm{~m} . y$. old;

5) the northeast-trending lines of basalt centers are parallel to the trend of a thermal anomaly in ground water of the Animas Valley, detected by geochemical analyses (chapter II of this circular); and

6) deep fracturing related to the intersection of an active basin-and-range fault (Animas Valley fault) with the ring-fracture zone of the Muir cauldron (Oligocene) may provide a local conduit for thermal waters.

\section{Evidence against post-Oligocene rhyolite}

Evidence for youthful rhyolite activity has proved to be spurious. For some time the supposedly Quaternary volcanic rocks of the Knight Peak area have been known to be Oligocene (Elston, 1968). In the Pyramid Mountains, the rhyolite domes and flows around Pyramid Peak cited by Flege (1959) have been reinterpreted as outer ring-fracture domes of the Muir cauldron. The unconformity beneath them was interpreted as caused by collapse of the Muir cauldron, not by basin-andrange faulting. The "rhyolite breccia" around South Pyramid Peak has been reinterpreted as ash-flow-tuff caldera fill (the tuff of Woodhaul Canyon of this circular).

Although the rhyolite chips recovered from the McCants wells have not been definitely identified, the mineral assemblages of clasts are similar to assemblages in the Pyramid Mountains volcanic complex (Oligocene). The rock is unlikely to be modern.

The youngest dated siliceous volcanic rocks in Hidalgo County are about 22 m.y. old. A large rhyolite dike in the southern part of the Lordsburg quadrangle (latitude $32^{\circ} 16^{\prime}$ N., longitude $108^{\circ} 43^{\prime}$ W.) has a K-Ar age of $22.7 \pm 0.5$ m.y. (Deal and others, 1978). In the southern Animas Mountains and adjacent Animas Valley, the Double Adobe Latite of Zeller and Alper (1965) yielded fission-track dates of $22.3 \pm 1.4$ and $22.1 \pm 2.5$ m.y. (Erb, 1979).

\section{Age of hydrothermal alteration}

The rocks of the lower part of the Pyramid Mountains volcanic complex tend to be strongly altered, especially in Woodhaul Canyon, south of Lightning Dock Mountain. Alteration has not been studied in detail, but it has the aspect of fumarolic argillic alteration, common around volcanic centers. Most of it is confined to the tuff of Woodhaul Canyon and older rocks. Alteration seems to have been most intense during the first stage of eruption and collapse of the Muir cauldron, prior to eruption of the tuff of Graham Well. The alteration appears to be unrelated to the modern geothermal anomaly. Locally, a small amount of alteration is associated with the young hydrothermal veins described in the next section.

\section{Hydrothermal veins and extinct hot springs}

The Lightning Dock geothermal anomaly may be a remnant of a hydrothermal system that was once much more widespread. Many hot springs were active in post20-m.y. time on both sides of the Animas Valley, from the Gila River to at least $50 \mathrm{~km}(30 \mathrm{mi})$ south of the United States-Mexico border, a distance of approximately $200 \mathrm{~km}(120 \mathrm{mi})$. The evidence lies in numerous travertine deposits and calcite veins, some of which grade downward or laterally into formerly commercial veins of fluorspar or psilomelane (fig. 9). The mineral deposits have been described elsewhere in some detail (Rothrock and others, 1946; Elston, 1963, 1965; GarciaGutierrez and Garcia-Gutierrez, 1969). Fluorite has also been reported from cuttings from the Cockrell Corp. No. 1 Federal well, drilled in the Animas Valley in sec. 31, T. 24 S., R. 19 W. (see chapter II of this circular). 


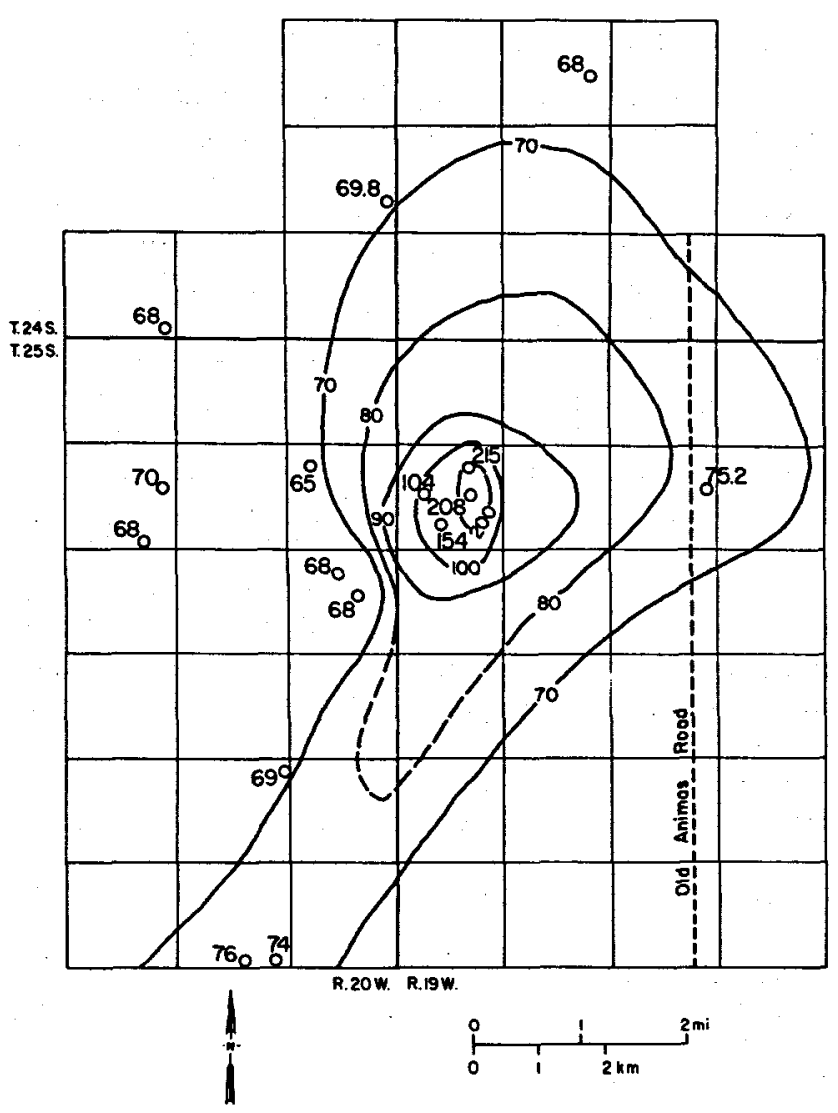

FIGURE 9-GROUND-WATER TEMPERATURES IN DEGREES FAHRENHEIT (Landsford and others, 1981).

The veins are shallow and geologically young. Throughout the Animas Valley, they generally trend north or northwest, parallel to the major basin-andrange faults. In the Caprock Mountain manganese district, at the northern end of the Animas Valley near the Gila River, veins were partly emplaced in Gila Conglomerate and intercalated lava flows, the Miocene and younger basin fill of this part of the Basin and Range province. The footwall of one of the veins, the Consolation, is a basaltic andesite dated at $20.9 \pm 0.5$ m.y. (Elston and others, 1973). A nearby vein, the Cliffroy, changes abruptly from opalized psilomelane to travertine a few meters below the present surface.

VEINS IN AND NEAR LIGHTNING DOCK KGRA-At the Doubtful (or Animas) mine, located at the foot of Lightning Dock Mountain, the fluorite-bearing veins grade laterally into banded calcite. An early generation of gray-and-white-banded, coarse calcite is cut by veins of black manganese-bearing calcite, which in turn have cores of late, coarse, white calcite. Although the banded calcite is not a true travertine spring deposit, nearsurface conditions are suggested by the fluid-inclusion studies described below. Southeast of the Doubtful mine, north of Woodhaul Canyon, a swarm of calcite veins has been found. Some vein zones are $60 \mathrm{~m}(200 \mathrm{ft})$

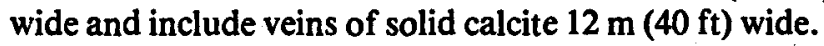

In the northern edge of the map area, in sec. 2, T. 24 S., R. 19 W., northwest-trending fluorite-calcite veins cut across northeast- and east-trending copper and silver veins of the Pyramid subdistrict of the Lordsburg mining district. The fluorite veins probably belong to the Miocene or younger period of mineralization.
FLUID-INCLUSION STUDIES-Fluid-inclusion studies were made on fluorite crystals from the Pyramid Mountains by T. J. Bornhorst and E. E. Erb in 1977 under the direction of G. P. Landis. The purpose was to determine temperatures of entrapment of fluids and to search for indications of boiling. The heating stage was built at the University of New Mexico by G. P. Landis and calibrated with organic and pure metal standards. Filling temperatures of inclusions were reproducible to $\pm 2^{\circ} \mathrm{C}$.

Fluid inclusions were measured in fluorites from the Doubtful mine. Some inclusions were $100 \%$ liquid, others were $100 \%$ gas, but a gas content of less than 30 volume $\%$ was most common. Apparent temperatures ranged from $137^{\circ} \mathrm{C}\left(279^{\circ} \mathrm{F}\right)$ to greater than $290^{\circ} \mathrm{C}$ $\left(550^{\circ} \mathrm{F}\right)$ in samples from the northern of two shafts and from $147^{\circ} \mathrm{C}\left(297^{\circ} \mathrm{F}\right)$ to greater than $349^{\circ} \mathrm{C}\left(660^{\circ} \mathrm{F}\right)$ in samples from the southern shaft. The wide range of temperatures and the occurrence of several types of primary inclusions suggests that the mineralizing fluid was boiling. The minimum temperatures approach the true temperature of entrapment. They were measured in inclusions with only a small amount of water.

Fluorite from veins in the Pyramid subdistrict yielded a narrow filling temperature range of $160-174^{\circ} \mathrm{C}(320$ $345^{\circ} \mathrm{F}$ ) (not corrected for pressure) for primary inclusions. The narrow range of temperatures, and uniformity in the type of inclusions, suggests that the liquid in these veins did not boil.

SUMMARY OF EVIDENCE RELATING VEINS TO THE GEOTHERMAL ANOMALY - No proof exists to show that the Lightning Dock geothermal anomaly is related to fluorite veins, but several indications suggest that it is possible:

1) the veins are geologically young (Miocene or younger);

2) the veins are geologically shallow;

3) the largest known concentration of veins is exposed in the bedrock nearest to the hot wells. Between the Doubtful mine and the hot wells, piedmont deposits cover all bedrock;

4) the thermal waters of the hot wells are anomalously high in fluorine (up to $12.6 \mathrm{ppm}$; see chapter II of this circular); the veins carry fluorite;

5) fluid-inclusion studies suggest that the vein-forming fluid was boiling, an indication of near-surface conditions; and

6) the temperature of formation of fluorite in the Doubtful mine $\left(137-147^{\circ} \mathrm{C} ; 249-297^{\circ} \mathrm{F}\right)$, measured by fluid-inclusion studies, was between the measured surface temperature of water from the McCants wells and the calculated subsurface temperature, determined by geochemical thermometry.

\section{Geophysical evidence for structural control of geothermal water}

Geochemical evidence cited in chapter II of this circular suggests that heated water of deep-seated origin is rising into the valley-fill sediments of the Animas Valley through a fault zone that cuts diagonally (with a northeasterly trend) across the valley. The hot wells lie at the northeastern end of this zone. There, hot water seems to rise to the surface in a local conduit formed by the intersection of the Animas Valley fault and the ring frac- 
- tures of the Muir cauldron. Another cauldron, centered on the Peloncillo Mountains to the west, may also have influenced structural control. The actual temperatures of ground water reported by Landsford and others (1981) confirm these interpretations (fig. 9). The anomaly centered on sec. 7, T. 25 S., R. 19 W. has an extension toward the southwest, parallel to the buried fault inferred to run diagonally across the Animas Valley. The pattern of ground temperatures is more complicated (fig. 10) but could be interpreted in the same manner.

The Animas Valley fault has surface expression; the northeasterly fault zone and the projection of the ringfracture zone of the Muir cauldron are inferred. Geophysical surveys lend credence to their existence. The
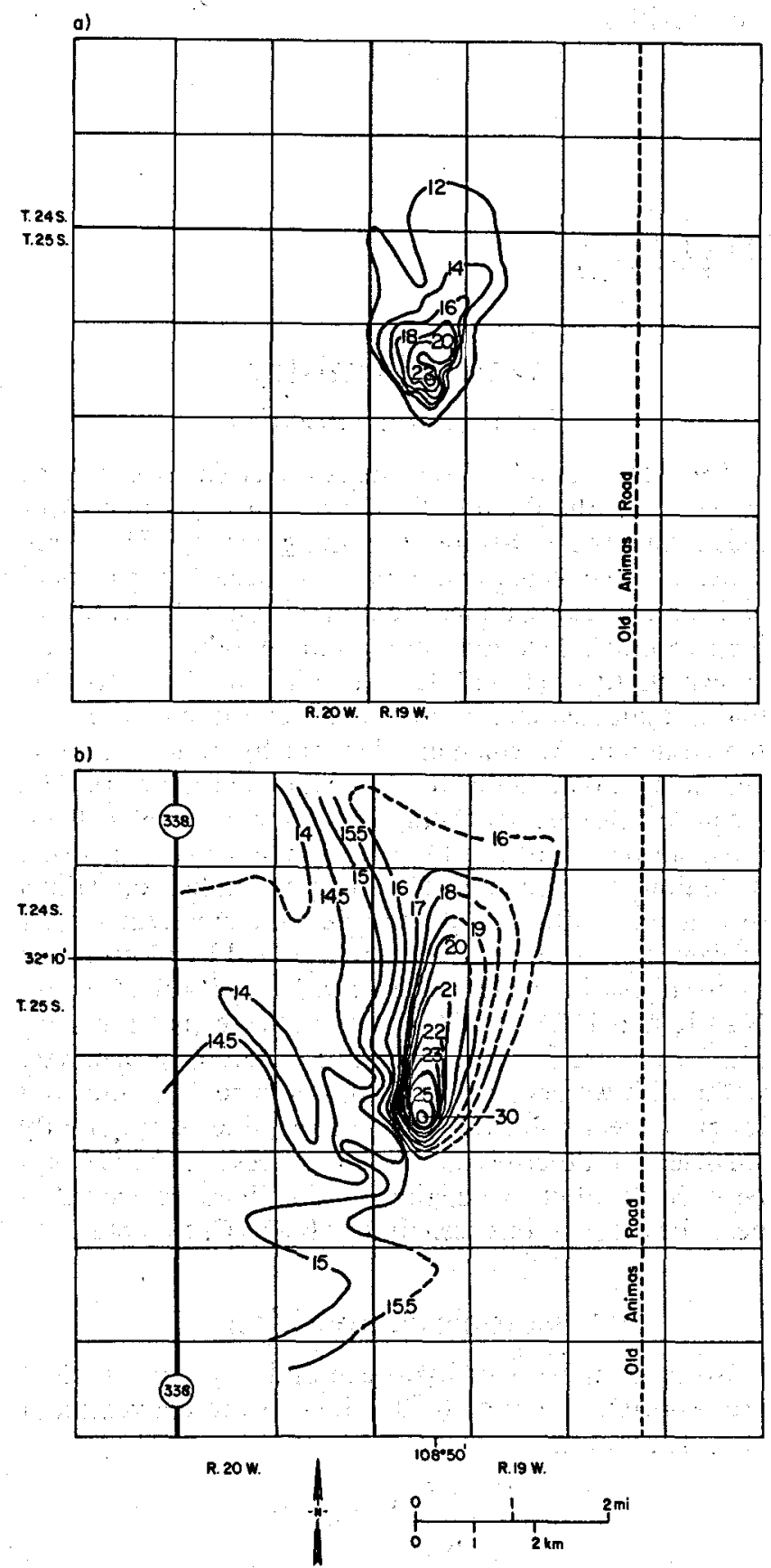

Figure 10-Temperature 1 m below land surface in Degrees Celsius (a; Kintzinger, 1956). Temperature $2 \mathrm{~m}$ below land surface in degrees Celsius, surveyed in April 1980 (b; Landsford and others, 1981). gravity study of Preslar (1976; map reproduced by Smith, 1978) and the electrical studies of G. R. Jiracek and associates (Jiracek and Smith, 1976; Smith, 1978; Jiracek, in Callender, 1981) show resistivity and gravity highs running from just east of Cotton City toward the area just south of the hot wells. These results correspond to the northeast trend of Quaternary basalt vents and geochemical anomalies of underground waters discussed in chapter II of this circular. A second gravity and resistivity high lies just east of the hot wells and trends north. This high has been interpreted as the expression of rhyolite domes in the buried ring-fracture zone of the Muir cauldron; the Animas Valley fault may also contribute to it. The immediate area of hot wells is characterized by low resistivity.

Jiracek and Smith (1976) summarized their conclusions as follows:

At Lightning Dock KGRA, the vicinity of the hot wells is expressed by small low-resistivity closures suggesting ascension of thermal waters in a conduit-like structure. This structure may have been produced by the intersection of a mid-Tertiary caldera ring-fracture and deflected, younger Basin and Range faults. Low resistivities mapped in the central portion of the valley are likely saline waters; however, a dipole-dipole sounding near the wells may have probed a deep hydrothermal reservoir.

In addition, Jiracek (in Callender, 1981) discussed the possible existence of a conductive body $7 \mathrm{~km}(4 \mathrm{mi})$ below the high-resistivity ridge at the hot wells, suggested by preliminary magnetotelluric soundings. A body of basaltic magma could be an explanation, but the data are not conclusive.

\section{Seismicity and heat flow}

Geothermal anomalies generally occur in areas of active volcanism, high heat flow, and active seismicity. While no evidence has been found for recently active silicic volcanism, the possibility of an extensive basaltic heat source has already been raised.

Fault scarps in Quaternary valley fill on both sides of the Animas Valley (geologic map, back pocket; Drewes and Thorman, 1980a) are evidence for seismic activity. The largest earthquake ever recorded in the western mountain region of North America occurred on May 3, 1887 (Modified Mercalli intensity VIII-IX). Its epicenter was near Baviste, Sonora, Mexico, latitude $31^{\circ}$ N., longitude $109^{\circ} \mathrm{W}$, about $30 \mathrm{~km}(18 \mathrm{mi})$ south of the common junction of New Mexico, Arizona, and Sonora (Coffman and von Hake, 1973). At present, the Lightning Dock area seems to be seismically inactive. Dellechaie (1977) recorded only one -1.0 magnitude earthquake during a 13-day microearthquake study. His analysis of 130 mine blasts during the 13-day period showed no anomalous velocity structures.

Anomalous heatflow in the Lightning Dock KGRA was first reported by Kintzinger (1956). His map (fig. 10a) indicated a local source for heated waters near the hot wells in sec. 7, T. 25 S., R. 19 W., and progressive dispersal and mixing with cold underground waters toward the north. A resurvey by Landsford and others (1981) showed that hot water had spread over a wider area since 1956 (fig. 10b), probably because cold ground water had been withdrawn by pumping on a large scale. 
Dellechaie (1977) interpreted his heat-flow data as follows:

Heatflow determinations from 31 observation holes reveal a $3 \mathrm{~km}$ elliptical anomaly in the area of the hot wells. Well depths averaged less than 70 meters.

The resulting anomaly encloses values as high as $\mathbf{2 0}$ HFU. The shape and size of the anomaly seems consistent with a point source of hot water localized by a fault intersection. Dispersion is compatible with the northerly ground-water flow. The northern-most observation holes exhibit very high gradients at shallow depths but become isothermal at depth.

\section{Current development of geothermal resources}

The Animas Valley is an important agricultural area; in 1981 geothermal water was used for heating 5 acres of commercial greenhouses in the winter. The owner, Thomas McCants of Cotton City, raises nearly 100 varieties of greenhouse plants; a lessee, Dale Burgett, raises long-stemmed roses. Four 30-m (100-ft) deep wells supply water at $101.5^{\circ} \mathrm{C}\left(215^{\circ} \mathrm{F}\right)$. The maximum amount needed is about $1,500 \mathrm{~L}$ ( $400 \mathrm{gal}$ ) a minute. After passing through a heat exchanger, the water is used for heating the McCants home and for watering the surrounding lawns. Cold water for irrigating the greenhouses is piped from a well $2.5 \mathrm{~km}$ (1.5 mi) distant.

After earlier trials, present operations began in 1977. According to McCants (personal communication, 1981), no noticeable change in the availability or temperature of the hot water has taken place and no problems have arisen with scale. He believes that hot water is available for considerable extension of the present activities.

\section{Geochemistry}

Fifty-five water samples were collected from wells under the supervision of C. A. Swanberg, New Mexico State University, as part of an initial geothermal investigation of the Animas Valley (Landis, 1976; Callender, 1981). The water chemistry was analyzed at New Mexico State University under the supervision of A. L. Bristol using standard analytical procedures (table 2 , in back pocket). The physicochemical properties of the waters were studied using WATEQF, a FORTRANIV computer program that calculates the inorganic chemical equilibrium of natural waters (Plummer and others, 1978). Geothermometry was calculated using GEOTHM, a FORTRAN computer program written specifically for this work. The computer programs are described and critically evaluated in Logsdon (1981). Possible alteration phases in the geothermal reservoir were determined by means of mineral-stability diagrams constructed after the methods of Helgeson and others (1969); the diagrams are discussed in detail in Logsdon (1981).

Oxygen-isotope analyses were performed on a standard 3-inch, $60^{\circ}$-sector Nier-type gas ratio mass spectrometer at the University of New Mexico. Data were interpreted graphically and numerically by means of a digital integrator interfaced to a minicomputer. Oxygen-isotope gas samples of the waters were prepared by the carbon dioxide-water equilibration method of Epstein and Mayeda (1953). The hydrogen-isotope analyses were performed on a 3-inch, $60^{\circ}$-sector Nier-type gas ratio mass spectrometer at the U.S. Geological Survey Isotope Branch laboratories in Denver, Colorado, by G. P. Landis. The hydrogen isotope samples were prepared by the reduction-of-water technique of Bigeleisen and others (1952). Details of the analytical procedures for both oxygen and hydrogen are given in Logsdon (1981). Precision of the oxygen analyses is better than \pm 0.2 permil; the precision of the hydrogen analyses is better than \pm 2 permil.

\section{Water chemistry Chemical composition}

The water samples from the Animas Valley comprise three suites, the P-suite (Pyramid), the AN-suite (Animas), and the LD-suite (Lightning Dock). The three suites were collected and named by three different field assistants working under the supervision of C. A. Swanberg. Sample locations are given in table 2 and are shown in figs. 11 and 12. Chemical analyses for the major aqueous species in the water samples are presented in table 3, which also lists the hydrogen and oxygen isotopic data and several calculated parameters. The results of the chemical analyses are shown graphically in the trilinear plot of fig. 13. The samples can be classified as sodium-bicarbonate waters with variable proportions of calcium, sulfate, and chloride. The apparent scatter of values in the diagram can be resolved by plotting the three suites of samples separately. In fig. 14 the $\mathrm{Ca}-\mathrm{Mg}$ $\mathrm{Na}+\mathrm{K}$ and $\mathrm{HCO}_{3}-\mathrm{Cl}-\mathrm{SO}_{4}$ plots indicate that the sample waters are mixtures of dilute sodium-bicarbonate water with waters rich in calcium and sulfate and, to a lesser degree, chloride. One mixing line is apparently sufficient to describe the mixing process in the $\mathrm{Ca}-\mathrm{Mg}$ $\mathrm{Na}+\mathrm{K}$ plot, but two distinct mixing lines are needed to describe the relations seen in the $\mathrm{HCO}_{3}-\mathrm{Cl}-\mathrm{SO}_{4}$ plot.

\section{Isotopic composition}

Isotopic analyses of hydrogen and oxygen in table 2 are reported as $\delta D$ or $d^{18} 0$ values in the conventional permil notation,

$$
\delta=\frac{\mathbf{R}_{\text {spl }}-\mathbf{R}_{\text {std }}}{\mathbf{R}_{\text {std }}} \times 10^{3},
$$

where $R_{\text {spl }}=\mathrm{D} / \mathrm{H}$ or ${ }^{18} 0 /{ }^{16} 0$ ratio in the sample and $R_{\text {std }}$ is the corresponding ratio in the standard. The 


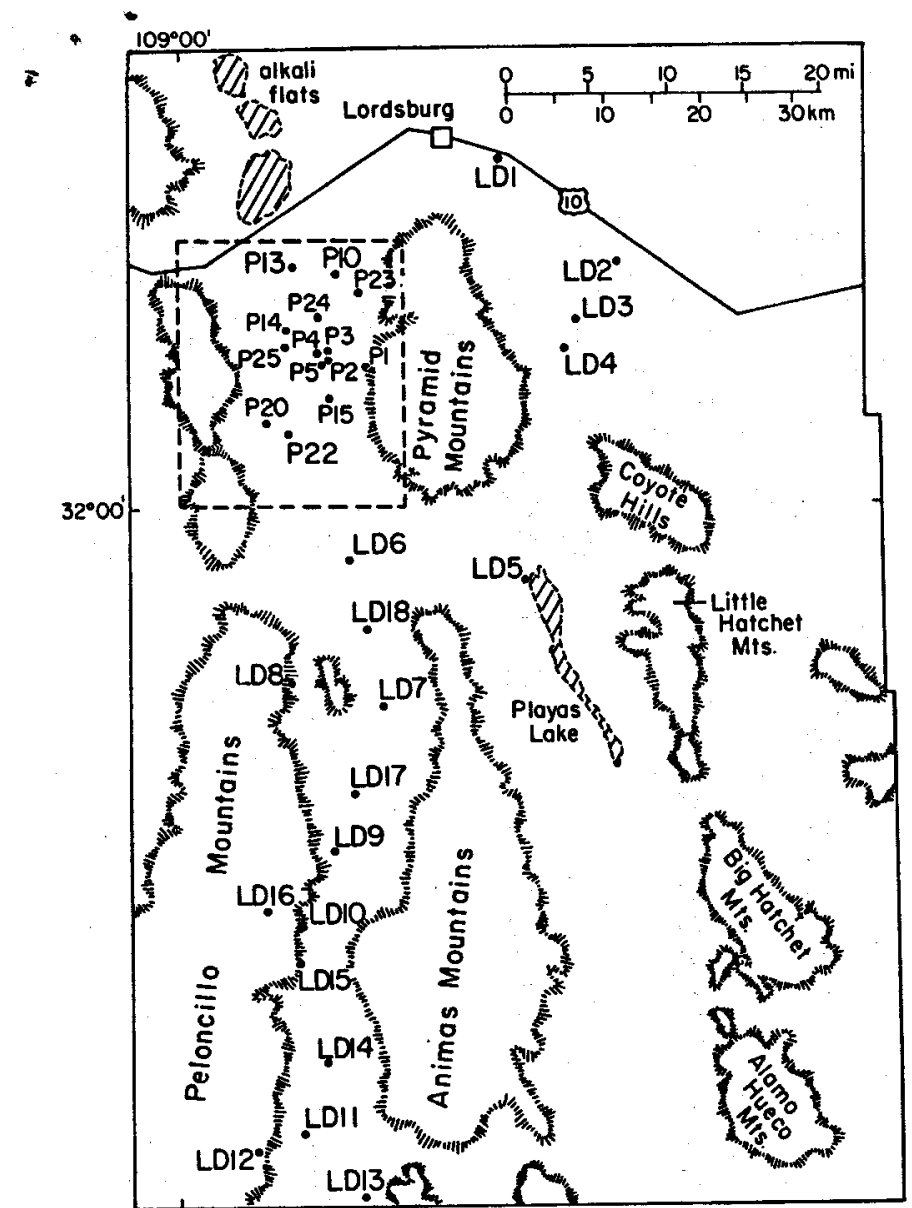

FIGURE 11-LOCATIONS OF P-SERIES AND LD-SERIES WATER SAMPLES IN animas and adjacent LoRdsburg and Playas Valleys; box shows location of fig. 12.

standard for both hydrogen and oxygen is Standard Mean Ocean Water (Craig, 1961).

The results of the Animas Valley stable isotope study are presented in table 2 . All ground-water samples are from relatively shallow (less than $40 \mathrm{~m}$ [130 ft] deep) wells. Since samples LD1-LD5 are from the adjacent Lordsburg and Playas Valleys, which probably are not in hydraulic continuity with the lower Animas Valley (Reeder, 1957), they will not be considered in this discussion. The P-series was chosen for analyses of both hydrogen and oxygen isotopes because the chemistry and the geologic setting of the samples indicated that they would yield the greatest amount of information about the geothermal system. Only oxygen-isotopic analyses are available for the LD-series, the cool, dilute waters of the upper Animas Valley.

The $\delta^{18} 0$ values of ground waters from the KGRA and adjacent parts of the lower Animas Valley range from -9.0 permil to -11.4 permil. Ground waters from the upper Animas Valley range from $\mathbf{- 8 . 1}$ permil to -10.1 permil. Summer rainwater has a $\delta^{180} 0$ value near -5 permil. $\delta D$ values for the lower valley ground waters range from -65 permil to -80 permil. The $\delta D$ of the summer rainwater is about $\mathbf{- 2 1}$ permil. Interpretation of these data is complex and requires some knowledge of the hydrology of the valley and of the meteorology of southwestern New Mexico.

The isotopic data for the P-series waters are plotted on a $d D-\delta^{18} 0$ diagram in fig. 15 ; the meteoric water line

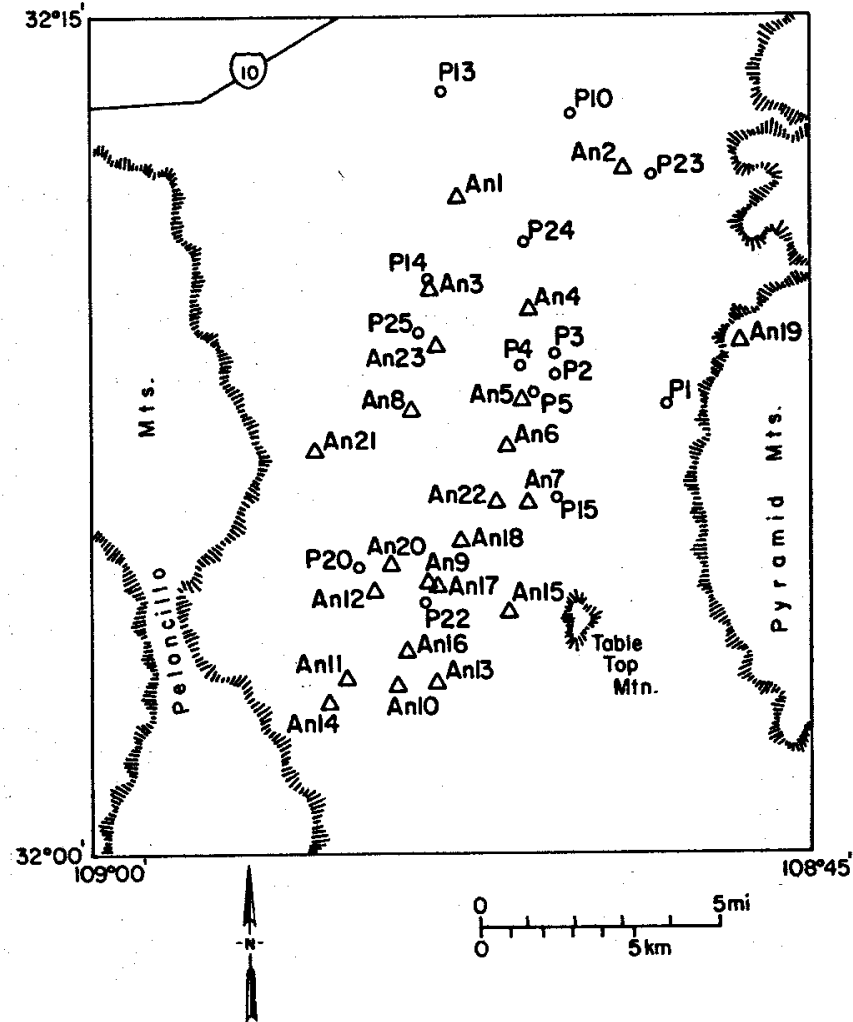

FIGURE 12-LOCATTONS OF P-SERIES (O) AND AN-SERIES ( $\Delta$ ) WATER SAMPLES IN LOWER ANIMAS VALLEY. Samples P2, P3, and P4 are from hot wells.

of Craig (1961) is plotted along with the data. Linear regression on the isotopic values yields an equation,

$$
\delta \mathrm{D}=7.51 \delta^{180}+3.3 \text {, }
$$

with a correlation coefficient of 0.8 . The ground waters of the Animas Valley, including the KGRA, are meteoric in origin.

While $50-60 \%$ of the precipitation in the Animas Valley falls during the summer rains (Reeder, 1957), the ground waters do not represent samples of the present-

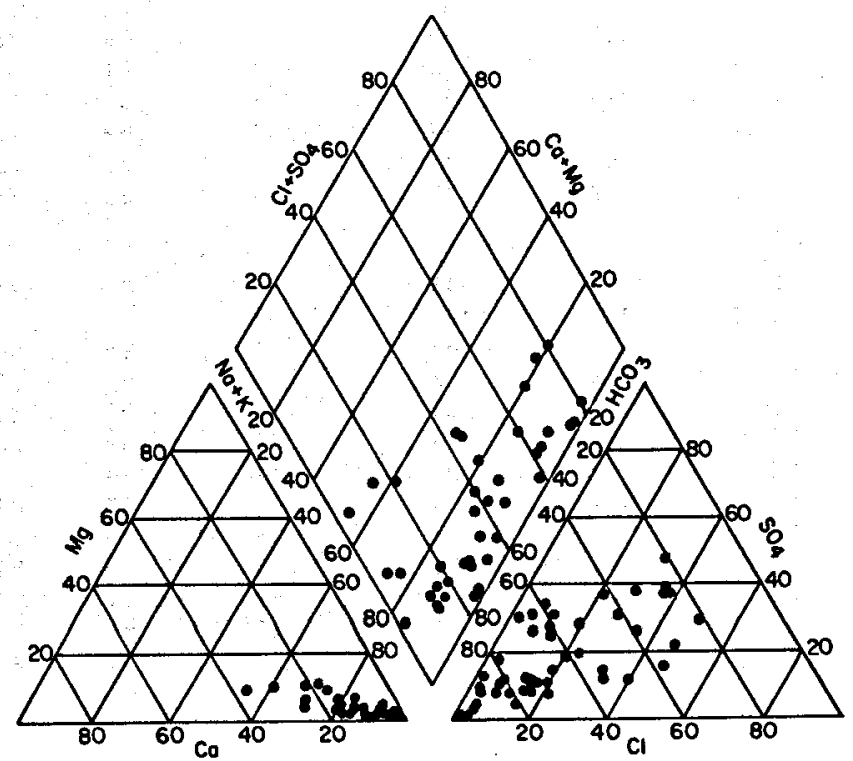

FIGURE 13-TRILINEAR PLOT OF WATER SAMPLES FROM ANIMAS VALLEY. Chemical analyses of water are represented as percentages of total equivalents per liter. 
TABLE 3 - COMPARISON OF RESERVOIR TEMPERATURES CALCULATED FOR GROUND WATERS OF ANIMAS VALLEY USING VARIOUS CHEMICAL GEOTHERMOMETERS. Na-K: sodium-potassium-geothermometer (Truesdell, 1976); Na-K-Ca (F\&T): sodium-potassium-calcium geothermometer using $\beta$ parameter of Fournier and Truesdell (1973); Na-K-Ca (UNM): sodium-potassium-calcium geothermometer using $\beta$ parameter of Landis and Logsdon (1980); Alpha Quartz: silica geothermometer for alpha-quartz solubility along liquid-vapor curve, and at 500, 1,500, and 2,000 bars (Walther and Helgeson, 1977); Alpha cristobalite: silica geothermometer for alpha-cristobalite solubility along liquid-vapor curve (Walther and Helgeson, 1977); Chalcedony: silica geothermometer using chalcedony solubility along liquid-vapor curve (Walther and Helgeson, 1977); "Best Estimate": subjective value based on rationalizing alkali and either alpha-quartz (L-V) or chalcedony models (Logsdon, 1981).

\begin{tabular}{|c|c|c|c|c|c|c|c|c|c|c|c|c|}
\hline \multirow[b]{2}{*}{ Sample } & \multirow{2}{*}{\multicolumn{2}{|c|}{ Na.K }} & \multirow{2}{*}{\multicolumn{2}{|c|}{$\begin{array}{c}\text { Na-K-Ca } \\
(\mathrm{FET})\end{array}$}} & \multirow{2}{*}{$\begin{array}{c}\text { Na-K-Ca } \\
\text { (UNM) }\end{array}$} & \multicolumn{4}{|c|}{ Alpha quartz (BARS) } & \multirow{2}{*}{$\begin{array}{c}\text { Alpha } \\
\text { cristobalite }\end{array}$} & \multirow[b]{2}{*}{ Chalcedony } & \multirow{2}{*}{$\begin{array}{c}\text { Best } \\
\text { Estimate }\end{array}$} \\
\hline & & & & & & L.V & 500 & 1500 & 2000 & & & \\
\hline \multicolumn{13}{|l|}{ P series } \\
\hline P 1 & & 109 & & 38 & 32 & 80 & 71 & 59 & 53 & 38 & 59 & 38 \\
\hline P 2 & & 169 & & 174 & 169 & 168 & 152 & 128 & 118 & 110 & 137 & 169 \\
\hline P 3 & & 164 & & 170 & 165 & 165 & 150 & 126 & 116 & 108 & 135 & 165 \\
\hline P 4 & & 153 & & 160 & 156 & 150 & 136 & 114 & 105 & 95 & 122 & 153 \\
\hline P 5 & & 129 & & 60 & 53 & 94 & 84 & 69 & 63 & 48 & 70 & 50 \\
\hline P 10 & & 85 & & 71 & 65 & 112 & 100 & 83 & 76 & 63 & 87 & 64 \\
\hline P 13 & & 112 & & 49 & 43 & 123 & 111 & 92 & 84 & 72 & 97 & 97 \\
\hline P 14 & & 128 & & 38 & 32 & 100 & 90 & 74 & 68 & 53 & 76 & 76 \\
\hline P 15 & & 129 & & 58 & 51 & 85 & 75 & 62 & 56 & 41 & 62 & 60 \\
\hline P 20 & & 101 & & 39 & 32 & 102 & 92 & 76 & 69 & 55 & 78 & 78 \\
\hline P 22 & & 102 & & 42 & 35 & 95 & 85 & 70 & 64 & 49 & 71 & 71 \\
\hline P 23 & & 73 & & 46 & 39 & 77 & 69 & 56 & 51 & 36 & 56 & 38 \\
\hline P 24 & & 152 & & 157 & 154 & 169 & 153 & 129 & 118 & 111 & 138 & 142 \\
\hline P 25 & & 137 & & 50 & 43 & 85 & 75 & 62 & 56 & 41 & 62 & 56 \\
\hline \multicolumn{13}{|l|}{ An series } \\
\hline An 1 & $\therefore$ & 126 & & 39 & 32 & 110 & 98 & 82 & 74 & 62 & 85 & 62 \\
\hline An 2 & & 85 & & 58 & 52 & 53 & 47 & 39 & 35 & 17 & 35 & 52 \\
\hline An 3 & & 131 & & 41 & 34 & 119 & 107 & 89 & 81 & 69 & 93 & 69 \\
\hline An 4 & & 130 & & 94 & 87 & 140 & 126 & 105 & 96 & 86 & 112 & 86 \\
\hline An 5 & & 139 & & 60 & 53 & 102 & 92 & 76 & 69 & 55 & 78 & 54 \\
\hline An 6 & & 132 & & 52 & 46 & 78 & 70 & 57 & 52 & 36 & 57 & 54 \\
\hline An 7 & & 117 & & 52 & 46 & 78 & 69 & 57 & 51 & 36 & 56 & 54 \\
\hline An 8 & & 133 & & 41 & 34 & 83 & 74 & 61 & 56 & 40 & 61 & 40 \\
\hline An 9 & & 117 & & 61 & 54 & - & - & - & - & - & - & 55 \\
\hline An 10 & & 116 & & 58 & 51 & 89 & 78 & 65 & 59 & 44 & 66 & 62. \\
\hline An 11 & & 129 & & 45 & 38 & 96 & 86 & 71 & 65 & 50 & 72 & 47 \\
\hline An 12 & & 122 & & 45 & 38 & 97 & 87 & 72 & 66 & 50 & 73 & 47 \\
\hline An 13 & : & 127 & & 64 & 57 & 81 & 72 & 59 & 54 & 39 & 59 & 58 \\
\hline An 14 & & 119 & & 45 & 38 & 96 & 86 & 71 & 65 & 49 & 72 & 47 \\
\hline An 15 & & 131 & & 44 & 37 & 78 & 70 & 57 & 52 & 37 & 57 & 37 \\
\hline An 16 & & 114 & & 48 & 41 & 88 & 78 & 64 & 59 & 44 & 65 & 46 \\
\hline An 17 & & 150 & & 81 & 73 & 78 & 70 & 57 & 52 & 36 & 57 & 80 \\
\hline An 18 & & 130 & & 45 & 38 & 89 & 78 & 65 & 59 & 44 & 66 & 45 \\
\hline An 19 & & 125 & & 30 & 23 & 91 & 81 & 67 & 62 & 46 & 68 & 60 \\
\hline An 20 & & 128 & & 39 & 32 & 101 & 91 & 75 & 69 & 54 & 77 & 70 \\
\hline An 21 & & 141 & & 49 & 42 & 89 & 78 & 65 & 59 & 44 & 66 & 60 \\
\hline An 22 & & 103 & & 48 & 41 & 82 & 73 & 60 & 55 & 39 & 60 & 55 \\
\hline An 23 & & 127 & & 42 & 35 & 88 & 78 & 64 & 59. & 44 & 65 & 43 \\
\hline \multicolumn{13}{|l|}{ LD series } \\
\hline LD 1 & & 133 & & 143 & 139 & 83 & 74 & 61 & 56 & 40 & 61 & 87 \\
\hline LD 2 & & 150 & & 151 & 100 & 91 & 81 & 67 & 61 & 46 & 68 & 95 \\
\hline LD 3 & & 199 & & 62 & 54 & 95 & 85 & 70 & 64 & 49 & 71 & 52 \\
\hline LD 4 & & 58 & $\therefore$ & 58 & 52 & 82 & 72 & 60 & 54 & 39 & 60 & 58 \\
\hline LD 5 & & 100 & & 95 & 88 & 99 & 89 & 73 & 67 & 52 & 75 & 93 \\
\hline LD 6 & & 171 & & 36 & 29 & 89 & 79 & 65 & 60 & 45 & 66 & 45 \\
\hline LD 7 & r. & 220 & & 21 & 14 & 99 & 89 & 74 & 67 & 53 & 75 & 53 \\
\hline LD 8 & & 154 & & 19 & 12 & 97 & 87 & 72 & 66 & 50 & 73 & 50 \\
\hline LD 9 & & - & & 45 & 36 & 99 & 98 & 74 & 67 & 53 & 75 & 45 \\
\hline LD 10 & & - & & 58 & 49 & 91 & 81 & 67 & 61 & 46 & 67 & 48 \\
\hline LD 11 & & 225 & & 70 & 62 & 104 & 93 & 77 & 71 & 58 & 80 & 60 \\
\hline LD 12 & & 289 & & 50 & 42 & 86 & 76 & 63 & 58 & 42 & 64 & 42 \\
\hline LD 13 & & 250 & & 56 & 49 & 91 & 81 & 67 & 61 & 46 & 67 & 48 \\
\hline
\end{tabular}



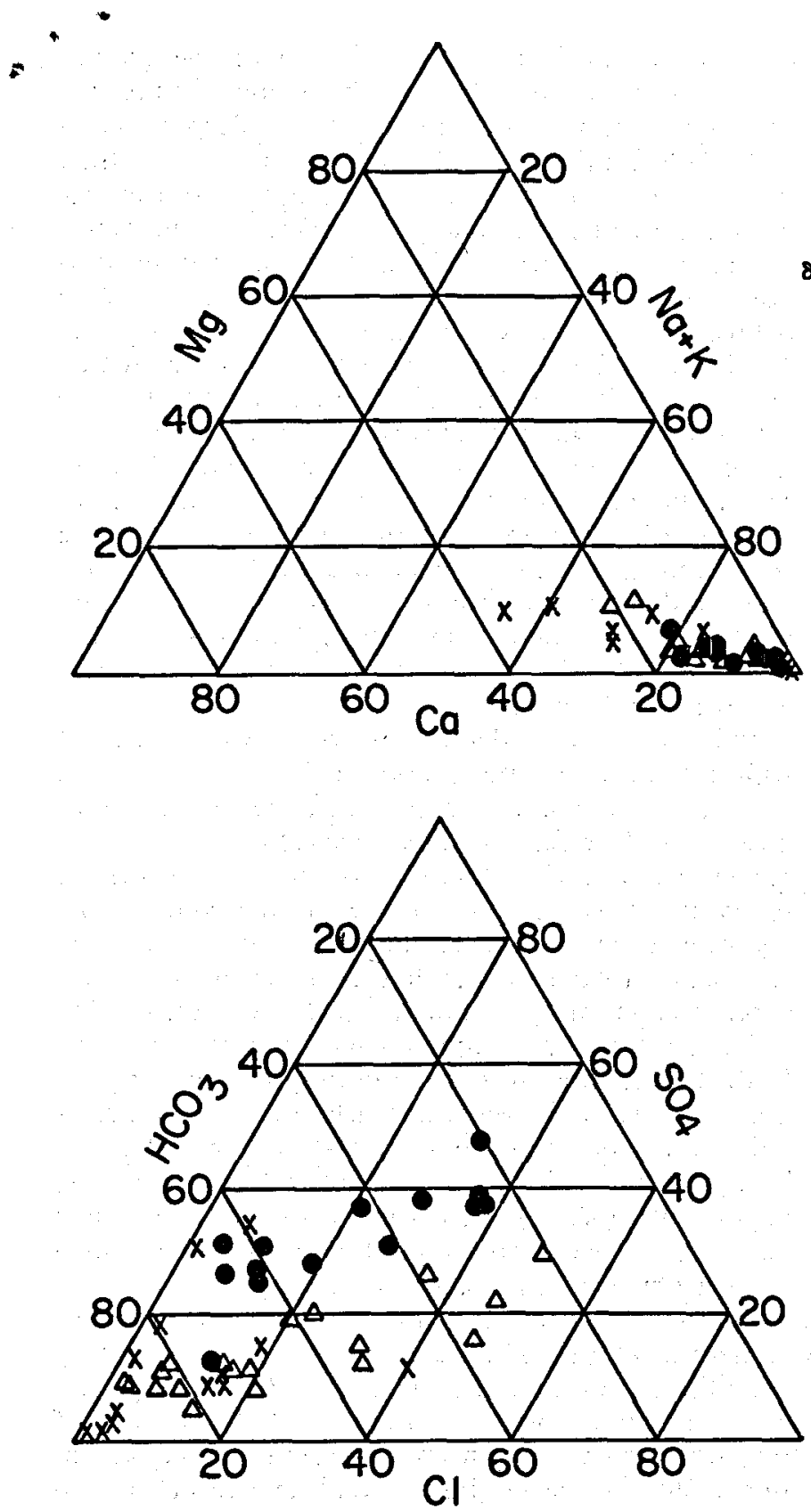

FIGURE $14-\mathrm{CA}-\mathrm{MO}-\mathrm{NA}+\mathrm{K}$ AND $\mathrm{HCO}_{3}-\mathrm{CL}_{-} \mathrm{SO}_{4}$ PLOTS FROM FIG. 5 WTTH P-SERIES $(\bullet$, LD-SERIES $(X)$, AND AN-SERIES $(\Delta)$ WATERS PLOTTED SEPARATELY:

day summer rains. This paradox is not hard to resolve. Typical summer rainstorms are high-intensity, shortduration convective storms. Rain that falls on the valley floor is unlikely to add significantly to recharge because the valley floor is an area of net discharge because of high rates of evapotranspiration and low rates of infiltration resulting from the presence of a caliche hardpan (Reeder, 1957; D. B. Stevens, personal communication, 1980). Much of the rain that falls on recharge areas in adjacent mountains during high-intensity storms runs off to playas on the valley floor and is lost by evapotranspiration. The principal source of meteoric water recharge to the Animas Valley is believed to be winter precipitation that falls in the surrounding mountains, as

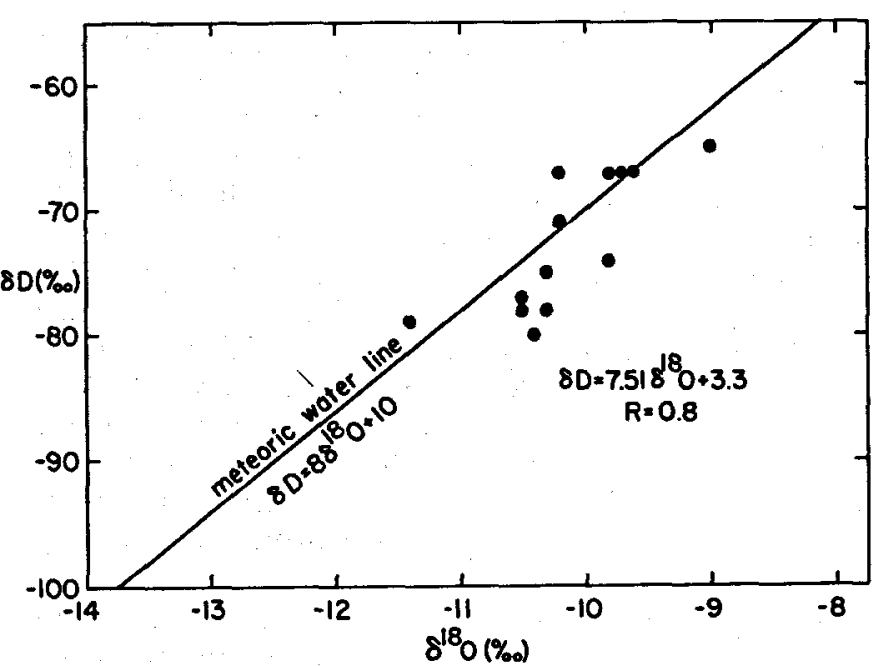

FIGURE $15-\delta D$ AND $\delta^{18} \mathrm{O}$ VALUES FOR P-SERIES WATERS; meteoric water line is from Craig (1961).

is the case in other southwest valleys (Wells, 1977). Winter storms are typically frontal storms of relatively long duration. Because of lower temperature of condensation, winter precipitation should have more negative $\delta \mathrm{D}$ and $\delta^{18} 0$ values than the summer rains, and proportionally more of the precipitation should infiltrate to the water table because of lower evaporation rates. This hypothesis is supported by a detailed study of the Tucson Valley in southern Arizona (Simpson and others, 1972). Samples P13, P14, and $P 22$ are cool, dilute waters with tightly grouped $\delta D$ and $\delta^{18} 0$ values (-67 permil and -9.6 permil) that can be taken as representative of effective modern meteoric recharge water. The deuterium value agrees very closely with the regional study of Taylor (1974).

Typical ground waters of the Animas Valley are present in unconfined aquifers in poorly consolidated valley-fill sediments. Locally, perched or confined conditions caused by clay lenses in the playa deposits of Pleistocene Lake Animas are encountered (Reeder, 1957). Most of the wells in the upper Animas Valley supply water from shallow, perched aquifers (Reeder, 1957). Ground-water samples that have $\delta^{18} 0$ values near -9.6 permil and $\delta D$ values near -67 permil represent samples from shallow aquifers recharged by modern meteoric waters. $\delta^{18} 0$ values that are significantly more positive than -9.6 permil may represent modern meteoric water that has undergone evaporation before or during infiltration.

Waters that have $\delta^{18} 0$ and $\delta D$ values significantly more negative than -9.6 permil and -67 permil, respectively, present more complex and problematical histories. Analysis of the chemical, isotopic, and temperature data indicates that a negative correlation exists between $\delta^{18} 0$ and $\delta D$ values and subsurface temperature, concentration of chlorine, and concentration of boron (Logsdon, 1981). The deeper, high-temperature reservoir water is more depleted in ${ }^{18} 0$ and $D$ than the shallow aquifer water. This is a surprising result because a higher temperature should favor increased ${ }^{18} 0 \mathrm{ex}-$ change with the enclosing rock and a shift to more positive $\delta^{18} 0$ values with essentially constant $\delta D$ values 
(Craig, 1963). Instead of the expected oxygen-shift pattern, the isotopic data of fig. 15 may represent a mixing line between a modern meteoric water $\left(\delta^{18} 0=-9.0\right.$ permil; $\delta D=-65$ permil) modified by evaporation and a deep reservoir water $\left(\delta^{18} 0=-13.4\right.$ permil; $\delta D=-97$ permil) with a small oxygen shift for the hot wells accounting for much of the scatter in the data. The small oxygen shift, approximately 0.5 permil, is similar to that observed at Wairakei and Long Valley (Mariner and Willey, 1976) and probably indicates that the Animas Valley geothermal system is moderately to very old, probably on the order of $10,000 \mathrm{yrs}$, and has isotopically well-flushed conduits. This interpretation is consistent with the observed record of hydrothermal activity in the region.

INTERPRETATION-The isotopic value of the deep water is substantially too negative to be the result of locally derived meteoric water. At least three reasonable interpretations exist for the very negative $\delta^{18} 0$ and $\delta D$ water required by the data:

1) The reservoir water may be ancient meteoric water trapped within the deep gravels or even within the fractured volcanic rocks below the valley fill. If such a water were representative of a colder climate than the present, it would have more negative isotopic values than modern waters. Such ancient waters have been described from arid and semiarid regions (Gat and Dansgaard, 1972; Gat and Issar, 1976) and have been proposed for the geothermal system at Yellowstone (Truesdell and others, 1977). Deep-circulation times for many geothermal systems have been estimated at more than 30,000 yrs (for example, Craig, 1963; Elder, 1976). For a steady-state model of the Animas Valley, given known recharge rates and porosities based on geologic and geophysical evidence, the residence time for basin waters is between 5,000 and 50,000 yrs. Therefore, Pleistocene water is probably present in the deeper portions of the basin. However, it has not been established that ancient meteoric waters in this portion of North America, at least as far back as about 20,000 yrs B.P., had isotopic values more negative than modern meteoric water. Although no data are available from southwest New Mexico, studies of the $\delta \mathrm{D}$ of cellulose in trees elsewhere in North America suggest that average annual meteoricwater isotopic values were probably little different from modern values, except in areas very close to the margins of the Pleistocene ice sheets (C. J. Yapp, University of New Mexico, personal communication, 1980).

2) The isotopically depleted waters may represent ground-water recharge from a climate with a significantly higher percentage of winter precipitation than prevails today. Paleobotanical studies of ancient packrat middens indicate that woodland communities were present in most of the Chihuahuan, Sonoran, and Mojave Deserts during the late Wisconsinan, 22,000-11,000 yrs B.P. (Van Devender and Spaulding, 1979). On the basis of the paleobotanical evidence and model water budgets for playa lakes, Van Devender and Spaulding (1979) propose that the late Wisconsinan climate in the Southwest was characterized by mild, wet winters and cool summers and that winter precipitation probably predominated until 8,000 yrs B.P. Simple mass-balance considerations indicate that as the fraction of winter precipitation in the total ground-water recharge ap- proaches 1, the isotopic composition of the ground water approaches the value of the winter component. This mechanism would produce older, deeper waters with significantly more negative isotopic values than modern waters only if summer precipitation were an important part of the recharge to modern ground water. The relative proportions of winter and summer infiltration, not precipitation, are the factors that determine the weighted isotopic composition of the ground water. As discussed above, modern ground water is dominated by winter precipitation, and a shift to relatively more winter precipitation probably would have little effect on the isotopic composition of the water. Furthermore, cooler summers would imply lower evaporation rates and more infiltration of summer precipitation. While such summer meteoric waters would be more negative than modern summer rainwater, they would be more positive than modern winter precipitation and would tend to offset the increased proportion of negative winter precipitation in the mixture.

3) The isotopically depleted waters may be associated with a condensed-vapor phase on the distal edge of a boiling geothermal system in which the isotopic composition of the reservoir water is close to that of modern meteoric water. Hot waters originating in geothermal reservoirs at temperatures above surface boiling must lose heat as they ascend. The heat loss may take place by conduction to the surrounding rock, by mixture with cooler waters, or by loss of steam. Conductive cooling will not affect the isotopic composition of the water. With the assumption that the initial isotopic composition of the reservoir water is nearly the same as that of modern meteoric water, mixing also will not affect the isotopic composition of the sample waters. However, below $220^{\circ} \mathrm{C}\left(428^{\circ} \mathrm{F}\right)$ water (vapor) is depleted in both $\mathrm{D}$ and ${ }^{18} 0$ relative to water (liquid), indicating that boiling followed by condensation of the vapor phase would explain the observed depletion. The potential isotopic consequences of boiling and recondensation are very complex (Truesdell and others, 1977; C. J. Yapp, personal communication, 1980) and beyond the scope of this circular. Uncertainties concerning initial conditions, mechanisms of boiling and condensation, and degree of post-condensation mixing make quantitative evaluation of the possibilities difficult. However, I have shown elsewhere that boiling and subsequent condensation of the vapor phase of the Lightning Dock geothermal system is consistent with the isotopic data, given reasonable physical assumptions (Logsdon, 1981).

In summary, the isotopic composition of hydrogen and oxygen in the waters of the Animas Valley indicates that the ground waters originated as meteoric water that may have been modified by evaporation and mixing. On the basis of present geochemical and geologic data and isotopic systematics, choosing unequivocally between the old-cold-water and boiling-condensation hypotheses is impossible; however, boiling and condensation are more likely to have played a role.

In fig. 16 the $\delta^{18} 0$ values for the P-series samples are plotted and contoured on a sketch map of the lower Animas Valley. Although data points are few, the $\delta^{18} 0$ isopleths trend northeast with apparent dispersion north of the hot wells. A plot of $\delta D$ values would give a similar pattern (Craig, 1961). 


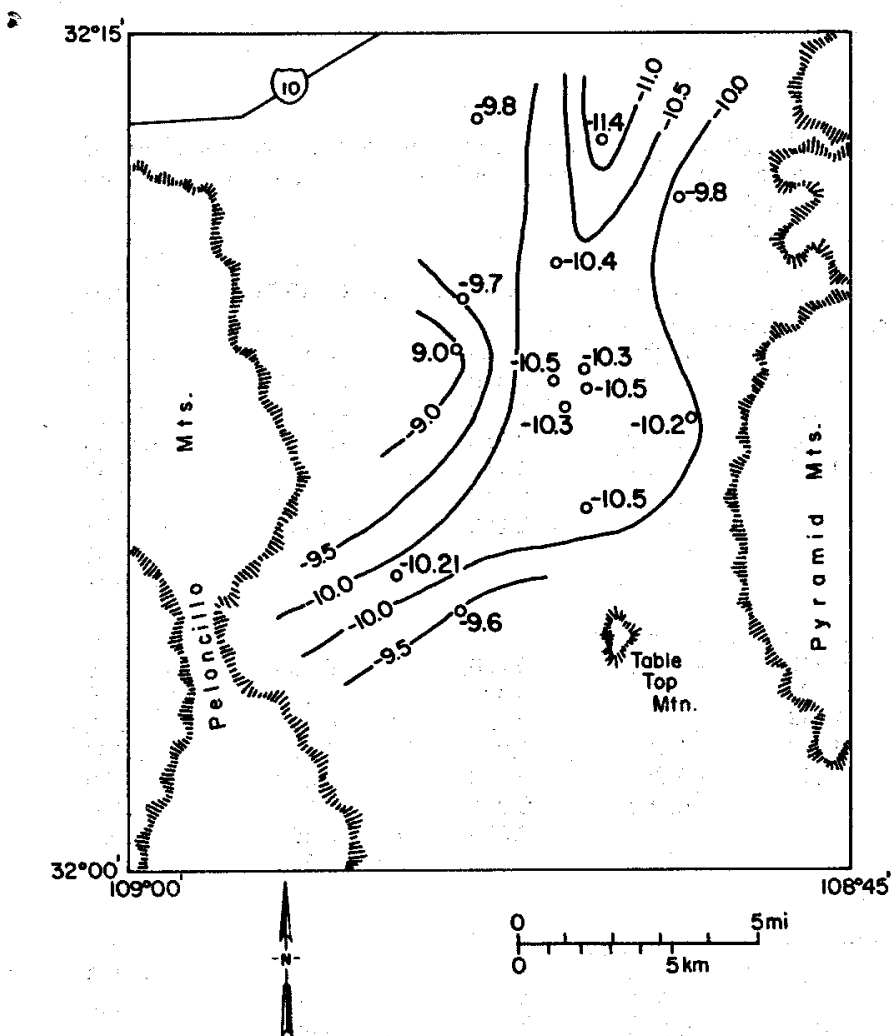

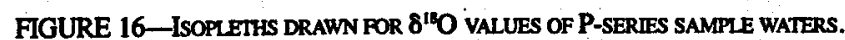

\section{Estimates of reservoir temperatures from geothermometry}

Reservoir temperatures.were estimated with the silica $\left(\mathrm{SiO}_{2}\right)$ geothermometer of Fournier and Rowe (1966), modified by more recent silica-solubility data of Walther and Helgeson (1977), and with alkali geothermometers (Fournier and Truesdell, 1973; Fournier and Potter, 1979). A comparison of the temperatures calculated by various methods using the computer program GEOTHM is given in table 3. The last column lists a "Best-Estimate" reservoir temperature, a subjective value based on comparison of the values computed by the alkali geothermometer and silica geothermometers based on the solubility of either alpha quartz or chalcedony. Best-Estimate temperatures from the samples in the lower Animas Valley in the vicinity of the KGRA are plotted and contoured in fig. 17.

In fig. 17 the isopleths define a recognizable hot spot around the hot wells, from which the chemical temperatures indicate a northerly thermal dispersion similar to that shown by temperature and temperature gradients (Kintzinger, 1956).

\section{Water-mineral interactions}

To help evaluate water-mineral interactions, multiple linear-regression and correlation-matrix calculations were performed on selected physicochemical data from the P- and LD-suites (table 4). Speculation on the physical significance of the observed correlations provides some insight into possible interpretations of the water chemistry.

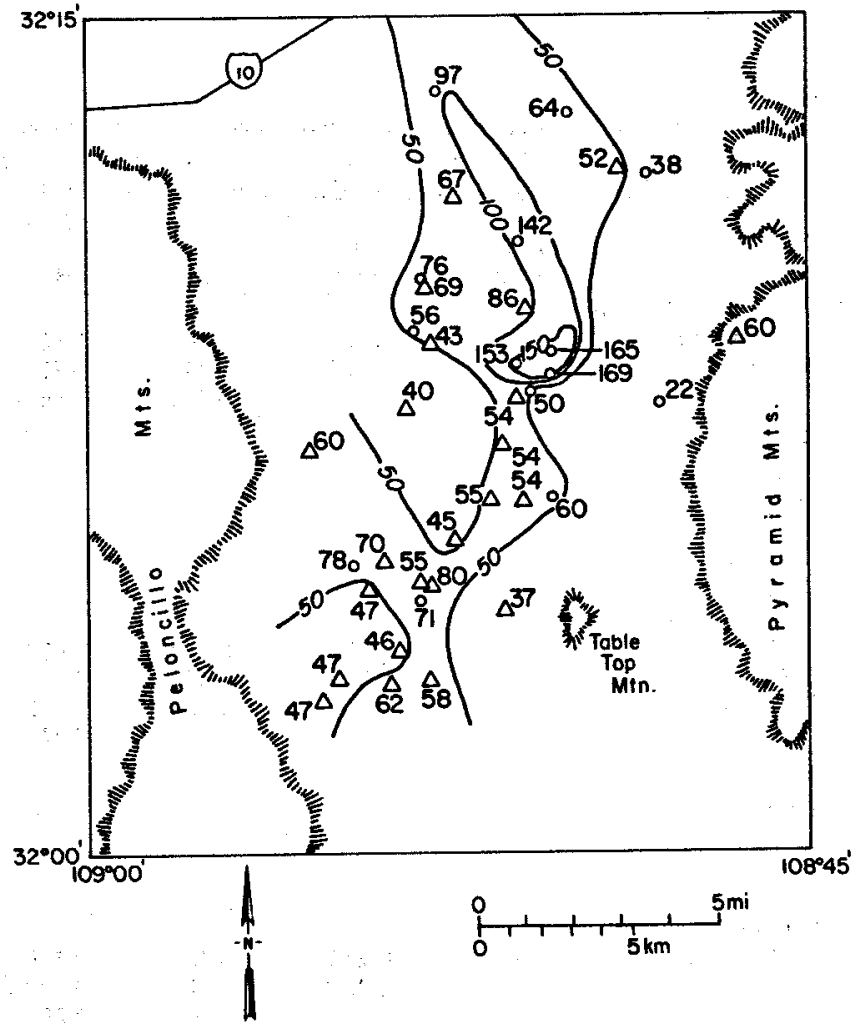

FIGURE 17-ISOPLETHS DRAWN FOR BEST ESTMMATE SHALLOW RESERVOIR TEMPERATURES OF P-SERIES ( $O$ ) AND AN-SERIES ( $\Delta$ ) WATERS; values are calculated from water chemistry and listed in table 5 .

SOURCES OF CHLORINE AND BORON-Chlorine and boron were selected as conservative or nonreactive elements, the concentrations of which are indicative of sources of components and fluids, mixing processes, and dissolution of evaporite minerals (Fournier and Truesdell, 1974; Mariner and Willey, 1976). Boron concentration correlates strongly with the calculated alkali temperatures and with the silica temperatures in P-series waters, suggesting that boron is derived primarily from the deep, high-temperature water component in the sample (table 4). The experimental results of Ellis and Mahon (1964) predict a strong correlation between temperature and chloride concentration in hydrothermal systems. The relatively poor correlation between temperature and chloride concentration in the Lightning Dock waters is probably caused by addition of chloride to the samples from the dissolution of evaporites in the playa sediments. This hypothesis is corroborated by the very strong correlation between $\mathrm{Cl}^{-}$and $\mathrm{SO}_{4}{ }^{2-}$ concentrations.

CARBONATES-Regression of the atom ratios of chlorine and boron with other components of the $\mathrm{P}$ series waters suggests further relations (table 4). The strong positive correlations of temperature with $\mathrm{B} / \mathrm{Ca}$, $\mathrm{B} / \mathrm{Mg}, \mathrm{Cl} / \mathrm{Ca}$, and $\mathrm{Cl} / \mathrm{Mg}$ may result from loss of carbon dioxide and precipitation of calcium- and magnesium-carbonate phases. The increase in the $\mathrm{Ca} / \mathrm{Mg}$ ratio with temperature suggests that magnesian calcite may be the carbonate phase that is precipitating; the $\mathrm{Ca} / \mathrm{Mg}$ ratio is too high for dolomite to be the stable carbonate.

CHLORITES AND SMECTITE (MONTMORILLONITE) CLAYS-Carbonates probably do not account for the 
TABLE 4-MULTIPLE-LINEAR-REGRESSION CORRELATION COEFFICIENTS FOR a) chemical analyses and calculated chemical geothermometers of ground waters from Animas Valley; and b) chemical geothermometers and ratios of "conservative" to "active" components in P-series ground waters from Animas Valley. Correlation coefficients greater than .5 are believed to be significant.

\begin{tabular}{|c|c|c|c|c|c|c|c|c|c|}
\hline & $\begin{array}{l}\mathrm{T}^{\circ} \mathrm{C} \\
\text { alkall }\end{array}$ & $\begin{array}{l}\mathrm{T}^{\circ} \mathrm{C} \\
\text { sillica }\end{array}$ & $\mathbf{C l}$ & B & CUB & $\mathrm{HCO}_{5}^{-}$ & $\mathrm{SO}_{4}^{-}$ & $\mathrm{HCO}_{3}-1 \mathrm{TO}_{4}=$ & $\begin{array}{c}\delta^{120} \% \infty \\
\text { (SMOW) }\end{array}$ \\
\hline $\begin{array}{l}\text { P-series and LD-series } \\
\mathrm{T}^{\circ} \mathrm{C} \text { measured } \\
\mathrm{T}^{\circ} \text { alkall } \\
\mathrm{T}^{\circ} \text { silica } \\
\mathrm{Cl} \\
\mathrm{B} \\
\mathrm{Cl} / \mathrm{B} \\
\mathrm{HCO} \\
\mathrm{SO}_{3} \\
\mathrm{HCO}_{3} / \mathrm{SO}_{4}\end{array}$ & 0.741 & $\begin{array}{l}0.736 \\
0.703\end{array}$ & $\begin{array}{l}0.400 \\
0.448 \\
0.406\end{array}$ & $\begin{array}{l}0.481 \\
0.770 \\
0.466 \\
0.585\end{array}$ & $\begin{array}{c}\text { Multiple co } \\
0.054 \\
-0.037 \\
0.035 \\
0.686 \\
0.016\end{array}$ & $\begin{array}{c}\text { ation }=0 . \\
-0.210 \\
0.140 \\
-0.101 \\
0.279 \\
0.557 \\
0.218\end{array}$ & $\begin{array}{l}0.394 \\
0.450 \\
0.542 \\
0.855 \\
0.457 \\
0.611 \\
0.215\end{array}$ & $\begin{array}{l}-0.171 \\
-0.278 \\
-0.081 \\
-0.353 \\
-0.247 \\
-0.345 \\
-0.113 \\
-0.400\end{array}$ & $\begin{array}{l}-0.294 \\
-0.511 \\
-0.203 \\
-0.488 \\
-0.703 \\
-0.227 \\
-0.558 \\
-0.460 \\
-0.198\end{array}$ \\
\hline $\begin{array}{l}\text { P-serles (14 samples) } \\
\mathrm{T}^{\circ} \mathrm{C} \text { measured } \\
\mathrm{T}^{\circ} \mathrm{C} \text { alkali } \\
\mathrm{T}^{\circ} \mathrm{C} \text { silica } \\
\mathrm{Cl} \\
\mathrm{B} \\
\mathrm{Cl} / \mathrm{B} \\
\mathrm{HCO}, \\
\mathrm{SO}_{4} \\
\mathrm{HCO}_{3} / \mathrm{SO} .\end{array}$ & 0.844 & $\begin{array}{l}0.728 \\
0.926\end{array}$ & $\begin{array}{l}0.312 \\
0.445 \\
0.332\end{array}$ & $\begin{array}{l}0.655 \\
0.871 \\
0.806 \\
0.679\end{array}$ & $\begin{array}{c}\text { Multiple co } \\
-0.245 \\
-0.305 \\
-0.344 \\
0.473 \\
-0.218\end{array}$ & $\begin{array}{c}\text { ation }=0.7 \\
-0.849 \\
-0.305 \\
-0.388 \\
-0.107 \\
-0.248 \\
0.098\end{array}$ & $\begin{array}{l}0.220 \\
0.484 \\
0.423 \\
0.911 \\
0.703 \\
0.271 \\
0.065\end{array}$ & $\begin{array}{r}-0.399 \\
-0.523 \\
-0.514 \\
-0.585 \\
-0.593 \\
-0.095 \\
0.155 \\
-0.695\end{array}$ & $\begin{array}{r}-0.278 \\
-0.408 \\
-0.382 \\
-0.699 \\
-0.700 \\
-0.118 \\
0.007 \\
-0.661 \\
-0.289\end{array}$ \\
\hline $\begin{array}{l}\text { LD-series (13 samples) } \\
\mathrm{T}^{\circ} \mathrm{C} \text { measured } \\
\mathrm{T}^{\circ} \mathrm{C} \text { alkali } \\
\mathrm{T}^{\circ} \mathrm{C} \text { silica } \\
\mathrm{Cl} \\
\mathrm{B} \\
\mathrm{Cl} / \mathrm{B} \\
\mathrm{HCO}, \\
\mathrm{SO}_{4} \\
\mathrm{HCO} / \mathrm{SO}_{4}\end{array}$ & 0.625 & $\begin{array}{l}-0.216 \\
-0.296\end{array}$ & $\begin{array}{r}0.427 \\
0.375 \\
-0.060\end{array}$ & $\begin{array}{r}0.618 \\
0.702 \\
-0.296 \\
0.620\end{array}$ & $\begin{array}{c}\text { Multiple co } \\
0.285 \\
0.169 \\
0.014 \\
0.951 \\
0.359\end{array}$ & $\begin{array}{c}\text { ation }=0 . \\
0.675 \\
0.588 \\
-0.063 \\
0.586 \\
0.939 \\
0.339\end{array}$ & $\begin{array}{r}0.664 \\
0.711 \\
-0.247 \\
0.822 \\
0.782 \\
0.661 \\
0.698\end{array}$ & $\begin{array}{r}-0.136 \\
-0.391 \\
0.622 \\
-0.387 \\
-0.387 \\
-0.308 \\
-0.127 \\
-0.596\end{array}$ & $\begin{array}{l}-0.379 \\
-0.662 \\
-0.397 \\
-0.284 \\
-0.729 \\
-0.091 \\
-0.669 \\
-0.528 \\
-0.182\end{array}$ \\
\hline
\end{tabular}

Atom ratio

\begin{tabular}{|c|c|c|c|c|c|c|c|c|c|c|}
\hline & $\mathrm{Cl} / \mathrm{Ca}$ & CuMg & CUK & CUNa & CUF & CusO. & $\mathrm{CU}_{\mathrm{HCO}}$ & $\mathrm{Ca} / \mathrm{Mg}$ & $\frac{\mathrm{Na}}{\mathrm{Cl}+\mathrm{HCO}_{2}}$ & $\delta^{11} 0 \%$ \\
\hline $\begin{array}{l}\mathrm{T}^{\circ} \mathrm{C} \text { measured } \\
\mathrm{T}^{\circ} \mathrm{C} \text { alkali } \\
\mathrm{T}^{\circ} \mathrm{C} \text { silica } \\
\mathrm{Cl} / \mathrm{Ca} \\
\mathrm{Cl} / \mathrm{Mg} \\
\mathrm{Cl} / \mathrm{K} \\
\mathrm{Cl} / \mathrm{Na} \\
\mathrm{Cl} / \mathrm{F} \\
\mathrm{Cl} / \mathrm{SO}, \\
\mathrm{Cl} / \mathrm{HCO}, \\
\mathrm{Ca} / \mathrm{Mg}\end{array}$ & $\begin{array}{l}0.827 \\
0.848 \\
0.757\end{array}$ & $\begin{array}{l}0.838 \\
0.784 \\
0.740 \\
0.908\end{array}$ & $\begin{array}{l}-0.483 \\
-0.520 \\
-0.566 \\
-0.196 \\
-0.434\end{array}$ & $\begin{array}{r}-0.171 \\
-0.155 \\
-0.242 \\
0.005 \\
-0.144 \\
0.667\end{array}$ & $\begin{array}{r}-0.314 \\
-0.396 \\
-0.465 \\
-0.298 \\
-0.354 \\
0.510 \\
0.691\end{array}$ & $\begin{array}{l}0.324 \\
0.230 \\
0.083 \\
0.428 \\
0.309 \\
0.277 \\
0.518 \\
0.697\end{array}$ & $\begin{array}{r}0.755 \\
0.725 \\
0.586 \\
0.708 \\
0.562 \\
-0.010 \\
0.425 \\
0.046 \\
0.499\end{array}$ & $\begin{array}{r}0.776 \\
0.781 \\
0.819 \\
0.810 \\
0.955 \\
-0.583 \\
-0.281 \\
-0.480 \\
0.110 \\
0.437\end{array}$ & $\begin{array}{r}0.901 \\
0.920 \\
0.821 \\
0.780 \\
0.677 \\
-0.410 \\
-0.145 \\
-0.338 \\
0.250 \\
0.812 \\
0.639\end{array}$ & $\begin{array}{l}-0.278 \\
-0.414 \\
-0.361 \\
-0.507 \\
-0.251 \\
-0.335 \\
-0.350 \\
-0.129 \\
-0.518 \\
-0.580 \\
-0.125\end{array}$ \\
\hline $\mathrm{Na}$ & & & & & & & & & & \\
\hline$\overline{\mathrm{Cl}+\mathrm{HCO}_{3}}$ & & & & & & & & & & -0.451 \\
\hline
\end{tabular}

Multiple correlation $=0.898$

\begin{tabular}{|c|c|c|c|c|c|c|c|c|c|c|}
\hline & B/Ca & $\mathrm{B} / \mathrm{Mg}$ & B/K & $\mathrm{B} / \mathrm{Na}$ & BIF & B/SO. & B/HCO, & $\mathrm{Ca} / \mathrm{Mg}$ & $\frac{\mathrm{Na}}{\mathrm{B}+\mathrm{HCO}_{2}}$ & $\delta^{11} 0 \%$ \\
\hline $\begin{array}{l}T^{\circ} \mathrm{C} \text { measured } \\
\mathrm{T}^{\circ} \mathrm{C} \text { alkali } \\
\mathrm{T}^{\circ} \mathrm{C} \text { sillica } \\
\mathrm{B} / \mathrm{Ca} \\
\mathrm{B} / \mathrm{Mg} \\
\mathrm{B} / \mathrm{K} \\
\mathrm{B} / \mathrm{Na} \\
\mathrm{B} / \mathrm{F} \\
\mathrm{B} / \mathrm{SO}_{4} \\
\mathrm{~B} / \mathrm{HCO} \\
\mathrm{Ca} / \mathrm{Mg}\end{array}$ & $\begin{array}{l}0.809 \\
0.865 \\
0.807\end{array}$ & $\begin{array}{l}0.824 \\
0.791 \\
0.753 \\
0.941\end{array}$ & $\begin{array}{l}-0.409 \\
-0.400 \\
-0.424 \\
-0.149 \\
-0.319\end{array}$ & $\begin{array}{l}0.286 \\
0.491 \\
0.400 \\
0.636 \\
0.513 \\
0.116\end{array}$ & $\begin{array}{l}-0.239 \\
-0.317 \\
-0.456 \\
-0.252 \\
-0.280 \\
-0.259 \\
-0.109\end{array}$ & $\begin{array}{r}0.659 \\
0.641 \\
0.538 \\
0.793 \\
0.735 \\
-0.088 \\
0.638 \\
0.285\end{array}$ & $\begin{array}{r}0.944 \\
0.924 \\
0.823 \\
0.880 \\
0.826 \\
-0.297 \\
0.484 \\
-0.292 \\
0.694\end{array}$ & $\begin{array}{r}0.777 \\
0.782 \\
0.818 \\
0.875 \\
0.958 \\
-0.441 \\
0.364 \\
-0.410 \\
0.597 \\
0.752\end{array}$ & $\begin{array}{r}0.910 \\
0.484 \\
0.716 \\
0.663 \\
0.616 \\
-0.351 \\
0.225 \\
-0.077 \\
0.617 \\
0.907 \\
0.559\end{array}$ & $\begin{array}{l}-0.281 \\
-0.408 \\
-0.383 \\
-0.360 \\
-0.241 \\
-0.287 \\
-0.309 \\
-0.098 \\
-0.365 \\
-0.483 \\
-0.125\end{array}$ \\
\hline $\mathrm{Na}$ & & & & & & & & & & -0.478 \\
\hline $\mathrm{B}+\mathrm{HCO}_{3}$ & & \multicolumn{9}{|c|}{ Multiple correlation $=0.990$} \\
\hline
\end{tabular}


- removal of most of the $\mathbf{M g}^{2+}$ from solution. By considering relationships between $\mathrm{Ca}^{2+}, \mathrm{Mg}^{2+}, \mathrm{HCO}_{3}{ }^{-}$, and $\mathrm{SO}_{4}{ }^{2-}$ and total dissolved solids (TDS) in solution, the $\mathrm{Mg}^{2+}$ and $\mathrm{HCO}_{3}{ }^{-}$concentrations can be shown to be controlled primarily by the formation of magnesium smectite (Logsdon, 1981). This conclusion is supported by calculation of saturation indices and mineralstability diagrams, by the recognition of smectites and chlorites in alteration assemblages at numerous studied geothermal areas (Browne, 1978), and by the experimental results of seawater-basalt interaction, in which magnesium is removed from seawater quantitatively by the formation of magnesium montmorillonite (Mottl and Holland, 1978). Calcium concentrations of the solutions also may be affected by incorporation of $\mathrm{Ca}^{2+}$ into silicates, particularly zeolites and smectites (Logsdon, 1981).

SOURCE OF SULFATE-The increase in $\mathrm{SO}_{4}{ }^{2-}$ with TDS already has been ascribed to dissolution of evaporites in the playa sediments. The $\mathrm{Ca}^{2+}$ concentration is much lower than that needed to balance the sulfate $\mathrm{SO}_{4}{ }^{2-}$, but the discrepancy can be met by considering the $\mathrm{Ca} /\left(\mathrm{SO}_{4}{ }^{2-}+\mathrm{HCO}_{3}{ }^{-}\right)$molar ratio. In Animas Valley water samples, this ratio is less than 1 . In general, if the ratio is less than 1, precipitation of $\mathrm{CaCO}_{3}$ or $\mathrm{CaSO}_{4}$ will deplete a solution in $\mathrm{Ca}^{2}+$ but not in $\mathrm{HCO}_{3}{ }^{-}$or $\mathrm{SO}_{4}{ }^{2-}$. The potential charge imbalance through loss of $\mathrm{Ca}^{2+}$ without equivalent loss of $\mathrm{SO}_{4}{ }^{2-}$ is offset by the removal from solution of a larger molar proportion of anions than cations and by increased leaching of singly charged cations, especially $\mathrm{Na}^{+}$. Gypsum and anhydrite are the only poorly soluble sulfate minerals that can control the concentration of $\mathrm{SO}_{4}{ }^{2-}$ in natural solutions. Since $\mathrm{CaSO}_{4}$ is being dissolved, not precipitated, the $\mathrm{SO}_{4}{ }^{2-}$ concentration in the solution increases in proportion to the $\mathrm{Ca}^{2+}$ and $\mathrm{HCO}_{3}{ }^{-}$concentrations.

Alternatively, $\mathrm{SO}_{4}{ }^{2-}$ could be added to the waters by oxidation of deep $\mathrm{H}_{2} \mathrm{~S}$, a process commonly observed in vapor-dominated geothermal systems (White, 1957). However, no evidence exists for the modern geothermal system having acid sulfate water affinities. None of the samples is saturated with respect to alunite, and the $\mathrm{pH}$ of the solutions seems to have been firmly buffered at values in the neutral to slightly alkaline range. While large-scale oxidation of $\mathrm{H}_{2} \mathrm{~S}$ seems unlikely and is not required to explain the chemical data, its possible influence could be checked by a careful study of the sulfurisotope systematics.

FELDSPARS AND SILICA-While most of the $\mathrm{Na}^{+}$and $\mathrm{Ca}^{2}+$ in the water samples appears to have been derived from the dissolution of evaporites, the agreement between reservoir temperatures calculated by the $\mathrm{Na}-\mathrm{K}$, $\mathrm{Na}-\mathrm{K}-\mathrm{Ca}$, and $\mathrm{SiO}_{2}$ geothermometers for the hot wells (samples P2, P3, P4, and P24) suggests that $\mathrm{Na}^{+}, \mathrm{K}^{+}$, and $\mathrm{Ca}^{2+}$ concentrations in the deepest and hottest parts of the reservoir are controlled by equilibrium cation-exchange reactions between feldspars and solution. The $\mathrm{SiO}_{2}$ concentration of fluids is controlled by the solubility of a silica phase. Alpha-quartz solubility gives the best agreement of silica and alkali temperatures for temperatures greater than $100^{\circ} \mathrm{C}\left(212^{\circ} \mathrm{F}\right)$; below $100^{\circ} \mathrm{C}$, the agreement is best for chalcedony solubility. (Landis and Logsdon, 1980). This interpretation of the solubility control of silica is consistent with the detailed work on low-temperature systems in Iceland (Arnorsson, 1975) and with the observations at numerous sites in western North America (R. O. Fournier, U.S. Geological Survey, personal communication, 1979).

FLUORITE-Fluoride ion in solution is controlled by the solubility of fluorite $\left(\mathrm{CaF}_{2}\right)$. Green fluorite, similar to samples from the Doubtful (Animas) mine along the eastern margin of the Animas Valley, can be seen in microscopic examination of drill chips from the Cockrell \#1 well. The association of the fluorite deposits and high-F- $\mathrm{F}^{-}$ground water is probably the strongest piece of evidence linking the modern geothermal system to the older, more extensive hydrothermal activity in the valley.

MINERALS IN EQUILIBRIUM WITH ANIMAS VALLEY GROUND WATERS-If one assumes that the Animas Valley waters are at chemical equilibrium, applying numerical and graphical techniques to the chemistry of the waters to calculate mineral phases with which the solutions could be in equilibrium is possible. The saturation index (SI) for a mineral may be defined as SI $=\mathrm{log}$ (IAP/K), where IAP is the ion-activity product of the appropriate species in solution and $K$ is the thermodynamic equilibrium constant of the mineral. At chemical equilibrium, SI $=0$. Therefore, $\mathrm{SI}$ greater than $0 \mathrm{im}$ plies supersaturation; SI less than 0 implies undersaturation. The computer program WATEQF was used to compute saturation indices for mineral phases which might be controlling the chemical composition of the lower Animas Valley waters. Table 5 lists the calculated mineral phases that could be in chemical equilibrium with the ground waters of the Animas Valley.

\section{Structural control and flow of thermal waters}

Truesdell (1976) has shown that a spatial analysis of the chemistry of geothermal waters can produce useful information on subsurface structures and the direction of flow in a geothermal system. $\mathrm{B} / \mathrm{Ca}, \mathrm{B} / \mathrm{Na}$, and $\mathrm{SO}_{4} / \mathrm{F}$ ratios can be used to distinguish the effects of tempera-

TABLE 5-MINERALS CALCULATED BY WATEQF TO BE IN CHEMICAL EQUTLIBRIUM WITH GROUND WATERS OF LOWER ANIMAS VALLEY. A saturation index greater than zero implies supersaturation; a saturation index less than zero implies undersaturation.

\begin{tabular}{lrr}
\hline \hline & \multicolumn{2}{c}{ Saturation index } \\
\cline { 2 - 3 } & \multicolumn{1}{c}{ Minimum } & Maximum \\
\hline Quartz & -1.73 & +1.19 \\
Chalcedony & -2.22 & +0.68 \\
Kaolinite & -1.46 & +7.05 \\
Montmorillonite & -5.24 & +10.69 \\
Illite & -4.42 & +7.56 \\
Chlorite & -1.72 & +7.90 \\
Calcite & -0.07 & +0.58 \\
Siderite & -27.39 & +0.62 \\
Analcime & -10.57 & +0.17 \\
Wairakite & -16.15 & +3.29 \\
Laumontite & -5.71 & +7.44 \\
Prehnite & -6.27 & +3.42 \\
Adularia & -577 & +3.76 \\
Albite & -9.11 & +2.70 \\
Hematite & +0.86 & +25.44 \\
Pyrite & +5.47 & +16.34 \\
Fluorite & -1.54 & +0.76 \\
\hline
\end{tabular}


ture, mixing, and dilution in natural waters (Logsdon, 1981). B/Ca (fig. 18), B/Na (fig. 19), and SO $/ \mathrm{F}$ (fig. 20) molar ratios are plotted and contoured in the same manner as $\delta^{18} 0$ values in fig. 16 and temperature values in fig. 17. Figs. 16-20 illustrate common features: 1) mixing and dilution of deep-reservoir water by shallow aquifer water, 2) dispersion of deep-reservoir components by the shallow flow regime to the north of the hot wells, and 3) leakage of deep-reservoir components into the shallow aquifer in an area southwest of the hot wells. The persistence of the linear trend in the isopleths constructed on the basis of major and minor chemical components and isotopic data is strong evidence that the trend is real and related to subsurface structure. Anomalous temperatures can identify geothermal reservoir fluid only where it reaches the surface as a major component of the water mixture sampled in a well. Even where waters are not unusually hot, a minor geothermal component can be detected by its chemical signature. Southwest of the hot wells, geothermal reservoir fluid seems to be leaking into the near-surface aquifers. High temperatures are indicated chemically, but thermal evidence is absent because of the extreme dilution of the deep reservoir water by shallow ground water.

\section{Mixing model}

The chemistry of the waters from the hot wells meets all the standard tests for mixed water in a geothermal system: variations in temperature, variations in content of relatively nonreactive components, variations in the ratios of nonreactive to reactive components, and significant deviation of chemically calculated temperatures

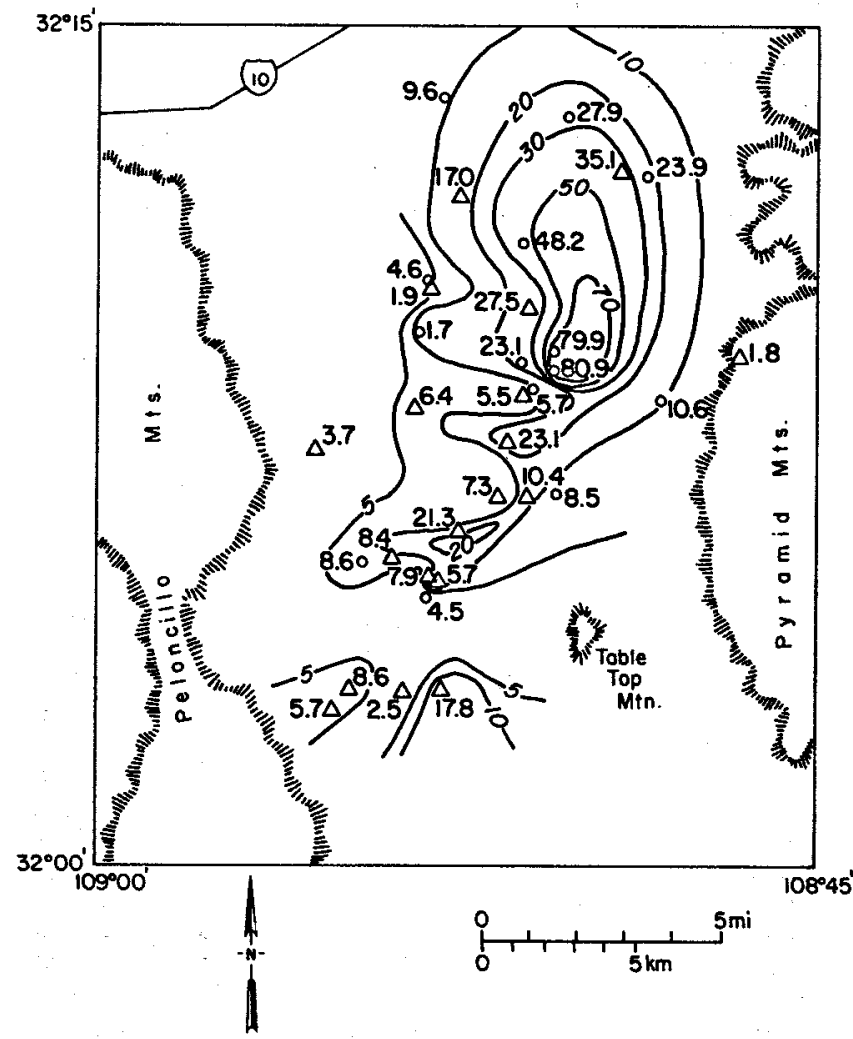

FIGURE 18-ISOPLETHS DRAWN FOR BORON/CALCIUM MOLAR RATIOS (X 103) IN P-SERIES $(O)$ AND AN-SERIES $(\Delta)$ WATERS.

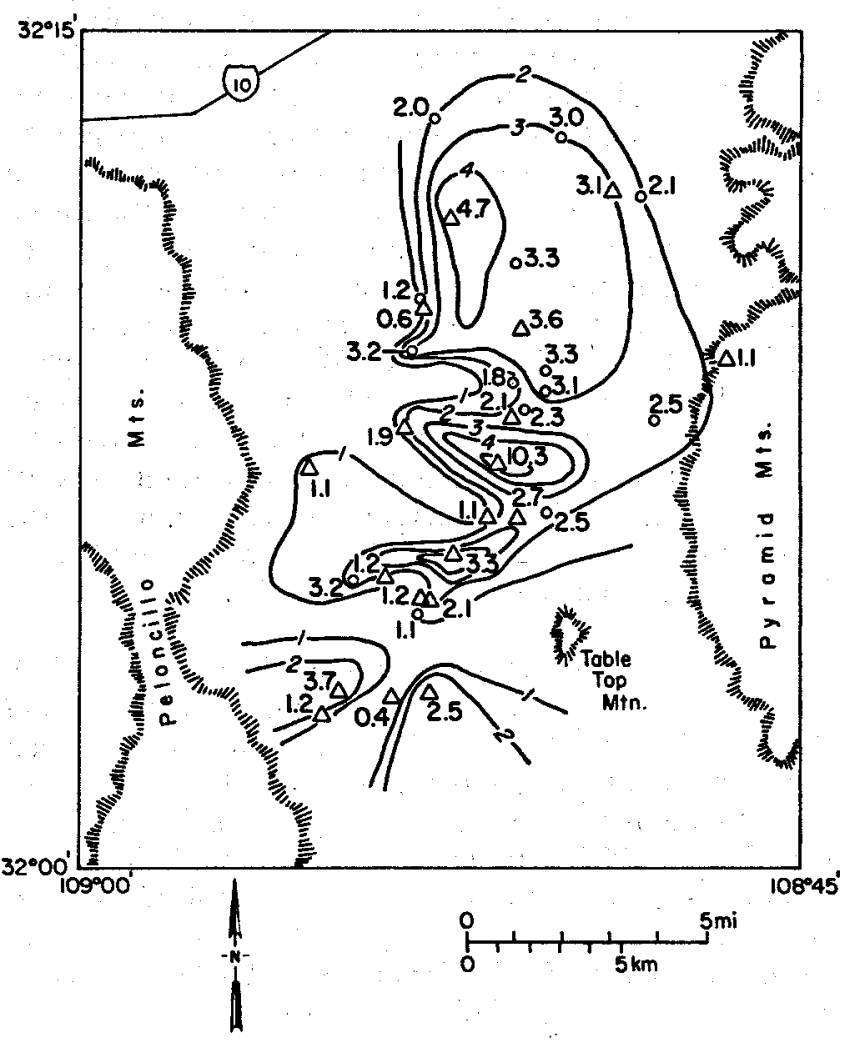

FIGURE 19-ISOPLETHS DRAWN FOR BORON/SODIUM MOLAR RATTOS (X 103) IN P-SERIES ( $(O)$ AND AN-SERIES $(\Delta)$ WATERS.

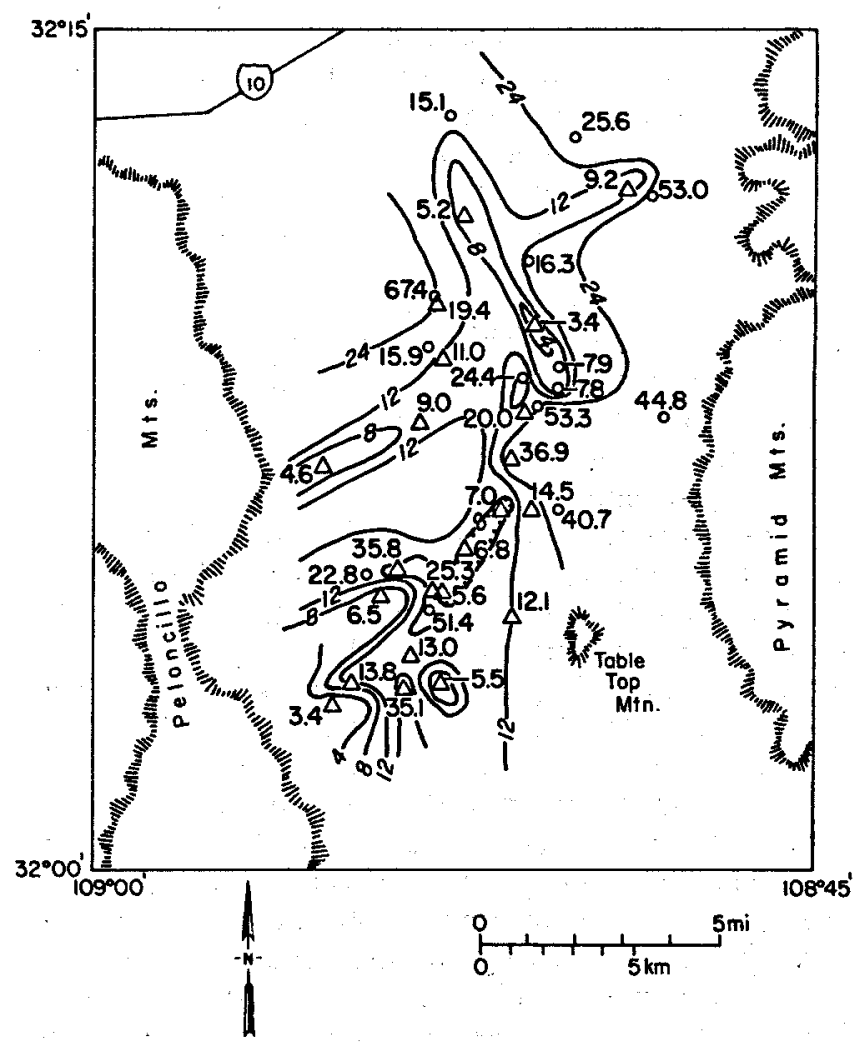

FIGURE 20-ISOPLETHS DRAWN FOR SULFATE/FLUORIDE MOLAR RATIOS IN PSERIES $(O)$ AND AN-SERIES $(\Delta)$ WATERS. 
$+$

- from measured temperatures (Fournier and Truesdell, 1974; Fournier and others, 1974).

To determine the degree of mixing and to characterize the water chemistry of the high-temperature geothermal reservoir, a mixing model described by Truesdell and Fournier (1977) was applied. The model is limited by three basic assumptions: 1) the concentration of silica does not change by dissolution or precipitation during or after mixing, 2) no heat is lost from the total fluid system by conduction (that is, adiabatic cooling occurs at constant enthalpy), and 3) a steam phase, if formed, does not separate (Fournier and others, 1974). Using these assumptions, the concentration of dissolved silica and all temperature changes are controlled solely by mixing.

Fig. 21, after Truesdell and Fournier (1977), illustrates the application of the mixing model. The waters of the hot wells, P2, P3, and P4, are assumed to represent a two-component mixture consisting of a cold, shallow-aquifer component, represented by sample $\mathbf{P 1}$, and a high-temperature geothermal-reservoir component. P1 was chosen as a geographically close, lowtemperature sample that is located up the hydrologic gradient from the hot wells and that can be considered representative of the dilute, shallow ground-water component. The silica concentration for each sample is given in milligrams per kilogram (ppm). Because the system is assumed to be isenthalpic, silica solubility is plotted as a function of enthalpy of liquid water, rather than of temperature. When the enthalpy of liquid water is calculated in International Table calories per gram, the numerical value of the enthalpy is nearly identical to the temperature in degrees Celsius up to $250^{\circ} \mathrm{C}\left(482^{\circ} \mathrm{F}\right)$.

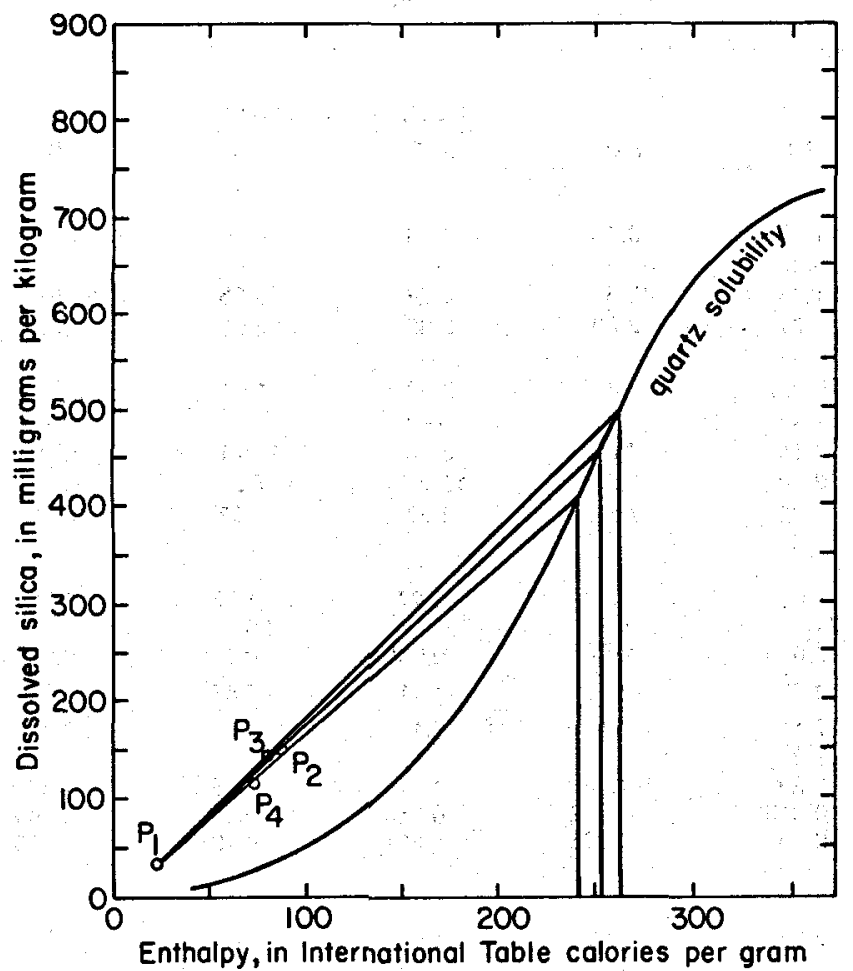

FIGURE 21-PLOTOF DISSOLVED SUICA VERSUS ENTHALPY USED TO ESTIMATE TEMPERATURE AND FRACTION OF HOT-WATER COMPONENT IN A MIXED WATER. Samples P2, P3, and P4 are mixed waters from hot wells; P1 is a geographically close, low-temperature water (after Truesdell and Fournier, 1977).
Above $250^{\circ} \mathrm{C}\left(482^{\circ} \mathrm{F}\right)$, the Steam Tables can be used to convert rapidly between enthalpy and temperature. Projecting a line from $P 1$ through a mixed-water point to the quartz-solubility curve gives the silica concentration and the enthalpy (temperature) of the high-temperature component, called $R$, in the mixture. Further, the lever rule can be applied to determine the percentage of P1 and $R$ in the mixture.

The graphical mixing technique yields a deepreservoir component of approximately $25 \%$ in the waters of the hot wells. Enthalpy is about $250 \mathrm{cal} / \mathrm{gram}$; therefore, temperature is approximately $250^{\circ} \mathrm{C}\left(482^{\circ} \mathrm{F}\right)$. A numerical mass-balance calculation on the mixing trend of the isotopic data of fig. 15, using a modern meteoric water of $\delta^{18} 0=-9.6$ (sample P1) permil, a deep water of $\delta^{18} 0=-13.4$, and a mixed-water value of $\delta^{18} 0=-10.5$ permil (sample $P 2$ ),

$$
-10.5 \%=x(-13.4 \%)+(1-x)(9.6 \%) \text {, }
$$

yields a deep-reservoir contribution of $24 \%$. The close agreement between the two independent computations strongly supports the validity of the mixing model.

Table 6 presents mixing percentages, deep-reservoir temperatures, and calculated reservoir chemistries based on the application of the mixing model. The mixed waters of the hot wells contain approximately $25 \%$ of a deep geothermal reservoir-water component that has a temperature of approximately $250^{\circ} \mathrm{C}\left(482^{\circ} \mathrm{F}\right)$. The reservoir-fluid chemistry is calculated using the appropriate hot-water fraction for each well and the analyzed chemistry of cold-well P1 and the hot well of interest. From the calculated deep-reservoir chemistry, temperature is determined by the $\mathrm{Na}-\mathrm{K}-\mathrm{Ca}$ geothermometer. For R2 and R3 the alkali temperature agrees very closely with the independently determined silica-enthalpy mixing-model temperature. Although for R4 the agreement is not satisfactory, the post-mixing addition of dissolved solids can be calculated and the corrected reservoir (R4 $4^{1}$ chemistry yields an alkali temperature in good agreement with the mixing-model temperature (Logsdon, 1981).

The negative values of $\mathrm{Mg}^{2+}$ and $\mathrm{HCO}_{3}{ }^{-}$in the mass balance of the reservoir composition require that the concentrations of $\mathrm{Mg}^{2+}$ and $\mathrm{HCO}_{3}{ }^{-}$are too low in the P-series mixed waters. The most likely explanation is that $\mathrm{Mg}^{2+}$ and $\mathrm{HCO}_{3}^{-}$were lost in chemical reactions that led to the formation of mineral phases after mixing. As suggested above, formation of magnesium smectite probably controlled the $\mathrm{Mg}^{2+}$ and $\mathrm{HCO}_{3}{ }^{-}$concentration in the mixed-water solutions.

\section{Geothermal reservoir Physicochemical environment}

The general features of the physicochemical environment of the deep-geothermal reservoir can be modeled by assuming chemical equilibrium in the model-reservoir waters. The physicochemical data in table 7 are used to characterize the shallow water, mixed water, and deep-reservoir water. The calculations of the water chemistry, presented in molality, have already been described. The other parameters in table 7 are described in detail in Logsdon (1981). 
TABLE 6-MIXING ESTTMATES AND CALCULATED RESERVOIR CHEMISTRY (VALUES IN PARTS PER MILLION) USING MIXING MODEL OF FOURNIER AND TRUESDELL (1974). P1 is a representative cold water; " $\mathrm{T}^{\circ} \mathrm{C}$ Reservoir" is reservoir temperature calculated from silica geothermometer (Fournier and Rowe, 1966; solubility data from Walther and Helgeson, 1977); R2Q is temperature calculated using alpha-quartz solubility for sample P2; R2C is temperature calculated using chalcedony solubility for sample $\mathrm{P} 2$, and so on; $\mathrm{X}$ is fraction of hot water in mixture. The chemistry of the reservoir fluid is then calculated from mass balance considerations (Logsdon, 1981). " $\mathrm{T}{ }^{\circ} \mathrm{C}$ Alkali" is reservoir temperature calculated from the Na-K-Ca geothermometer (Fournier and Truesdell, 1973) using the chemistry calculated for R2Q or R2C and so on. The significance of negative concentrations for $\mathrm{Mg}^{2+}$ and $\mathrm{HCO}_{3}^{-}$is discussed in Logsdon (1981).

\begin{tabular}{|c|c|c|c|c|c|c|c|c|c|c|}
\hline & $P_{1}$ & P 2 & R2O & R2C & P 3 & R3O & R3C & P 4 & R4a & R4C \\
\hline $\begin{array}{l}\mathrm{T}^{\circ} \mathrm{C} \\
\text { reservoir } \\
\mathrm{X} \\
\mathrm{T}^{\circ} \mathrm{C} \\
\text { alkali }\end{array}$ & 32 & 169 & $\begin{array}{c}250 \\
0.27 \\
246\end{array}$ & $\begin{array}{l}232 \\
0.30 \\
241\end{array}$ & 165 & $\begin{array}{l}262 \\
0.24 \\
240\end{array}$ & $\begin{array}{l}238 \\
0.27 \\
237\end{array}$ & 156 & $\begin{array}{l}241 \\
0.23 \\
211\end{array}$ & $\begin{array}{c}221 \\
0.24 \\
211\end{array}$ \\
\hline $\mathrm{Ca}^{2+}$ & 28.0 & 22.0 & 5.8 & 8.0 & 23.2 & 8.0 & 10.2 & 67.3 & 198.9 & 191.8 \\
\hline $\mathrm{Mg}^{2+}$ & 7.3 & 0.5 & -17.4 & 0.8 & -15.4 & -23.1 & -16.8 & 5.3 & -1.4 & -1.0 \\
\hline $\mathrm{Na}^{+}$ & 68.7 & 333.6 & $1,049.8$ & 951.7 & 318.6 & $1,110.0$ & 994.3 & 493.1 & $1,913.9$ & $1,837.0$ \\
\hline $\mathrm{K}$ : & 1.9 & 23.5 & 81.9 & 73.9 & 21.1 & 81.9 & 73.9 & 27.8 & 114.5 & 109.8 \\
\hline $\mathrm{HCO}_{3}-$ & 183.1 & 106.8 & -99.5 & -71.2 & 103.7 & -147.7 & -110.0 & 118.9 & -96.0 & -84.4 \\
\hline $\mathrm{Cl}^{-}$ & 20.5 & 88.3 & 271.6 & 246.5 & 87.6 & 300.1 & 269.0 & 111.3 & 415.3 & 398.8 \\
\hline $\mathrm{SO}^{2-}$ & 79.3 & 497.1 & $1,626.7$ & $1,476.0$ & 480.0 & $1,748.9$ & $1,563.4$ & 893.4 & $3,618.9$ & $3,471.4$ \\
\hline $\mathrm{SiO}_{2}$ & 31.3 & 147.5 & 461.7 & 418.6 & 143.0 & 496.7 & 445.0 & 115.6 & 397.8 & 382.6 \\
\hline B & 0.08 & 0.48 & 1.56 & 1.41 & 0.5 & 1.83 & 1.64 & 0.42 & 1.56 & 1.50 \\
\hline$F^{-}$ & 0.35 & 12.6 & 45.7 & 41.2 & 12.0 & 48.9 & 43.5 & 7.3 & 30.6 & 29.3 \\
\hline
\end{tabular}

TABLE 7-PHYSICOChEMICAL PARAMETERS FOR SHALLOW-AQUIFER WATER (P1), MIXED WATERS (P2, P3, P4), AND MODELED GEOTHERMAL RESERVOR WATERS OF THE LIGHTNING DOCK KGRA. $\bar{I}$ is ionic strength; $\mathrm{fCO}_{2}$ is thermodynamic fugacity of carbon dioxide; $\gamma_{i}$ is thermodynamic activity coefficient of the ith species; $\gamma \pm$ is mean activity coefficient for singly charged ions; $\gamma \pm \pm$ is mean activity coefficient for doubly charged ions; $a$ is thermodynamic activity of the ith species in solution.

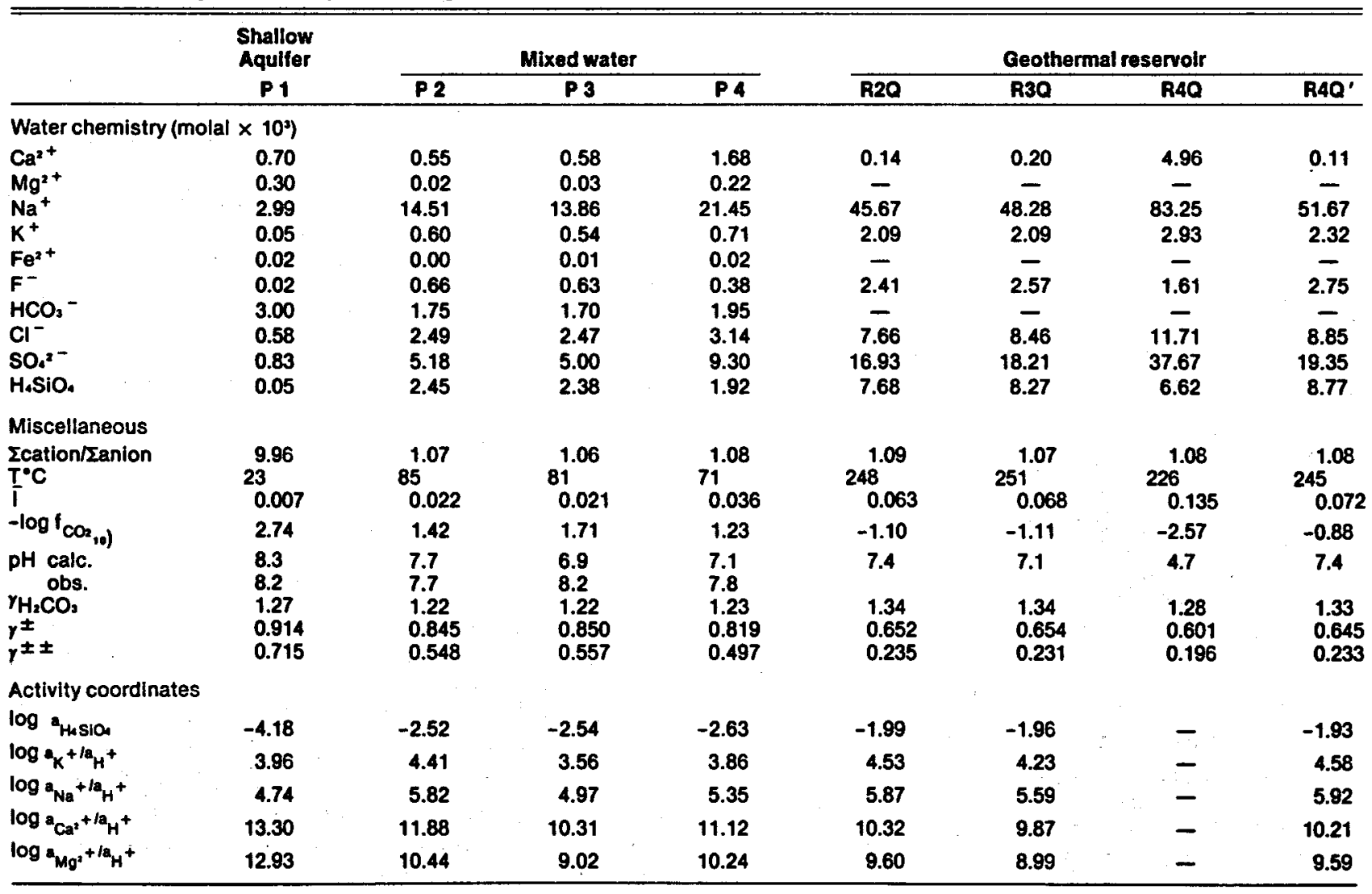




\section{Calculated alteration phases}

Using thermodynamic data, one may construct chemical-potential or activity diagrams that show the stability fields of mineral phases in terms of the ratios of activities of aqueous species. Computed activity ratios for the waters are plotted on the mineral-stability diagrams. Temperatures of $25^{\circ} \mathrm{C}, 150^{\circ} \mathrm{C}$, and $250^{\circ} \mathrm{C}$ $\left(77^{\circ} \mathrm{F}, 302^{\circ} \mathrm{F}\right.$, and $\left.482^{\circ} \mathrm{F}\right)$ were chosen to illustrate relationships at near-surface, mixed-water, and deep-reservoir conditions, respectively.

Studies of alteration assemblages are incomplete because core samples from deep holes near the hot wells are unavailable at present. The use of saturation indices or mineral-stability diagrams can only demonstrate the reasonable mineral phases that would be in chemical equilibrium with the waters at the given temperatures. The fact that a water composition indicates saturation with respect to a given mineral or plots in the stability field of a mineral neither requires the mineral to be present nor indicates the quantity that might be present. Kinetic relationships and components not treated in the calculations must also be considered. Nevertheless, the calculations lead to a consistent model that can be tested by later studies.

Fig. 22 is a plot of $\left(\log a_{K}+/ \log a_{H^{+}}\right)$and of (log $a_{\mathrm{Na}}+\log _{\mathrm{H}^{+}}+$against $\mathrm{a}_{\mathrm{H}_{4} \mathrm{SiO}_{4}}$ on which water compositions with different Best-Estimate temperatures have been plotted. A clear trend exists in the data with increasing temperature, indicating that the solutions have changed composition as a function of temperature.

The compositions of minerals with which the waters are in chemical equilibrium also depend on temperature. Figs. 23-25 are mineral-stability diagrams (Helgeson and others, 1969) on which the water compositions for the appropriate temperatures have been plotted. Fig. 23, for the system $\mathrm{HCl}-\mathrm{H}_{2} \mathrm{O}-\mathrm{Al}_{2} \mathrm{O}_{3}-\mathrm{K}_{2} \mathrm{O}-\mathrm{Na}_{2} \mathrm{O}-\mathrm{SiO}_{2}$ at $25^{\circ} \mathrm{C}\left(77^{\circ} \mathrm{F}\right)$, indicates that the shallow, cool ground waters are in equilibrium with kaolinite. Fig. 24, for the same system at $150^{\circ} \mathrm{C}$ and $250^{\circ} \mathrm{C}\left(302^{\circ} \mathrm{F}\right.$ and $\left.482^{\circ} \mathrm{F}\right)$ shows that sodium montmorillonite is the expected alteration phase in the mixed-water region, but that deep-reservoir waters would be in equilibrium with
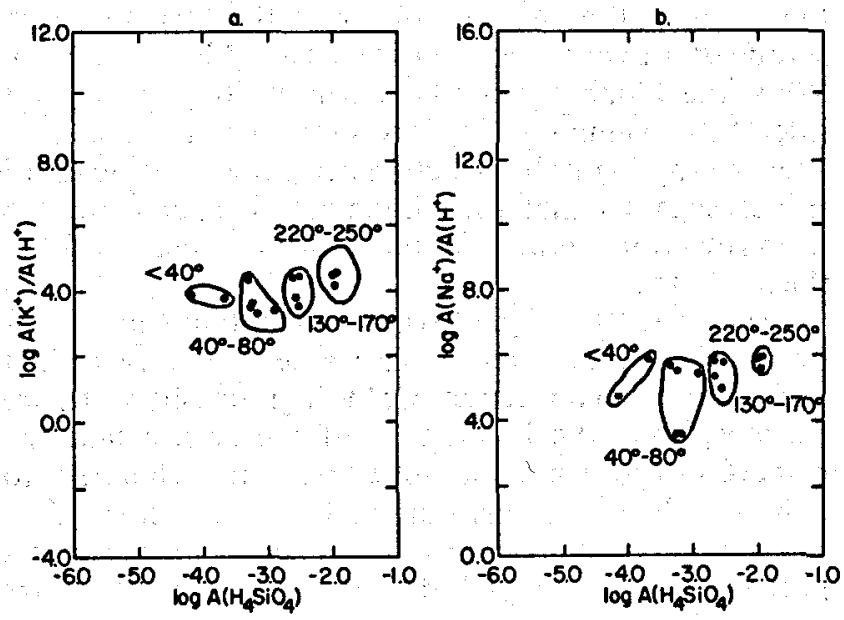

FIGURE 22-PLOTS OF (LOO $\left.A_{K}+h O G A_{N}+\right)$ AND (LOG $\left.A_{N_{A}}+/ \operatorname{LOG} A_{H}+\right)$ VERSUS LOG $\mathrm{AH}_{4} \mathrm{SIO}_{4}$ for representative water samples and for calculated geothermal reservoir waters $\mathbf{R} 2, \mathbf{R} 3$, and $\mathbf{R} 4$. Temperature groupings are based on Best-Estimate temperatures listed in table 4.

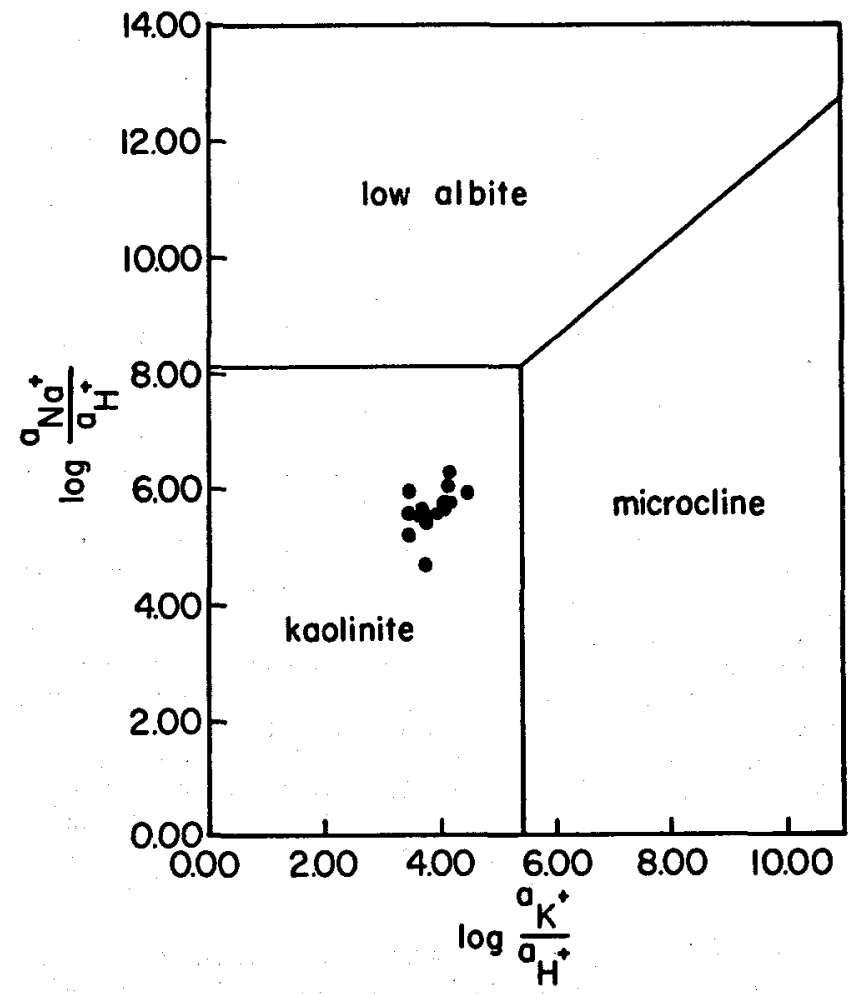

FIGURE 23 - COMPOSITION OF LOW-TEMPERATURE SAMPLE WATERS PLOTTED ON MINERAL STABITY DIAGRAM for system $\mathrm{HCl}-\mathrm{H}_{2} \mathrm{O}-\mathrm{Al}_{2} \mathrm{O}_{3}-\mathrm{K}_{2} \mathrm{O}-\mathrm{Na}_{2} \mathrm{O}$ $\mathrm{SiO}_{2}$ at $25^{\circ} \mathrm{C}\left(77^{\circ} \mathrm{F}\right)$ and $\log$ a $_{4} \mathrm{SiO}_{4}=-4.00=$ quartz saturation (phase boundaries after Helgeson and others, 1969). All P-series values except those at hot wells are plotted, but only selected An-series and LD-series values are plotted to avoid clutter.
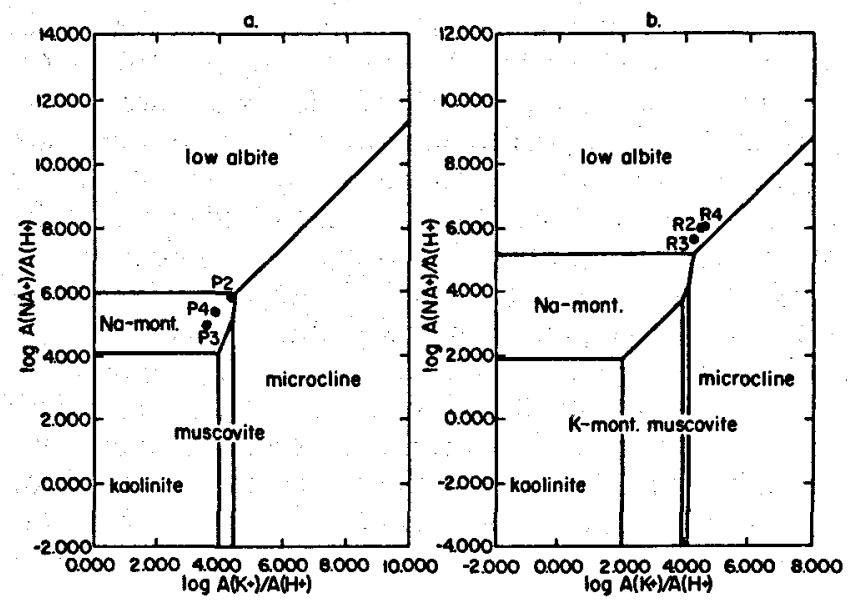

FIGURE 24 -COMPOSTTIONS OF HOT-WELL SAMPLES P2, P3, AND P4 PLOTTED ON MINERALSTABIITY DIAGRAM for system $\mathrm{HCl}-\mathrm{H}_{2} \mathrm{O}-\mathrm{Al}_{2} \mathrm{O}_{5}-\mathrm{K}_{2} \mathrm{O}-\mathrm{Na}_{2} \mathrm{O}$ $\mathrm{SiO}_{2}$ at $150^{\circ} \mathrm{C}\left(302^{\circ} \mathrm{F}\right)$ and $\log$ a $_{4} \mathrm{SiO}_{4}=-2.67=$ quartz saturation (a; phase boundaries after Helgeson and others, 1969); compositions of calculated geothermal reservoir waters R2, R3, and R4 plotted on mineral stability diagram for system $\mathrm{HCl}-\mathrm{H}_{2} \mathrm{O}-\mathrm{Al}_{2} \mathrm{O}_{3}-\mathrm{K}_{2} \mathrm{O}-\mathrm{Na}_{2} \mathrm{O}-\mathrm{SiO}_{2}$ at $250^{\circ} \mathrm{C}\left(482^{\circ} \mathrm{F}\right)$ and $\log { }^{a} \mathrm{H}_{4} \mathrm{SiO}_{4}=-2.11=$ quartz saturation (b; phase boundaries after Helgeson and others, 1969). 


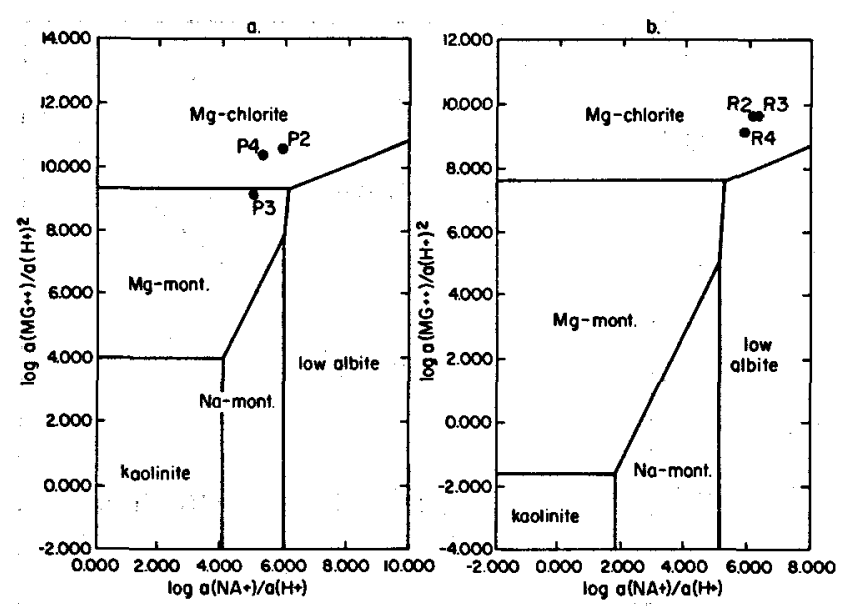

FIGURE 25-COMPOSTTIONS OF HOT-WELL SAMPLES P2, P3, AND P4 PLOTTED ON MINERALSTABLTTY DIAGRAM for system $\mathrm{HCI}-\mathrm{H}_{2} \mathrm{O}-\mathrm{Al}_{2} \mathrm{O}_{3}-\mathrm{MgO}_{2}-\mathrm{Na}_{2} \mathrm{O}$ $\mathrm{SiO}_{2}$ at $150^{\circ} \mathrm{C}\left(302^{\circ} \mathrm{F}\right)$ and $\log \mathrm{a}_{4} \mathrm{SiO}_{4}=-2.67=$ quartz saturation (a; phase boundaries after Helgeson and others, 1969); compositions of geothermal reservoir waters R2, R3, and R4 plotted on mineralstability diagram for system $\mathrm{HCl}-\mathrm{H}_{2} \mathrm{O}-\mathrm{Al}_{2} \mathrm{O}_{3}-\mathrm{MgO}-\mathrm{Na}_{2} \mathrm{O}-\mathrm{SiO}_{2}$ at $250^{\circ} \mathrm{C}\left(482^{\circ} \mathrm{F}\right)$ and $\log \mathrm{a}_{4} \mathrm{SiO}_{4}=-2.11=$ quartz saturation (b; phase boundaries after Helgeson and others, 1969).

alkali feldspar, probably albite. Fig. 25 , for the system $\mathrm{HCl}-\mathrm{H}_{2} \mathrm{O}-\mathrm{Al}_{2} \mathrm{O}_{3}-\mathrm{MgO}-\mathrm{Na}_{2} \mathrm{O}-\mathrm{SiO}_{2}$ at $150^{\circ} \mathrm{C}$ and $250^{\circ} \mathrm{C}$ $\left(302^{\circ} \mathrm{F}\right.$ and $\left.482^{\circ} \mathrm{F}\right)$ shows that magnesium montmorillonite and magnesium chlorite are likely phases in the mixed-water region, and that magnesium chlorite would be the stable phase in the deep-reservoir rocks. This result is consistent with the qualitative argument presented above for the indicated removal of $\mathrm{Mg}^{2+}$ and $\mathrm{HCO}_{3}{ }^{-}$from solution. As discussed above, all the sampled waters are saturated with respect to calcite. Therefore, at the higher temperature of the deep system, the waters will also be saturated with respect to calcite. Since the $\mathrm{Ca}^{2+} / \mathrm{Mg}^{2}+$ ratio is too high to stabilize dolomite, a magnesian calcite is the probable carbonate phase. $\mathrm{Mn}^{2+}$ concentration of $0.08 \mathrm{ppm}$ in water sample P3 suggests the possibility of manganoan calcite similar to the black manganoan calcite reported from late-stage vein systems in the Animas Valley and elsewhere in southwest New Mexico (Elston and others, 1973). Although the low-temperature sample waters are undersaturated with respect to anhydrite, the deep waters are saturated with respect to anhydrite because of the retrograde solubility of the calicum-sulfate phases in the temperature range of the Lightning Dock system.

Integrating the data of table 5 and figs. 23-25, possible alteration phases in the Lightning Dock system include magnesian calcite, montmorillonite, illite, chlorite, zeolites, alkali feldspar, quartz, chalcedony, anhydrite, fluorite, and iron oxides and sulfides. This assemblage is similar to that at the geothermal fields of the New Zealand volcanic zone, particularly Wairakei (Browne, 1978).

\section{Geometry and hydrodynamics of geothermal system}

STRUCTURAL CONTROL-Models of the Lightning Dock KGRA consider the geothermal reservoir to be situated more or less directly beneath the thermal anomaly of the hot wells (Jiracek and Smith, 1976;
Smith, 1978). This interpretation of the geometry of the geothermal system is based on the assumption that the 5 $\Omega-m$ isopleth on the electrical-resistivity map represents a conduitlike structure up which the geothermal fluids are ascending from the presumed reservoir. The conduit is presumed to be formed by the intersection of the ringfracture margin of the Muir cauldron with recently active basin-and-range faulting.

However, the linear trend in the geochemical isopleth diagrams of figs. 16-20 indicates that this interpretation is too simple. All the wells southwest of the hot wells are hydrologically upgradient from the thermal anomaly. Since their waters show the geochemical signature of deep-reservoir water, the main geothermal reservoir must be located southwest of the hot wells.

Gravity and electrical-resistivity data show anomalies that coincide very closely with the linear trend seen in the geochemical isopleths (Callender, 1981). The structure responsible for the northeast-trending geophysical anomalies is probably a high-angle fault or fault system. The trace of this fault or fault system may intersect very young, perhaps active, high-angle faults expressed in valley-fill sediments southwest of the hot wells along the western margin of the valley (Drewes and Thorman, 1980; S. G. Wells, University of New Mexico, personal communication, 1980). The bedrock geology of the western margin of the Animas Valley, southwest of the hot wells, is highly complex and poorly understood. There is a good possibility that one or more cauldron margins are buried by the valley fill (Deal and others, 1978) and that the bedrock has high fracture permeability. The buried northeast-trending fault in the valley would provide a conduit for small amounts of the deepreservoir fluid to leak into the shallow aquifers that are sampled by the wells southwest of the hot wells. Since the Animas Valley fault roughly coincides with the ringfracture zone of the Muir cauldron over a considerable distance, the proposed northeast-trending fault also explains the precise location of the thermal anomaly: the permeable conduit outlined by the $5 \Omega-m$ isopleth is formed by the intersection of two major fault systems with the margin of the ring-fracture zone.

The trace of the hypothetical fault intersects the basalt flow west of the village of Animas and is along the trend of the basaltic volcanism that extends from southeast Arizona into southwest New Mexico (fig. 8). While the 140,000-yr-old Quaternary flow on the west side of the Animas Valley is too old to be the source of heat for the Lightning Dock system, the coincidence of trends suggests that the ultimate heat source for the deep-reservoir geothermal fluid is deep-seated basalt [on the liquidus].

CONVECTION-A geothermal system that consists entirely of meteoric water in permeable rock must be in a state of forced convection. Cold, high-density water infiltrates along the boundaries of the system and circulates downward along interconnected channels to regions of higher temperature at depth. Hot, lower density water at depth rises through the permeable channels in the rocks, to be replaced by the cooler, denser water entering the system.

The subsurface flow paths in the Lightning Dock geothermal system must be complex. Geophysical modeling of the electrical-resistivity data shows that the body of 
hot water below the thermal anomaly is located in volcanic rocks of the ring-fracture zone of the Muir cauldron (Jiracek and Smith, 1976; Smith, 1978). Onedimensional modeling of a magnetotelluric survey indicates that a second, deeper reservoir exists (Jiracek, in Callender, 1981). The magnetotelluric results are equally consistent with the existence of the hightemperature reservoir to the southwest of the hot wells at a depth that again would place the reservoir below the valley-fill sediments.

Permeabilities of small specimens of the volcanic rocks in this area are probably very low. However, the bulk permeability of the fractured rock may be exceptionally high. Measured permeabilities on fractured welded tuffs from the Nevada Test Site, similar in lithology and tectonic setting to the Animas Valley samples, range from 5,000 to 30,000 millidarcies (Sorey and others, 1978). Field observations and the hydraulic behavior of shallow wells along the western margin of the valley indicate that, at least locally, even the shallow bolson fill has significant fracture permeability (S. G. Wells, personal communication, 1980). Even if the permeability of the rock decreases with depth, decreased density as a result of thermal expansion of the fluid, decreased viscosity of the hot water, and hightemperature dissolution of silica tend to counterbalance the decreasing permeability. Although the true intrinsic permeability of the consolidated reservoir rocks is not known, the permeabilities are probably sufficient to permit the movement of large volumes of water.

The driving force of a geothermal system is related to two separate factors: 1) differences in altitude between recharge and discharge areas, and 2) differences in density between the cold, downflowing and the hot, upflowing parts of the system. Ground-water hydrology of the Animas Valley suggests that relatively little recharge enters the valley at any given point from the immediately adjacent flanking ranges (Reeder, 1957). Therefore, the maximum elevation difference that can affect the recharge in the vicinity of the geothermal system is the difference of approximately $250 \mathrm{~m}(820 \mathrm{ft})$ in elevation between the southern end of the San Luis Valley near the Mexican border and the hot wells. The true recharge is a value integrated over the large area of the valley and the extremely low downward flow required by the recharge rate of $2.5 \mathrm{~mm} / \mathrm{yr}$ and the condition of steady flow (Reeder, 1957). Therefore, the effective head of cold water is substantially lower than the maximum, probably much closer to $50 \mathrm{~m} \mathrm{(160} \mathrm{ft),}$ equivalent to a pressure drive of $500 \mathrm{~Pa}$.

If the downward-flowing cold water in the system is assumed to have an average temperature of $45^{\circ} \mathrm{C}$ $\left(113^{\circ} \mathrm{F}\right)$ and a density of 0.99 , and the upward-flowing hot water has a temperature of $250^{\circ} \mathrm{C}\left(482^{\circ} \mathrm{F}\right)$ and a density of 0.79 , the pressure drive related to thermal ex-

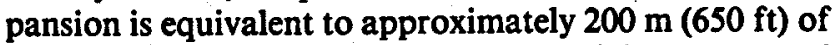
cold water for each $1,000 \mathrm{~m}(3,200 \mathrm{ft})$ of depth assumed for the temperature and density difference. For a geothermal reservoir at $1.5 \mathrm{~km}(0.9 \mathrm{mi})$ from which $250^{\circ} \mathrm{C}$ $\left(482^{\circ} \mathrm{F}\right)$ water rises to a mixing level at $0.5 \mathrm{~km}(0.3 \mathrm{mi})$ and then continues to rise at approximately $150^{\circ} \mathrm{C}$ $\left(302^{\circ} \mathrm{F}\right)$, the driving force related to thermal expansion is in the range of $2,000-2,500 \mathrm{~Pa}$.

These computations are crude, but they indicate that upward flow of hot water is apt to be much faster than downward flow of cold water and that the principal driving force in the geothermal system at Lightning Dock is probably related to density differences between the upward-flowing hot water and the downward-flowing cold water.

SUMMARY - Fig. 26 is a schematic block diagram that shows a hypothetical three-dimensional model of the geothermal system in the lower Animas Valley. The deep geothermal reservoir, containing hot water at approximately $250^{\circ} \mathrm{C}\left(482^{\circ} \mathrm{F}\right)$, is located in fractured volcanic rocks at approximately $1.5 \mathrm{~km}(0.9 \mathrm{mi})$ depth, approximately $15 \mathrm{~km}(9 \mathrm{mi})$ southwest of the hot wells. The ultimate source of the heat is deep-seated basalt [on or near the liquidus]. The reservoir is intersected by a northeast-trending high-angle fault system, along which small volumes of the convecting hot water rise and leak into shallow aquifers sampled by irrigation and domestic wells. Where the northeast-trending fault intersects the margin of the Muir cauldron ring-fracture zone and a basin-and-range fault, a highly permeable conduit is formed, and relatively large volumes of hot water move up to a zone of mixing at perhaps $0.5 \mathrm{~km}(0.3 \mathrm{mi})$. In this zone $250^{\circ} \mathrm{C}\left(482^{\circ} \mathrm{F}\right)$ water mixes with cold ground water in a ratio of approximately 1 part hot water to 3 parts cold water to produce a mixed water of $150^{\circ} \mathrm{C}$ $170^{\circ} \mathrm{C}\left(302^{\circ} \mathrm{F}-338^{\circ} \mathrm{F}\right)$. The mixed water continues to rise along a structurally controlled high-permeability conduit until it reaches the near-surface aquifer where it is sampled at the hot wells. In this shallow aquifer more mixing occurs, dispersing heat and deep-water chemical constituents in the pattern seen by Kintzinger (1956) and in many of the figures of this study.

\section{Conclusions on geochemistry}

The waters of Lightning Dock KGRA hot wells are interpreted as mixed waters containing approximately $25 \%$ deep geothermal fluid at approximately $250^{\circ} \mathrm{C}$ $\left(482^{\circ} \mathrm{F}\right)$. Although no thermal manifestation of the deep geothermal reservoir other than the hot wells is known, chemical and isotopic data suggest that chemically distinct hot water seeps into a shallow cold aquifer along a linear trend southwest of the hot wells. The deep water moves up and along a major northeast-trending fault or fault system from a reservoir located southwest of the hot wells, mixing with shallow, cold aquifer waters to produce the samples analyzed for this study. The heat source for the reservoir is probably basalt [ic magma].

The chemistry of the waters of the Animas Valley is produced by a variety of processes, including evaporation and boiling, water-rock interactions at high temperature, and mixing of solutions. Mixed-water lowtemperature ground waters have been modified by the dissolution of playa evaporites. The calculated reservoir chemistry suggests that the alteration phases associated with the high-temperature waters could include magnesian calcite, sodium and magnesian smectite, illite, calcium zeolite, chlorite, alkali, feldspar, quartz, chalcedony, anhydrite, fluorite, and iron oxides and sulfides. The model proposed here can be tested by a drilling program to study alteration mineralogy and to test the physical model of a high-temperature geothermal reservoir southwest of the Lightning Dock KGRA. 


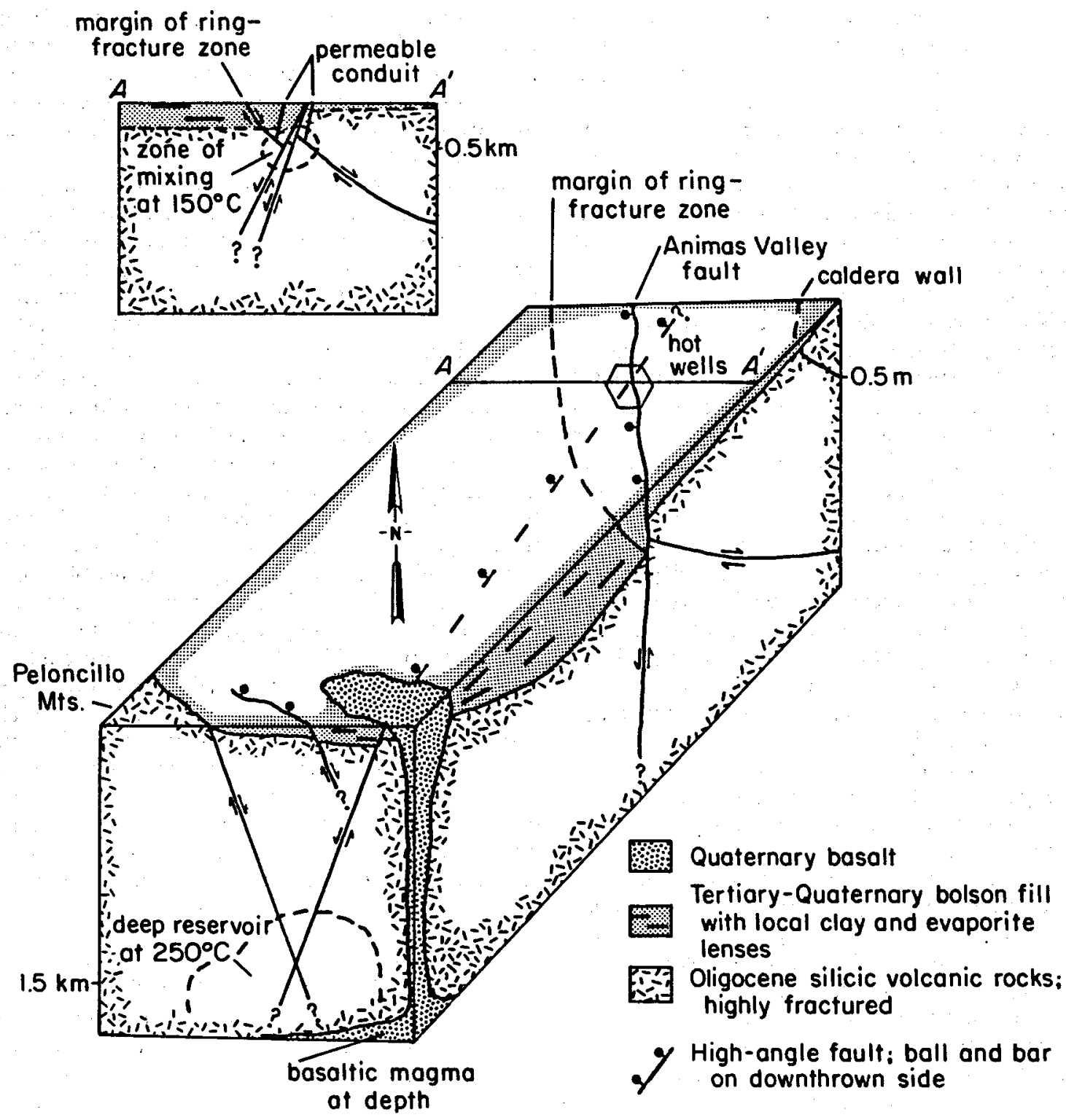

FIGURE 26-SChEMATIC BLOCK DIAGRAM OF GEOTHERMAL SYSTEM IN LOWER ANIMAS VALLEY. In this model, location of hot wells is structurally controlled by intersection of two major high-angle faults and margin of ring-fracture zone of Muir cauldron (Oligocene). 


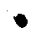

\section{- Conclusions concerning geothermal resources}

\section{Proposed geothermal system}

The geothermal waters of the Lightning Dock KGRA appear to have a complex origin. If our interpretations are correct, the present hot wells are at the northeast end of a deep fault zone that runs diagonally across the Animas Valley and is buried beneath valley fill. Water at a temperature of approximately $250^{\circ} \mathrm{C}\left(482^{\circ} \mathrm{F}\right)$ rises from depth, up and along this fault zone; the ultimate heat source may be deep-seated basalt near the solidus.

At the hot wells this water rises to shallow levels in a local conduit, probably controlled by the intersection of the ring-fracture zone of the Muir cauldron and the Animas Valley fault. Ground water in the Animas Valley moves from south to north, hence water rising to shallow levels near the hot wells fans out toward the north, becoming progressively cooler and more dilute. Chemical geothermometers indicate that the shallow reservoir temperature is $165^{\circ} \mathrm{C}\left(329^{\circ} \mathrm{F}\right)$; the silicaenthalpy mixing model suggests that it consists of $25 \%$ deep geothermal water and $75 \%$ cold ground water.

\section{Volume of geothermal reservoir}

Using all available geophysical data (mainly electrical-resistivity techniques and heat-flow measurements), Jiracek (in Callender, 1981) has made minimum estimates of the volume of the shallow geothermal reservoir. The estimated north-south extent is conservatively given as $2.5 \mathrm{~km}(1.5 \mathrm{mi})$, the east-west extent as $1.5 \mathrm{~km}$ $(0.9 \mathrm{mi})$, and the top and bottom of the aquifer as 25 and $200 \mathrm{~m} \mathrm{(80}$ and $650 \mathrm{ft})$. The thickness estimate is probably too high for the area of the hot wells, where bedrock was encountered at $26.5 \mathrm{~m}(86.9 \mathrm{ft})$, but is conservative for areas of thick valley-fill sediments nearer the axis of the valley. If the estimates are correct, the volume is $0.66 \mathrm{~km}^{3}\left(0.16 \mathrm{mi}^{3}\right)$, to which the volume of the proposed conduit near the hot wells can be added, giving a total of about $0.75 \mathrm{~km}^{3}\left(0.18 \mathrm{mi}^{3}\right)$. If the horizontal dimensions can be extended, the volume increases in proportion.

Assuming aquifer porosity of $20-25 \%$, volumetric specific heat of $0.65-0.70 \mathrm{cal} / \mathrm{cm}^{3}{ }^{\circ} \mathrm{C}$, reservoir temperature of $100^{\circ} \mathrm{C}\left(212^{\circ} \mathrm{F}\right)$, and mean annual temperature of $17^{\circ} \mathrm{C}\left(63^{\circ} \mathrm{F}\right)$, Jiracek (in Callender, 1981) calculated the heat content of the shallow reservoir at $2.1 \times 10^{17}$ joule $\left(2.0 \times 10^{14} \mathrm{Btu}\right)$. If high-temperature water exists at depth in the postulated fault zone southwest of the hot wells, the amount would, of course, be greater.

\section{Future prospects}

The Lightning Dock KGRA includes parts of the Pyramid Mountains and parts of the Animas Valley. Shallow geothermal hot water or steam, with temperatures of $165^{\circ} \mathrm{C}\left(329^{\circ} \mathrm{F}\right)$ or less, is most likely to be developed in the valley part, mainly north of the existing wells (fig. 6). Geochemical thermometry suggests that limited amounts of water as hot as $250^{\circ} \mathrm{C}\left(482^{\circ} \mathrm{F}\right)$ may exist at depth southwest of the hot wells, near an inferred buried fault zone. No indications of significant geothermal waters beneath the mountain part of the Lightning Dock KGRA have been ascertained from wells or surface geology.

Because both volume and temperature of the shallow geothermal reservoir are relatively low, the principal use for hot water and steam is likely to be for space heating, especially of greenhouses, and for crop drying and food processing. The present 5 acres of greenhouses can probably be expanded by a large factor. Landsford and others (1981) made a detailed economic analysis of the feasibility of using hot water from the Lightning Dock KGRA for precooking beef or for heating 5 acres of greenhouses for growing tomatoes or chrysanthemums.

The calculated shallow-reservoir temperature of $165^{\circ} \mathrm{C}\left(329^{\circ} \mathrm{F}\right)$ implies that no shallow vapor-dominated geothermal system is present in the Lightning Dock KGRA and that the use of geothermal energy for generating electricity is unlikely under present economic conditions. Only drilling can show whether deep $250^{\circ} \mathrm{C}$ $\left(482^{\circ} \mathrm{F}\right)$ water actually rises through a northeast-trending fault zone in the bedrock beneath the valley fill, southwest of the KGRA. No accurate information is available on the depth of valley-fill sediments, but they need not be excessively thick in all places. South and east of Cotton City and west of Animas, numerous hills of bedrock rise through the valley fill. The volume of the hypothetical $250^{\circ} \mathrm{C}\left(482^{\circ} \mathrm{F}\right)$ reservoir cannot be calculated with present information. The reservoir may be quite small, but the chance that the current geothermal anomaly is only a small leak in a large plumbing system is always present.

\section{Regional considerations}

Control of geothermal water by the intersection of a basin-and-range fault zone and a mid-Tertiary cauldron complex is not unique to the Lightning Dock KGRA. A similar case can be made for several other major geothermal anomalies in the southwest corner of New Mexico. For example, Mimbres Hot Springs, in Grant County, is at the intersection of the Mimbres Hot Springs fault and the inner caldera wall of the Emory cauldron (Elston and others, 1975). Faywood Hot Springs, also in Grant County, lies on or near the Silver City fault, on the northeastern margin of the Mangas graben (fig. 1) and directly next to an outer ring-fracture dome of the Emory cauldron. Lower Frisco Springs, in Catron County, can be interpreted as localized by the intersection of the southwest margin of the San Francisco Valley with the outer ring-fracture zone of the Bursum cauldron. The age, position, and very existence of the Gila Cliff Dwellings cauldron are controversial, but Ratté and Gaskill (1975) and Elston and others (1976) both show Gila Hot Springs, in Grant and Catron Counties, to be near the intersection of a basin-andrange fault zone (the northern side of the Gila Hot Springs graben of Ratté and Gaskill, 1975) and the inferred margin of the Gila Cliff Dwellings cauldron.

If these relationships are more than a coincidence, areas south of the Lightning Dock KGRA hold favorable prospects for future discoveries of geothermal hot 
water or steam. Erb (1979; as well as E. G. Deal and W. E. Elston in 1975-78) has resolved a nest of cauldron complexes that straddle the San Luis and southern Animas Valleys, as well as the San Simon-San Bernardino Valley immediately to the west in Arizona (Deal and others, 1978). Several of these cauldrons are larger than the Muir cauldron. Evidence for seismicity and volcanism in the recent geologic past becomes more impressive as one approaches the junction of New Mexico, Arizona, and Sonora, Mexico. The San Simon Valley around Rodeo, New Mexico, should be examined. It lies within the zone of Pleistocene basaltic volcanism that runs northeast from the San Bernardino volcanic field and is also within an Oligocene cauldron complex (the Rodeo cauldron of Deal and others, 1978).

Hot water has also been reported from the Playas Valley, east of the Pyramid Mountains. According to a rancher, Rex Kipp (personal communication, 1975), hot water was found in a well on the Muir (Kipp) Ranch, in NE $1 / 4$ NE $1 / 4$ sec. 10, T. 23 S., R. 17 W. A 12 -inch irrigation well on the Cooke farm near Lordsburg was also reported by Rex Kipp in 1975 to have yielded anomalously warm water (approximately $50^{\circ} \mathrm{C}$ at $365 \mathrm{~m}$; $120^{\circ} \mathrm{F}$ at $1,200 \mathrm{ft}$ ). 
Armstrong, A. K., Silberman, M. L., Todd, V. R., Hogatt, W. C., and Carten, R. B., 1978, Geology of the central Peloncillo Mountains, Hidalgo County, New Mexico: New Mexico Bureau of Mines and Mineral Resources, Circ. 158, $18 \mathrm{p}$.

Arnorsson, S., 1975, Application of the silica geothermometer in low temperature hydrothermal areas in Iceland: American Journal of Science, v. 275, p. 763-784

Ballmann, D. L., 1960, Geology of the Knight Peak area, Grant County, New Mexico: New Mexico Bureau of Mines and Mineral Resources, Bull. $70,39 \mathrm{p}$.

Bigeleisen, J., Perlman, M. L., and Prosser, H. C., 1952, Conversion of hydrogenic materials to hydrogen for isotopic analysis: Analytical Chemistry, v. 24, p. 1,356-1,357

Bornhorst, T. J., 1976, Volcanic geology of the Crosby Mountains and vicinity, Catron County, New Mexico: M.S. thesis, University of New Mexico, 113 p.

Browne, P. R. L., 1978, Hydrothermal alteration in active geothermal fields: Annual Review of Earth and Planetary Science, v. 6, p. 229-250

Callender, J. F., 1981, editor, Evaluation of geothermal potential of Rio Grande rift and Basin and Range province, New Mexico, final report: New Mexico Energy and Minerals Department and U.S. Geological Survey, 266 p.

Clark, K. F., 1970, Zoning, paragenesis, and temperatures of formation in the Lordsburg tistrict: New Mexico Geological Society, Guidebook 21st field conference, p. 107-113

Coffman, J. L., and von Hake, C. A., 1973, Earthquake history of the United States, revised edition (through 1970): National Oceanic and Atmospheric Administration, Pub. 41-1, 208 p.

Craig, Harmon, 1961, Isotopic variations in meteoric waters: Science, v. 133, p. 1,702-1,703

1963. The isotopic geochemistry of water and carbon in geothermal areas, in Nuclear geology of geothermal areas, E. Tongiorgi, editor: Pisa, Consiglio Nationale delle Ricerche, Laboratorio di Geologia Nucleare, p. 17-53

Dalyrymple, G. B., 1979, Critical tables for conversion of K-Ar dates from old to new constants: Geology, v. 7, no. 11, p. 558-560

Dane, C. H., and Bachman, G. O., 1965, Geologic map of New Mexico: U.S. Geological Survey, 2 sheets, scale 1:500,000

Deal, E. G., Elston, W. E., Erb, E. E., Peterson, S. L., Reiter, D. E., Damon, P. E., and Shafiqullah, M., 1978, Cenozoic volcanic geology of the Basin and Range province in Hidalgo County, southwestern New Mexico: New Mexico Geological Society, Guidebook 29th field conference, p. 219-229

Dellechaie, Frank, 1977, A geological and hydrogeochemical study of the Animas geothermal area, Hidalgo County, New Mexico: Geothermal Resources Council, Trans., v. 1, p. 73-75

Drewes, Harald, and Thorman, C. H., 1980a, Geologic map of the Steins quadrangle and the adjacent part of the Vanar quadrangle, Hidalgo County, New Mexico: U.S. Geological Survey, Misc. Inv. Series Map I-1220, scale 1:24,000 _ 1980b, Geologic map of the Cotton City quadrangle and the adjacent part of the Vana quadrangle, Hidalgo County, New Mexico: U.S. Geological Survey, Misc. Inv, Series Map I-1221, scale 1:24,000

Elder, John, 1976. The bowels of the Earth: London, Oxford University Press, 272 p

Ellis, A. J., and Mahon, W. A. J., 1964, Natural hydrothermal systems and expecimental hot water/rock Interactions: Geochimica et Cosmochimica Acta, 2.28, p. $1,323-1,357$

Elston, W. E., 1963, Geology and mineral resources of Hidalgo County, New Mexico: New Mexico Bureaul of Mines and Mineral Resources, Openfile Rept. (unpub.), 781 p.

1965, Mining districts of Hidalgo County, New Mexico: New Mexico Geological Society, Guidebook 16th field conference, p. 210-214
1968, Terminology and distribution of ash flows of the Mogollon-Silver City-Lordsburg region, New Mexico: Arizona Geological Society, Guidebook to Southern Arizona III, p. 231240

1978, Tertiary cauldrons and their relationship to mineral resources, southwestern New Mexico-a brief review: New Mexico Geological Society, Spec. Pub. 7, p. 107-113

Elston, W. E., Damon, P. E., Coney, P. J., Rhodes, R. C., Smith, E. I., and Bikerman, Michael, 1973, Tertiary volcanic rocks, Mogollon-Datil province, New Mexico, and surrounding region-K-Ar dates, patterns of eruption, and periods of mineralization: Geological Society of America, Bull., v. 84, no. 7, p. 2,259-2,274

Eiston, W. E., Erb, E. E., and Deal, E. G., 1979, Tertiary geology of Hidalgo Country, New Mexico-Guide to metals, industrial minerals, petroleum, and geothermal resources: New Mexico Geology, v. 1, no. 1, p. 1-6

Elston, W. E., Rhodes, R. C., Coney, P. J., and Deal, E. G., 1976, Progress report on the Mogollon Plateau volcanic field, southwestern New Mexico, No. 3-Surface expression of pluton: New Mexico Geological Society, Spec. Pub. 5, p. 3-28

Elston, W. E., Seager, W. R., and Clemons, R. E., 1975, Emory cauldron, Black Range, New Mexico-Source of the Kneeling Nun Tuff: New Mexico Geological Society, Guidebook 26th field conference, p. 283-292

Epstein, S., and Mayeda, T., 1953, Variation of O'" content of waters from natural sources: Geochimica et Cosmochimica Acta, v. 4, p. 213-224

Erb, E. E., Jr., 1979, Petrologic and structural evolution of ash-flow tuff cauldrons and noncauldron-related volcanic rocks in the Animas and southern Peloncillo Mountains, Hidalgo County, New Mexico: Ph.D. thesis, University of New Mexico, 286 p.

Flege, R. F.; Jr., 1959, Geology of Lordsburg quadrangle, Hidalgo County, New Mexico: New Mexico Bureau of Mines and Mineral Resources. Bull. 62, $36 \mathrm{p}$.

Fleischhauer, H. L., 1978, Summary of the late Quaternary geology of Lake Animas, Hidalgo County, New Mexico: New Mexico Geological Society, Guidebook 29th field conference, p. 283-284

Fournier, R. O., and Potter, R. W. II, 1979 , Magnesium correction to the Na-K-Ca chemical geothermometer: Geochimica et Cosmochimica Acta, v. 43, p. 1,543-1,550

Fournier, R. O., and Rowe, J. J., 1966, Estimation of underground temperatures from the silica content of water from hot springs and wet steam wells: American Journal of Science, v. 264, p. 685-697

Fournier, R. O., and Truesdell, A. H., 1973, An empirical Na-K-Ca geothermometer for natural waters: Geochimica et Cosmochimica Acta, v. 37, p. 1,255-1,275

1974, Geochemical indicators of subsurface temperature-Part II, Estimation of temperature and fraction of hot water mixed with cold water: U.S. Geological Survey, Journal of Research, v. 2, p. 263-270

Fournier, R. O., White, D. E., and Truesdell, A. H., 1974, Geochemical indicators of sub surface temperature--Part I, Basic assumptions: U.S. Geological Survey, Journal of Research, v. 2, p. 259-262

Garcia-Gutierrez, Carlos, and Garcia-Gutierrez, Luis, 1969, The manganese metallogenic province in the state of Chihuahua, Mexico: New Mexico Geological Society, Guidebook 20th field conference, p. 205-206

Gat, J. R., and Dansgaard, W., 1972, Stable isotope survey of the fresh water occurrences in Israel and northern Jordan rift valley: Journal of Hydrology, v. 16, p. 177-212

Gat, J. R., and Issar, Arie, 1976, Desert isotope hydrology - Water sources of the Sinai Desert: Geochimica et Cosmochimica Acta, v. 38, p. $1,117-1,131$

Gillerman, E. G., 1958, Geology of the central Peloncillo Mountains, Hidalgo County, New Mexico and Cochise County, Arizona: New Mexico Bureau of Mines and Mineral Resources, Bull. 57, 152 p.

Grim, P. J., Clark, J. M., and Morris, L. D., 1977 , Geothermal energy resources of the western United States: National Geophysical and Solarterrestrial Data Center, National Oceanic and Atmospheric Administration, scale 1:2,500,000

Helgeson, H. C., Brown, T. H., and Leeper, R. H., 1969, Handbook of theoretical activity diagrams depicting chemical equilibrium in geologic systems involving an aqueous phase at one atmosphere and $0^{\circ}$ to $300^{\circ} \mathrm{C}$ : San Francisco, FreemanCooper, 253 p.

Jiracek, G. R., and Smith, Christian, 1976, Deep resistivity investigations at two KGRAs in New Mexico-Radium Springs and Lightning Dock, in Tectonics and mineral resources of southwestern North America, S. A. Northrop and L. A. Woodward (editors): New Mexico Geological Society, Spec. Pub. 6, p. 71-76

Jiracek, G. R., Smith, Christian, Anders, M. E., Holcombe, H. T., and Gerety, M. T., 1977, Geophysical studies at Lightning Dock KGRA, Hidalgo County, New Mexico: Geothermal Resources Council, Trans., v. 1, p. 157-158

Kintzinger, P. R., 1956, Geothermal survey of hot ground water near Lordsburg, New Mexico: Science, v. 124, no. 3,223, p. 629-630

Landis, G. P., 1976, (co-investigators D. G. Brookins, J. F. Callender, W. E. Elston, G. R. Jiracek, A. M. Kudo, C. A. Swanberg, and L. A. Woodward), Final technical report of evaluation of geothermal potential of the Basin and Range province of New Mexico: U.S. Geological Survey, $117 \mathrm{p}$.

Landis, G. P., and Logsdon, M. J., 1980, Computer-based chemical and stable isotope modeling of geothermal systems in New Mexico: Energy Research and Development Program, Rept. to New Mexico Energy and Minerals Department, 83 p.

Landsford, R. R., Abernathy, G. H., Gollehon, N. R., Nelson, D. C., Chaturverdi, L. N., Cotter, D. J., Clevenger, T. S., Creel, B. J., Patterson, R. C., Monji, R. G., and Arras, M. R., 1981. Utilization of geothermal energy for agribusiness development in southwestern New Mexico: New Mexico Energy and Minerals Dept., New Mexico Energy Research and Development Program, Rept. EMD 78-2234, 168 p.

Lasky, S. G., 1938, Geology and ore deposits of the Lordsburg mining district, Hidalgo County, New Mexico: U.S. Geological Survey, Bull. 885, 62 p.

Lipman, P. W., 1976, Caldera-collapse breccias in the western San Juan Mountains, Colorado: Geological Society of America, Bull., v. 87, no. 10, p. $1,397-1,410$

Logsdon, M. J., 1981, The aqueous geochemistry of the Lightning Dock Known Geothermal Resource Area, Animas Valley, Hidalgo County, New Mexico: M.S. thesis, University of New Mexico, 239 p.

Lynch, D. J., 1978, The San Bernardino volcanic field of southeastern Arizona: New Mexico Geological Society, Guidebook 29th field conference, p. 261-268

Mariner, R. H., and Willey, L. M., 1976, Geochemistry of thermal waters in the Long Valley, Mono County, California: Journal of Geophysical Research, v. 81, p. 792-800

Marvin, R. F., Naeser, C. W., and Mehnert, H. H. 1978, Tabulation of radiometric ages-including unpublished fission-track ages-for rocks in southeastern Arizona and southwestern New Mexico: New Mexico Geological Society, Guidebook 29th field conference, p. 243-252

Mottl, M. J., and Holland, H. D., 1978, Chemical exchange during hydrothermal alteration of 
basalt by seawater-1. Experimental results for major and minor components of seawater: Geochimica et Cosmochimica Acta, v. 42, p. 1,103-1,115

Needham, C. E., 1937, Some New Mexico fusulinidae: New Mexico Bureau of Mines and Mineral Resources, Bull. 14, 88 p.

Plummer, L. N, Jones, B. F., and Truesdell, A. H., 1978, WATEQF - a FORTRAN IV version of WATEQ, a computer program for calculating chemical equilibrium of natural waters: U.S. Geological Survey, Water Resources Invest. 76-13,63 p.

Preslar, Tony, 1976, Geophysical investigations at the Lightning Dock KGRA:' Geological Society of America, Abs. with Programs, v. 8, no. 5, p. 619

Quaide, W. L., 1953, Geology of the central Peloncillo Mountains, Hidalgo County, New Mexico: M.S. thesis, University of California (Berkeley)

RattE, J. C., and Gaskill, D. L., 1975, Reconnaissance geologic map of the Gila Wilderness study area, southwestern New Mexico: U.S. Geological Survey, Misc. Inv. Series Map I-886, 2 sheets, scale 1:62,500

Reeder, H. O., 1957, Ground water in Animas Valley, Hidalgo County, New Mexico: New Mexico State Engineer's Office, Tech. Rept. No. 11, $101 \mathrm{p}$.

Renner, J. L., White, D. E., and Williams, D. L., 1975. Hydrothermal convection systems, in Assessment of geothermal resources of the United States-1975: U.S. Geological Survey, Circ. 726, p. 5-57

Rothrock, H. E., Johnson, C. H., and Hahn, A. D., 1946, Fluorspar resources of New Mexico: New Mexico Bureau of Mines and Mineral Resources, Bull. 21, 239 p.

Schwennensen, A. T., 1918, Ground water in the Animas, Playas, Hachita, and San Luis Basins, New Mexico: U.S. Geological Survey, WaterSupply Paper 442, $152 \mathrm{p}$.

Seager, W. R., 1973, Resurgent volcano-tectonic depression of Oligocene age, south-central New Mexico: Geological Society of America, Bull., v. 84 , no. 11, p. 3,611-3,626

Simpson, E. S., Thorud, D. B., and Friedman, Irving, 1972, Distinguishing seasonal recharge to ground water by deuterium analysis in southern Arizona, in World water balance: UNESCO, $v$. 3, p. 623-633

Smith, Christian, 1978, Geophysics, geology, and geothermal leasing status of the Lightning Dock KGRA, Animas Valley, New Mexico: New Mexico Geological Society, Guidebook 29th field conference, p. 343-348

Smith, R. L., and Bailey, R. A., 1968, Resurgent cauldrons: Geological Society of America, Mem. 116, p. 613-662

Sorey, M. L., Lewis, R. E., and Olmstead, F. H., 1978, The hydrothermal system of Long Valley caldera, California: U.S. Geological Survey, Prof. Paper 1044-A, 60 p.

Spiegel, Zane, 1957, Geology and ground water in Animas Valley, Hidalgo County, New Mexico: New Mexico State Engineer's Office, Tech. Rept. 11, p. $9-12$

Summers, W. K., 1965a, A preliminary report on New Mexico's thermal waters: New Mexico. Bureau of Mines and Mineral Resources, Circ. 80,41 p.

1965b, Chemical characteristics of New Mexico's thermal waters-a critique: New Mexico Bureau of Mines and Mineral Resources, Circ. 83, $27 \mathrm{p}$.

1465c, Geothermics-New Mexico's untapped resource: New Mexico Bureau of Mines and Mineral Resources, Circ. 98, 9 p.

1970, Geothermal prospects in New Mexico: Geothermics, Spec. Issue 2, v. 2, p. 1,0091,014

, 1972, Geothermics of New Mexico: Geothermal Resources Council, Proc., 1st Ann. Meeting, Spec. Rept. 1, p. 115-137

Summers, W. K., Ross, S. H., and Birdseye, H. S., 1969, Geothermics in North America-present and future: (unpub. paper), American Association Petroleum Geologists, Rocky Mountain Section, Annual Meeting, $17 \mathrm{p}$.

Swanberg, Chandler, 1978, Chemistry, origin, and potential of geothermal resources in southwestern Arizona: New Mexico Geological Society, Guidebook 29th field conference, p. 349-352

Taylor, H. P., Jr., 1974, The application of oxygen and hydrogen isotopes to problems of hydrother- mal alteration and ore deposition: Economic Geology, v. 69, p. 843-883

Thorman, C. H., and Drewes, Harald, 1978, Geologic map of the Gary and Lordsburg quadrangles, Hidalgo County, New Mexico: U.S. Geological Survey, Misc. Inv. Series Map I-1151, scale 1:24,000

Truesdell, A. H., 1976, Chemical evidence of subsurface structure and fluid flow in geothermal systems, in Proceedings of the 1974 International Symposium on Water-Rock Interactions: Praha, Ustredni Ustav Geologicky, p. 250-257

Truesdell, A. H., and Fournier, R. O., 1977, Procedure for estimating the temperature of a hotwater component in a mixed water by using a plot of dissolved silica versus enthalpy: U.S. Geological Survey, Journal of Research, v. 5, p. 49-52

Truesdell, A. H., Nathenson, M., and Rye, R. O., 1977, The effects of subsurface boiling and dilution on the isotopic compositions of Yellowstone thermal waters: Journal of Geophysical Research, v. 82, p. 3,694-3,704

Van Devender, T. R., and Spaulding, W. F., 1979, Development of vegetation and climate in the southwestern United States: Science, v. 204, p. 701-710

Walther, J. V., and Helgeson; H. C., 1977. Calculation of the thermodynamic properties of aqueous silica and the solubility of quartz and its polymorphs at high pressure and temperature: American Journal of Science, v. 277, p. 1,315-1,351

Wells, S. G., 1977, Geomorphic controls of alluvial fan deposition in the Sonoran Desert, southwestern Arizona, in Geomorphology in arid regions, D. O. Doehring, editor: Fort Collins, Colorado, Colorado State University, Pub. in Geomorphology, p. 27-50

White, D. E., 1957, Magmatic, connate, and metamorphic waters: Geological Society of America, Bull., v. 68, p. 1,659-1,682

Williams, Howel, 1941, Calderas and their origin: University of California (Berkeley), Pub. in Geological Sciences, v. 25, D. 239-246

Zeller, R. A., Jr., and Alper, A. M., 1965, Geology of the Walnut Wells quadrangle, Hidalgo County, New Mexico: New Mexico Bureau of Mines and Mineral Resources, Bull. 84, 105 p.

\section{Contents of Pocket}

\author{
Geologic map \\ Table 2-Chemical analyses
}

$\begin{aligned} & \text { Type faces: } \begin{array}{l}\text { Text in 10-pt. English Times leaded one point } \\ \text { References in 7-pt. English Times, leaded one point } \\ \text { Main heads in 24-pt. English Times } \\ \text { Subheads in 14-pt. and 12-pt. English Times }\end{array} \\ & \text { Presswork: } \quad \begin{array}{l}\text { Miehle Single Color Offset } \\ \text { Harris Single Color Offet }\end{array} \\ & \text { Binding: } \quad \begin{array}{l}\text { Saddlestitched with softbound cover } \\ \text { Paper: } \quad \begin{array}{l}\text { Cover on Coronado Horizon Mad Yellow } \\ \text { Text on 60-lb. white offset }\end{array} \\ \text { Ink: } \quad \begin{array}{l}\text { Cover-Black } \\ \text { Text-Black }\end{array}\end{array} \\ & \text { Press Run: } 750\end{aligned}$




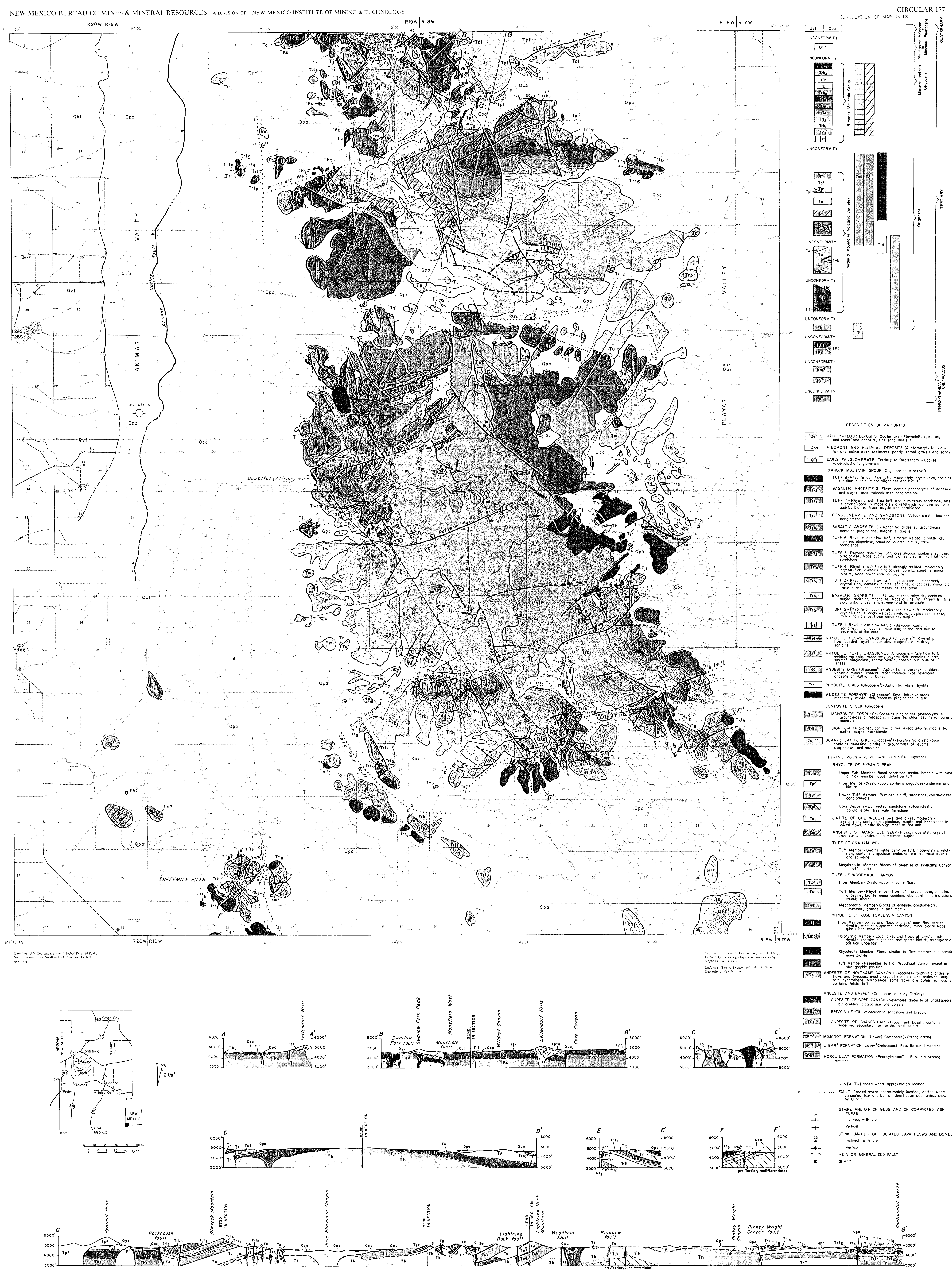

GEOLOGIC MAP OF SOUTHERN PART OF PYRAMID MOUNTAINS, HIDALGO COUNTY, NEW MEXICO

Edmond G. Deal and Wolfgang E. Elston 